\title{
WestVirginiaUniversity
}

THE RESEARCH REPOSITORY @ WVU

Graduate Theses, Dissertations, and Problem Reports

2008

\section{Understanding the motivations of Ghanaian bureaucrats}

Christine Naa Norley Lokko

West Virginia University

Follow this and additional works at: https://researchrepository.wvu.edu/etd

\section{Recommended Citation}

Lokko, Christine Naa Norley, "Understanding the motivations of Ghanaian bureaucrats" (2008). Graduate Theses, Dissertations, and Problem Reports. 4398.

https://researchrepository.wvu.edu/etd/4398

This Dissertation is protected by copyright and/or related rights. It has been brought to you by the The Research Repository @ WVU with permission from the rights-holder(s). You are free to use this Dissertation in any way that is permitted by the copyright and related rights legislation that applies to your use. For other uses you must obtain permission from the rights-holder(s) directly, unless additional rights are indicated by a Creative Commons license in the record and/ or on the work itself. This Dissertation has been accepted for inclusion in WVU Graduate Theses, Dissertations, and Problem Reports collection by an authorized administrator of The Research Repository @ WVU.

For more information, please contact researchrepository@mail.wvu.edu. 
Understanding the Motivations of Ghanaian Bureaucrats

Christine Naa Norley Lokko

\author{
Dissertation submitted to the \\ Eberly College of Arts and Sciences \\ at West Virginia University \\ in partial Fulfillment of the requirements \\ for the degree of
}

\author{
Doctor of Philosophy \\ in \\ Political Science
}
Jeff Worsham, Ph.D., Chair
Donley Studlar, Ph.D.
John Kilwein, Ph.D.
Joe D. Hagan, Ph.D.
Christopher Plein, Ph.D.

Department of Political Science
Morgantown, West Virginia 2008

Keywords: Motivation, Civil Servants, Bureaucrats, Ghana, Security, Family, Public Service 


\section{ABSTRACT \\ UNDERSTANDING MOTIVATIONS OF GHANAIAN BUREAUCRATS \\ Christine Naa Norley Lokko}

This study examines the factors that affect the work performance of Ghanaian bureaucrats. Three decades ago Robert Price (1975) examined the impact that kinship ties had on the motivation of Ghanaian bureaucrats. He found that Ghanaian bureaucrats behaved in particularistic fashions as opposed to acting in a universalistic manner, suggesting kinship was a major determinant of bureaucratic routine. This study followed the work of Price by replicating his mix of interviews and surveys, with the addition of questions that incorporate recent work on bureaucracy that suggest motivation involves a mix of solidary, functional, and pecuniary preferences (Brehm and Gates, 1997; Golden 2000). Utilizing a mix of interviews and surveys of public servants from the Civil Service and the Ghana Education Service, I find the motivation of Ghanaian bureaucrats involves pecuniary, solidary and functional preferences as well as kinship ties. 
Dedication

To Daniel and Zephan Richter,

The men in my life. 


\section{ACKNOWLEDGMENTS}

I would like to express gratitude to my committee, especially my chair and graduate advisor Dr. Jeff Worsham, who guided me in my doctoral journey, supervised my research, was extremely patient with me and gave me great editorial advice. I appreciate the support and guidance of Dr. Donley Studlar who was always prompt with reviewing submissions and constantly demonstrated his concern about career options after school. His advice and support were invaluable. I am grateful to Dr. Susan Hunter who guided me as I fumbled through SPSS.

My parents, Christian Barnor Lokko and Beatrice Abla Lokko, have been a major source of inspiration. They have always had high expectations of me and taught me that I can be whatever I want to be as long as I believed in myself and worked hard. I am also grateful for my mum's help in administering the questionnaires to public servants in the Ghana Education Service.

I appreciate the help of my sister, Leticia Lokko who walked with me in the hot sun and was my support as I solicited respondents in the streets of Accra. In her company my fear of rejection was reduced considerably. I cannot forget my sister, Juliana Lokko who kept checking on me to see how well the data collection process was going.

I could not have gotten this far without my cousin and friend, Dr. Kezia Dzifa Awadzi. She willingly shared her experiences from her doctoral studies with me and her prayers, and humorous chats gave me much inspiration and reduced some of the stress.

I recognize the contributions made by Mr. Akwei Allotey who provided me with invaluable information about the Ghana Civil Service and without whose help I would have been unable to identify respondents in the Civil Service. I am deeply grateful to my Aunt, Ms. Augustina Lokko who introduced me to Mr. Allotey. I am eternally grateful to Dr. Joseph Ayee who reviewed my questionnaires and administered a substantial portion of the surveys on my 
behalf at the University of Ghana. I am also grateful to my uncle, Dr. Winston Awadzi who reviewed my pre-test questionnaires with his expert eye.

I would also like to acknowledge the following persons who were a source of encouragement and inspiration to me: Zoa Williams and Maximo Martinez. They were faithful prayer partners throughout my academic journey.

I also want to acknowledge the help of all who read and re-read my dissertation and helped me identify errors I had missed: Mrs. Beatrice Lokko, Mr. Cyprien Lokko and Dr. Kezia Awadzi.

I am deeply grateful for the financial and emotional support offered by the Office of Social Justice throughout my doctoral program. I particularly want to express my sincere gratitude to Jennifer McIntosh, Charles Morris and Rochelle Hutchins.

Finally, I acknowledge the grace of the Almighty God and the presence of the Holy Spirit. When I felt I had hit a wall and could not go any further, His mighty hand led me and showed me how much more I was capable of. Truly, I can do all things through Christ who strengthens me. 


\section{TABLE OF CONTENTS}

page

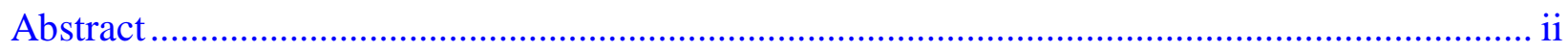

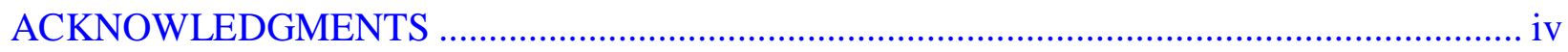

TABLE OF CONTENTS ............................................................................................ vi

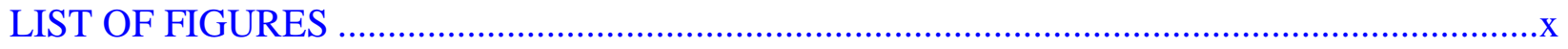

Figure 2-1. Organizational Chart of GES and Ghana Civil Service........................

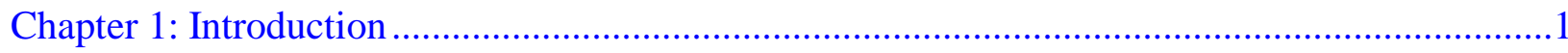

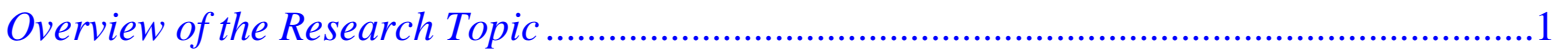

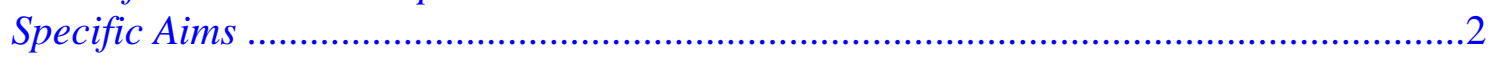

Chapter 2: Administrative and Political History ................................................................4

The Colonial Civil Service ..............................................................................................4

The Africanization Process................................................................................ 4

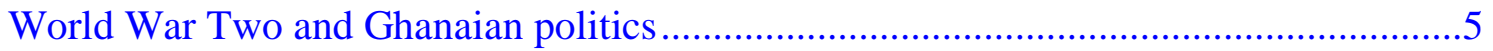

Post-Independence Politics and Its Impact on the Civil Service ........................................... 9

First Republic: Nkrumah and the Civil Service ...................................................9

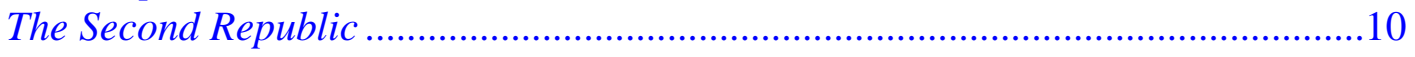

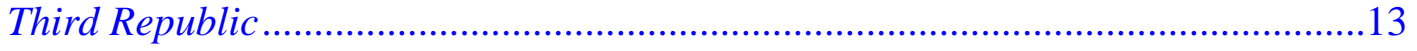

The Fourth Republic................................................................................. 14

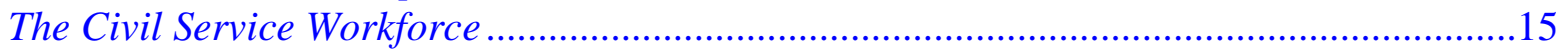

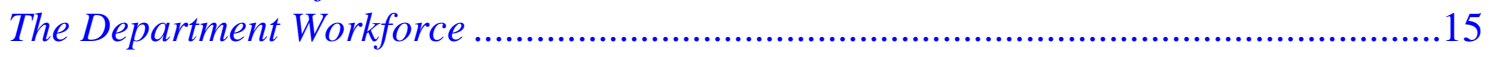

The Ministry of Education and the Ghanaian Education Service .........................................17

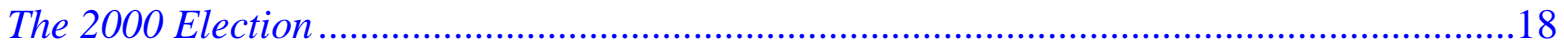

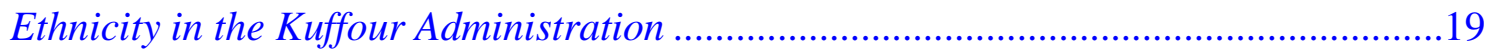

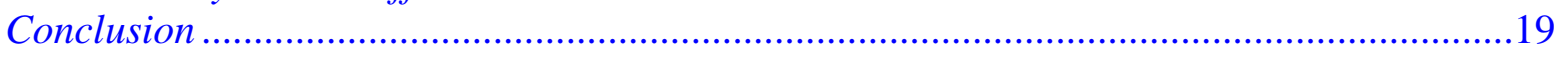

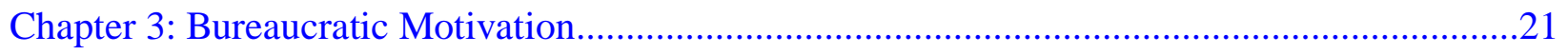

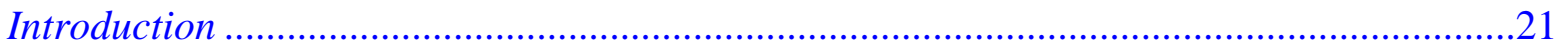

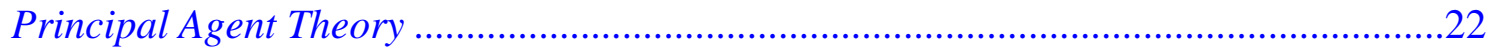

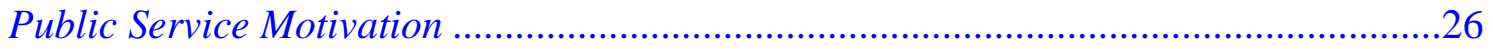

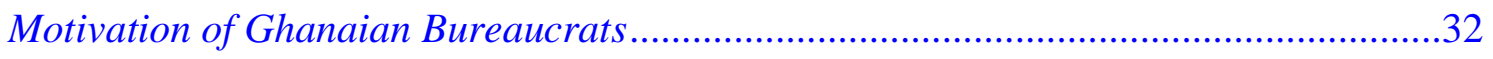

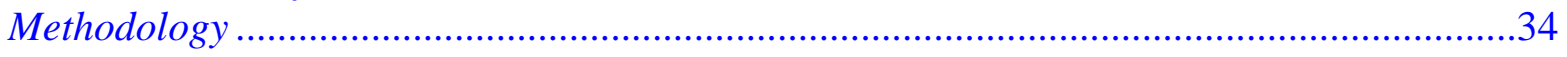

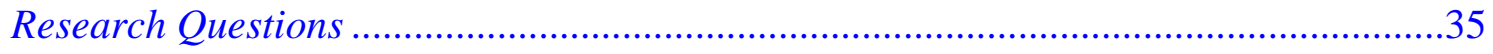

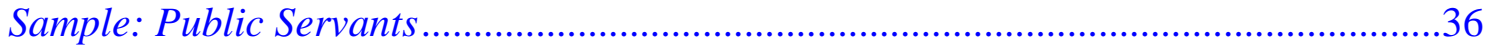

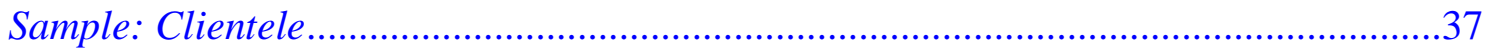




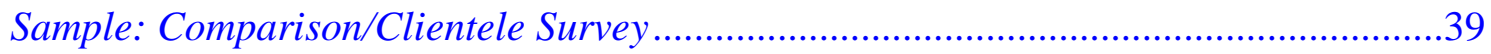

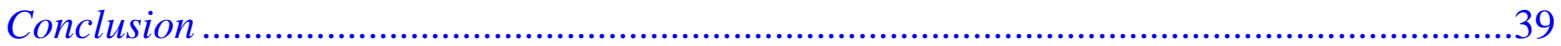

Chapter 4: Results of the Public Servant Survey ..................................................................42

Characteristics of Public Servant Respondents ...................................................................42

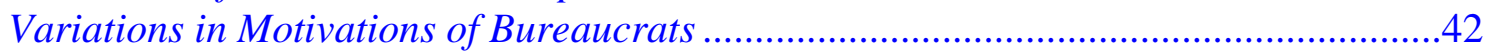

Public Service Motivation ........................................................................................52

Perceptions of Public Servants about Expectations from Significant Others .................58

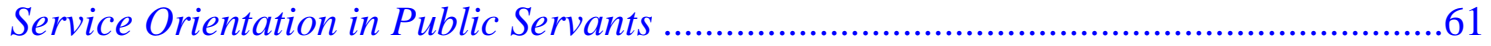

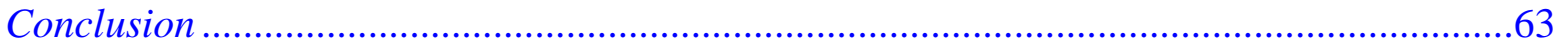

Chapter 5: Results of the Clientele Survey ........................................................................64

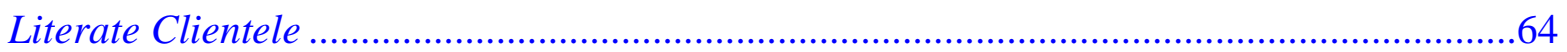

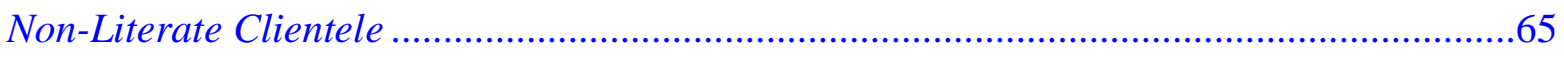

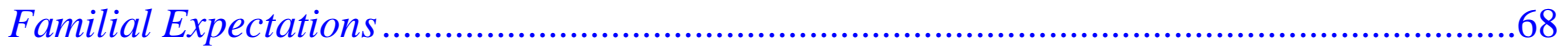

Examining the Existence of Service Orientation among Ghanaians ....................................73

Corruption in Ghana ...............................................................................................81

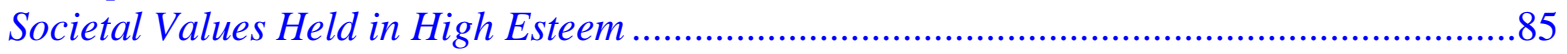

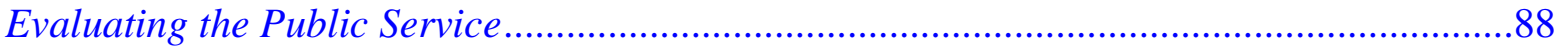

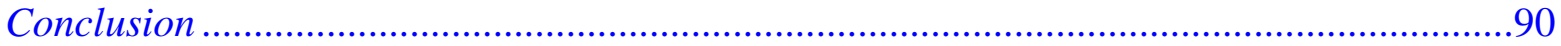

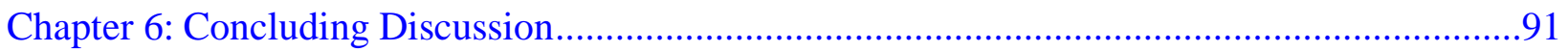

Similarity of Ghanaian Public Servants to their American Counterparts ............................91

Public Service Motivation..............................................................................................92

Comparing Responses of Public Servants to Clients........................................................95

Comparing the non-literate and Literate Clientele .........................................................95

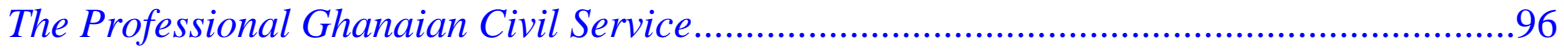

Future Research ......................................................................................................97

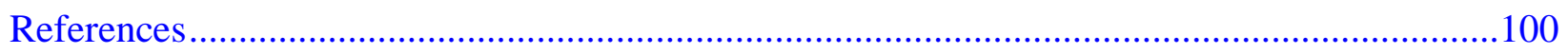

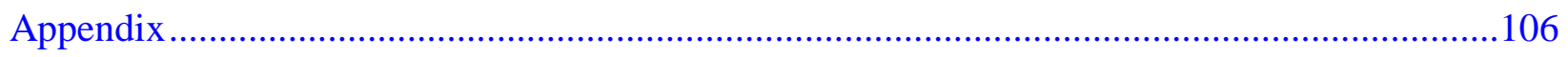

Important Dates in Ghanaian Political History .......................................................... 106

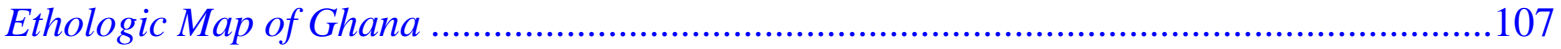

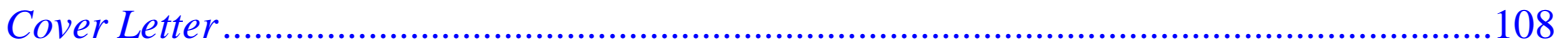

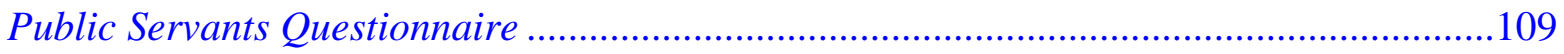

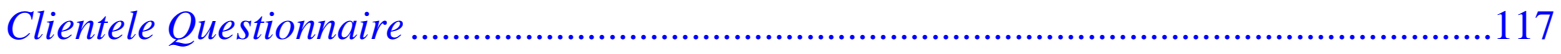

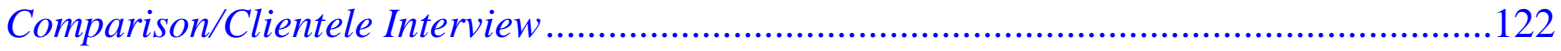




\section{LIST OF TABLES}

$\underline{\text { Table }}$

page

Table 4-1. Characteristics of Public Servant Respondents (Percent)

Table 4-2. Percentage of Public Servants with Supervisory Responsibilities

Table 4-3. Supervisor's Response to Slacking Employee-Comparing American and Ghanaian Bureaucrats (Percent).

Table 4- 4. Perceptions of Public Servants about their Work Performance (Percent)................46

Table 4-6. Impact of Peers on Work Performance of Public Servants (Percent)

Table 4-7. Impact of Functional Motives on Work Performance of Ghanaian Public Servants (Percent).....

Table 4-8. Impact of Type of Organization \& Ruling Government on Working Style

(Percent).

Table 4-9. Which of the Following Aspects of a Job are Attractive to Respondents?

Table 4-11. Suggestions from Public Servants for an Intelligent Young Man (Percent) .............56

Table 4-12. Conditions under which Public Servant Might Leave Public Service (Percent) ........57

Table 4-13. Head of Department's Decision Concerning Cousin's Transfer (Percent)

Table 4-14. Expectations of Significant Others Regarding Head of Department's Decision to Transfer Cousin (Percent)

Table 4-15. Reaction of Significant Others if Head of Department Transfers Cousin to the North (Percent).

Table 4-15. Options Available to Clients in Need of Public Service (Percent)..........................62

Table 5-1. Characteristics of Literate Clientele ..................................................................65

Table 5-2. Characteristics of Non-Literate Clientele ..........................................................67

Table 5-3. Literate Respondents' Perceptions about Employment after Graduation (Percent).....68

Table 5-4. 2006 Respondents Prediction of Head of Department's Behavior (Percent) ..............70

Table 5-5. Family's Reaction if Head of Department Transfers Cousin to the North (Percent) ...71

Table 5-6. Respondents' Beliefs about Proper Orientation in the Client Role (Percent) .74 
Table 5-7. Non-literate Estimates of Their Probable Reaction to Bureaucratic Delays (Percent).

Table 5-8. Respondents' Evaluations of Alternative Methods of Doing Business at Government Offices: Comparison of Clientele Samples (Percent) .78

Table 5-9. Importance of Knowing an Important Man (Percent) ......................................................81

Table 5-10. Social Esteem and Organizational Corruption: Effect of Education ...........................83

Level of Respondent's Educational Background (Percent) ….....................................................83

Table 5-11. Respondent's Choice of Public Servant as Relative (Percent) ...................................85

Table 5-12. Qualities in Individuals that Ghanaians Respect (Percent) ………….........................87

Table 5-13. Respondent's Rating of Performance of Public Service (Percent).............................89

Table 5-14. Respondents' Perception about the Role of the Public Service/ Servants (Percent) 


\section{LIST OF FIGURES}

$\underline{\text { Figures }}$

Figure 2-1. Organizational Chart of GES and Ghana Civil Service........................ 16 


\section{Chapter 1: Introduction}

\section{Overview of the Research Topic}

Scholars of bureaucracy have debated whether bureaucrats work hard or are just lazy paper pushers. Scholars who believe bureaucrats work hard proceed further to suggest that some individuals are naturally imbued with certain characteristics or desires that make them lean toward public service work. This study examines motivations of bureaucrats in Ghana. What influences a bureaucrat's attitude to work? Do expectations of family and peers help us understand the behavior of bureaucrats on the job? What about bureaucrats' expectations of remuneration and fringe benefits? Do some bureaucrats possess innate characteristics that motivate them to serve the public?

This dissertation is motivated by two seminal studies-Price (1975) and Brehm and Gates (1998). Price suggested societies emerging from colonial rule lacked the two behavioral requirements of organizational effectiveness (i.e., "dependable role performance” and "spontaneous behavior"). In a study focused on Ghana, he found the manner in which bureaucracy was institutionalized and the Ghanaian socio-cultural environment, hampered bureaucratic integration into the local society (Price, 1975, p. 24). Price defined dependable role performance as the "ability and willingness of public personnel to carry out their assigned roles at some minimal level of quantity and quality" (Price, 1975, p. 24). Spontaneous behavior referred to the "presence of some level of innovativeness that motivates the employee to want to perform above and beyond the routine and mundane tasks assigned to him/her and spurs employee to take initiative" (Price, 1975, p. 24).

In terms of the manner in which bureaucracy was institutionalized, Price noted that it was accomplished in "status" but not in "role". In other words, aspects of the institutional transfer

that challenged societal norms were rejected. For instance, Ghanaian society did not permit "role 
differentiation" (i.e., separation of personal roles from official ones) (Price 1975, p. 38). Price posited that the public servant in Ghana faced challenges when choosing to behave in a universalistic manner because his or her family would appropriate the public servant's position as well as the benefits that came with it.

Price also argued that clients in transitional societies lacked a service orientation which he defined as "the individual's ability to see him or herself as a citizen and to expect the rights that a state accords to its citizens" (Price, 1975, p. 132). According to Price, this lack of service orientation stems from 1) low income conditions 2) lack of national and political integration and 3) lack of role differentiation that forced clients to view public servants as personally possessing the power and services attached to their offices (Price, 1975, p. 132).

Price noted, however, that the higher the respondent's level of education or even in some cases the higher the level of education of the respondent's parents, the more likely the respondent was to possess a service orientation and to expect universalistic behavior from the bureaucrat. This study followed the work of Price by replicating his mix of interviews and surveys, with the addition of questions that integrate topical work on bureaucracy (Brehm and Gates, 1998) suggesting that motivation involves a blend of solidary, functional and pecuniary preferences.

Brehm and Gates (1998) challenged traditional perceptions about the principal agent relationship. They challenged earlier studies that credited supervision for optimum performance and maintained that a variety of motivations determined how bureaucrats do their job. A detailed discussion of these motives is undertaken in Chapter 3.

Specific Aims

This study has three main goals: a) To determine whether the variations in motivations that Brehm and Gates identified among American federal bureaucrats are present among Ghanaian bureaucrats. b) To examine if public service motivation has taken root among public 
servants in Ghana. c) To observe the extent to which expectations of significant others mirror responses in Price's study.

This study is organized into six chapters. Chapter 2 places the study in a historical and political context. The chapter begins with a discussion of the struggles of the Ghanaian political elite during the colonial period for the attainment of independence. The discussion follows with an examination of the literature on post colonial Ghanaian politics. The chapter also examines the Ghanaian Public Service from its inception to the present. Chapter 3 is in two main parts. The first section reviews the literature on public service motivation while the latter section discusses the methodology employed for this study. Chapter 4 analyzes responses from Ghanaian public servants and Chapter 5 discusses the findings from clients of the public service. The concluding chapter, Chapter 6 juxtaposes the responses of civil servants with those of their clients. It also discusses the implications of the findings and explores areas where future research on Ghanaian bureaucrats may focus. 


\section{Chapter 2: Administrative and Political History}

This chapter is a narrative of Ghana's administrative and political history. It is an account of how colonial, military and civilian regimes effected the bureaucratic institution. The chapter also discusses the role of ethnicity in Ghanaian social, political and administrative society and begins with an examination of the colonial civil service.

\section{The Colonial Civil Service}

Tiger (1963) credited 1830 as the beginning of Western government in Ghana, when the first English Governor, George Maclean introduced British patterns of government in the West African state. However, the British did not always follow the rules of bureaucratic practice in Ghana. Tiger (1963) described the colonialists as a club of bachelors who governed with little respect for bureaucratic norms. The Colonial Service was the political and administrative government in the Gold Coast and for that reason it failed the requirement of neutrality that Weber advocated. It was therefore not a total replica of the British civil service. Tiger (1963) argued that this dual role that the Colonial Service played has caused the African civil servant to misunderstand the neutral role that the civil service has to play vis-à-vis the political leadership. Ironically, in cases where public servants attempted to be neutral, they were misconstrued by the politicians as taking positions against them. It was in 1951 when ministerial government was introduced in Ghana in an attempt to remove the political aspect of the public servants career to this new branch of government. The introduction of ministerial government also enabled the colonial administration to diversify the composition of the government.

\section{The Africanization Process}

Africanization, the process whereby expatriate officers in the colonial civil service were replaced by Africans began under Guggisberg (1919-1927) who served as the first governor of 
the Gold Coast. He engineered the building of Achimota High School with the goal of producing trained Ghanaians who would later take up employment in the public service.

A rapid Africanization process was delayed for a number of reasons. One was that the colonialists had preset attitudes about the character/persona of what a senior servant should be and what kind of qualifications he should have. For starters it was preferred that he was an Oxford or Cambridge graduate. The reality was that very few of the Africans had any college degrees and fewer still graduated from Oxford or Cambridge (Tiger, 1963). The Africans saw this educational requirement as a way to keep them out of senior positions in the public service.

The rate of Africanization increased in the 1950's in response to demands for independence. Tiger (1963) noted that the colonialists saw the Africanization program as a means of co-opting potentially bothersome educated Africans into government in an effort to reduce excessive criticism of the regime. Furthermore, events in the international arena inadvertently helped to further the political aspirations of the African intelligentsia.

World War Two and Ghanaian politics

Events during World War II placed the Gold Coast and other African colonies in a strategic position. When Italy switched to the Nazi side, Britain could no longer use the Mediterranean to access the Far East. In addition, France's defeat meant that British colonies were surrounded by potential enemy territory thereby making Gold Coast airfields strategically important (Bourret, 1960; Dzorgbo, 1998). For the country to be sufficiently responsive to war requirements, harbors, airfields and internal communication systems were improved. Substantial finances were remitted to Britain from the Gold Coast to aid her in the war and around 70,000 indigenes were recruited for the war effort. The financial and manpower strain this placed on the Gold Coast coupled with high living costs, greatly displeased the masses. Their only consolation 
was in the administration's assurance that conditions would ameliorate at the end of the war (Dzorgbo, 1998).

The ex-service men returned home at the end of World War II to discover to their disappointment that promises of remuneration and benefits made to them before joining the war were not forthcoming. The Ghanaian economy was doing poorly_inflation and unemployment were high and goods were scarce. Disenchantment with the colonial administration was at an alltime high. On February 28, 1948, tensions fomenting beneath the surface bubbled over, resulting in violent nationalistic riots against colonial rule that culminated in twenty-nine deaths and over 200 injuries (Austin, 1970). The veterans, on a peaceful demonstration to the Governor's residence to voice their displeasure, were stopped midway by a British official who insisted they retrace their steps and ordered the British troops to fire at the Ghanaian soldiers when the latter refused. Two soldiers died and five were wounded. Contemporaneously, disorder broke out in the capital as citizens looted stores, rioted and released prisoners in the city's jails to protest the high prices and the government's unwillingness to improve the economic conditions. The colonial administration blamed the United Gold Coast Convention party (the local majority party) for the riots and detained the party's six leaders, popularly known in Ghanaian history as the Big Six: Dr. J. B. Danquah, Dr. Kwame Nkrumah, Obetsebi Lamptey, Ako Adjei, William Ofori Attah and Edward Akuffo-Addo.

The 1948 riots advanced the interests of the politically motivated Africans. In a report to the colonial administration the UGCC noted that the indigenes were not pleased with their marginalization in politics. The report recommended a parliamentary style democracy with a unicameral legislature. Members of the legislature were to be majority African. These reforms were to lead the country toward self-government. 
Dzorgbo (1998) posited that the war had psychological benefits for Africans. "For those who directly participated in the war, the war brought out the fears, evils and barbarism of the white man's civilization... a manifestation of the probable havoc that beliefs of racial superiority could wreck on humankind when carried to the extreme" (Dzorgbo, 1998, p. 111). The creation of the United Nations following World War II, with its Charter debunking colonialism, gave voice to African anti-colonial groups. Governor Burns, in an attempt to keep dissension under control, allowed the creation of an African elected majority in the Legislature in 1946. While it had little authority over policy, it did control the purse strings (Dzorgbo, 1998). In addition, two Gold Coasters from the local elites were nominated to the Executive Council, a move that impressed the Ghanaian elites and resulted in a moderation in their demands.

The 1948 riots also had a profound effect on the UGCC. It revealed that Nkrumah's goals and vision differed from that of the other UGCC members. The latter favored a gradual transition to independence while Nkrumah sought immediate independence. This led to his secession from the party to form the Convention People's Party (CPP) (Austin, 1970, p. 17).

Austin (1970) noted that the CPP was able to claim a large following because they appealed to the masses. Most of their members were elementary school graduates who were a more accurate representation of Ghana at the time as compared to the elite of the UGCC. According to Apter (1972) "one of the major appeals of the C.P.P. was its provision of new roles, new jobs, new sinecures for those barred by lineage or clan ties from positions of importance and for those from rural areas whose ideas, expectation and desires had gone beyond the local purview" (Apter, 1972, p. 309).

The CPP won the general elections of 1952, 1954 and 1956. Asante and Gyimah-Boadi (2004) reported that in the 1954 general elections, political parties were formed along regional 
and ethnic lines. For instance the Northern People's Party (NPP) was formed to ensure the just treatment of the Northern region. It worked closely with the Muslim Association Party (MAP). Other political parties were the Togoland Congress and the Anlo Youth Association, both championing interests of the Volta region.

Ethnicity in Ghana

Ghana, like most African countries, is an ethnically diverse nation. There are approximately 100 linguistic groups in Ghana. The major ethnic groups are the Akan, Ewe, Mole-Dagbane, Guan, and Ga-Adangbe. Each of these groups has subdivisions that share a common cultural heritage, history, language, and origin. The Akan group speaks Akan, a language with many dialects such as Twi, Fante, Akuapem, Asante, Agona, Dankyira, Asen, Akyem Bosome, Kwawu, Ahafo, Nzema. Akan speakers are scattered across the nation. For instance Fante speakers come from the Central region while Asante speakers come from the Ashanti region. Other Akan speakers are located in the Western and Eastern regions of Ghana. Akans are the largest ethnic group in Ghana. The Ethnologic Map of Ghana (see Appendix) depicts the different regions in Ghana and the various language groups that may be found in those regions. That said, it must be noted that no part of Ghana is ethnically homogeneous. Urban centers are especially heterogeneous because of migration from the rural areas by those in search of employment. For the most part, the ethnic divisions have not resulted in severe conflicts. There have been isolated cases of ethnic tensions in parts of the country, however it has rarely served as a basis of a national conflict. Still, ethnic identities play an important role in Ghanaian politics. 
Nkrumah attempted to eliminate the role of ethnicity in politics when he introduced the 1957 Avoidance of Discrimination Act that banned all political organizations that were based on tribal, racial and religious identities. By this law, all parties became illegal. Members of the defunct political parties joined forces to form the United Party under the leadership of Kofi Abrefa Busia (Asante and Gyimah-Boadi, 2004).

\section{Post-Independence Politics and Its Impact on the Civil Service}

\section{First Republic: Nkrumah and the Civil Service}

Under Nkrumah's leadership, the civil service was greatly undermined, lacked effective organization and was in a constant state of low morale (Apter, 1972). Apter (1972) suggested that even though the civil service was characterized as lacking skilled employees, under Nkrumah, those with specialized educational technical skills were severely underutilized.

Kraus (1971) reported that the Ghanaian bureaucracy was subjected to institutional, ideological and personal controls. Nkrumah, suspicious of the institution's loyalty to the CPP party, implemented measures to undermine the service's devotion to colonial bureaucratic norms and infused it with a socialist developmental orientation. From 1960-1962 the CPP party directly intervened in the activities of the bureaucracy, often by taking over its functions. The Trade Union Congress (TUC), a labor union, with strong ties to the CPP party had a stranglehold over the Labor Department. In addition, party leaders were moved into senior positions in the bureaucracy and civil servants were pressured to become members of the CPP and TUC. Local party groups were formed in some ministries and were often headed by lower level civil servants whose task was to inform their superiors about the necessity for socialist development. A substantial number of departments were placed directly under the control of the president's office, allowing personal intervention of the latter. Price (1975) noted that the Nkrumah 
government abolished the Civil Service Commission to gain greater control over the service and often threatened to introduce a new disciplinary system into the civil service. Nkrumah's personal interest in Pan-African politics led to the establishment of an African Affairs Secretariat that was not under the Foreign Ministry but was staffed by civil servants and handled relations with African states.

By the early 1960s disagreements had arisen among the leadership of the CPP about the party's future direction. Nkrumah wanted the party to champion the pan Africanist cause and socialist economic policies. This resulted in some members of the party being expelled from the party. In 1962, there was an assassination attempt against Nkrumah, followed by more expulsions and arrests. After the 1962 incident, the leadership became more centered on the personality of Nkrumah as the government moved toward a one-party state (Azikiwe, 2007). The First Republic ended in 1966 with the overthrow of Nkrumah in a coup d'état, led by Colonel Kotoka. The plotters accused Nkrumah and the CPP of corruption that had rendered the country bankrupt.

\section{The Second Republic}

The Second Republic began in 1969 when the Progress Party (PP) led by Kofi Abrefa Busia came to power through democratic elections. Busia did not look to his party as a resource for governance but rather to traditional authorities, local elected officials and the civil service (Apter, 1972, p. 411). By extension, his government discriminated against the youth and workers, groups that had previously enjoyed a prominent role under Nkrumah. Apter (1972) posited that Busia's government's marginalization of these groups was so pervasive that "the memory of the worst excesses of the Nkrumah regime began to fade from memory and a more charitable view of Nkrumah or a certain nostalgia for past glories could be discerned" (1972, p. 413). 
Busia's goal for the civil service was to make it more efficient, autonomous and accountable. Busia's plan for achieving these goals was to purge the civil service by first dismissing more than five hundred career bureaucrats. This decision appeared to be ethnically motivated as none of the dismissed bureaucrats were from Busia's tribe (i.e., Akan). In addition to this politically unpopular action, Chazan (1983) reported that Busia's tenure produced a more political civil service. His regime was unable to improve the economic condition, creating a campaign platform for another military action led by General Ignatius Acheampong in 1972 (Chazan, 1989).

During Acheampong's reign under the National Redemption Council (NRC which later became the Supreme Military Council-SMC) Ghana experienced the worst economic downturn to date (Austin, 1985; Shillington, 1992). Civil disorder was on the rise and the administration found it difficult to govern effectively (Chazan, 1983, p. 1). In 1978, Acheampong attempted to implement "Union Government" (UNIGOV), a no-party constitution. The college students, who led the opposition against UNIGOV went on strike to protest Acheampong's regime. Professional groups such as lawyers, professors, and doctors, along with the Christian Council (an association of church leaders) asked for his resignation (Shillington, 1992). Acheampong submitted the UNIGOV proposal to a referendum and when at the end of the polling day he realized UNIGOV would not pass, he ordered polling officials to transport ballots to regional centers rather than count them at individual polling stations. The Chief Justice was fired for declaring this novel move as illegal and warrants were served for his arrest. The Acheampong government, in a public announcement, stated that the UNIGOV proposal had won the referendum. 
Under the Acheampong government the military worked hard to solidify its alliance with the civil service. In order to buy their loyalty, Acheampong promised to rehire the civil servants that Busia dismissed and offer them better terms of service. He appointed upper level bureaucrats to advisory positions and promised to protect the organization's autonomy. The operational autonomy of ministries within the civil service was strengthened and decision-making capabilities were devolved to some ministries. The government maintained control by reshuffling ministers or reorganizing departments, severely affecting departmental efficiency. Though the Acheampong regime solidified the bureaucratic-military alliance, it failed in effectively implementing policies, projects were poorly funded and corruption continued as expulsions of top level bureaucrats failed to nullify malpractices at the lower levels of the organization.

To salvage their image, another group of military officers led by General Akuffo forced Acheampong to resign (Shillington, 1992). Akuffo's government, known as SMC II, made few changes to the membership or the policies of the SMC. Akuffo intended to stick with the noparty concept until a new constitution could be put in place. General Akuffo's economic policies, primarily the devaluation of currency and the change to new currency notes, resulted in a wealthy minority making huge profits. The June 4, 1979 coup led by Lieutenant Jerry John Rawlings of the Armed Forces Revolutionary Council (AFRC) toppled Akuffo's regime. According to Shillington (1992) it was a period when the masses and the military were disenchanted with the senior military officers. As Shillington (1992) noted,

A large body of students from the University of Ghana marched from Legon to Burma Camp waving posters which demanded: 'Firing squad for nation wreckers' and 'Let the blood flow!'. The primary target was Acheampong... Significantly, there was no outright condemnation of the executions by Church, media, lawyers or other professional bodies. Most Ghanaians seemed to have accepted that some blood-letting was inevitable in the circumstances (p. 52-53). 
Generals Acheampong, Afrifa and Akuffo were executed by the Rawlings' government. Rawlings later announced that in the future individuals accused of corruption were going to face long term prison sentences rather than executions.

Rawlings brought the civil service organization more directly under government control (Chazan, 1983). In 1979 he fired heads of all ministries and several government officials were charged with corruption. The Rawlings regime eliminated top level positions such as the senior principal secretary and supervising senior secretary. Lower level members of the bureaucracy who appeared to support the Acheampong's regime were also dismissed. The AFRC fuelled class antagonisms by supporting the proletariats against the elites. The AFRC, which later became the PNDC, created organizations such as the People's Defense Committees (PDCs) and Workers' Defense Committees (WDCs) later referred to as Committees for the Defense of the Revolution (CDRs). They were intended to be associations of popular power and initially excluded elite membership. These groups had the objective of guarding against corruption, the abuse of power, social injustice, among other behaviors that discriminated against the masses (Library of Congress, 2008). The CDRs were promoters of the revolution-the attempt to bring “power to the people." Every government agency was expected to have a CDR which was headed by lower level employees and served as watchdog committees-keeping a check on upper level executives. Management boards were required to have a CDR member on their boards.

\section{Third Republic}

On September 24, 1979, the AFRC handed over power to the Peoples National Party (PNP) led by Hilla Limman (Nugent, 1995). This marked the beginning of the Third Republic. While in power, Limann reasoned that to ensure his longevity, Rawlings and the AFRC had to be 
removed. Limann's government offered study abroad options for AFRC members as well as gratuity and resettlement offers. Those who refused were encouraged to retire with considerable benefits (Shillington, 1992). Chazzan (1989) and Shillington (1992) reported that Limann's government did not effectively retrace the downward spiral of the economy. Opposition groups rallied against the government, one such group, the June Fourth Movement (JFM), was formed by a group of students and intellectuals, who took their inspiration from the 1979 coup. JFM invited Rawlings to become a leader of the movement. On December $31^{\text {st }} 1981$, Rawlings returned to dethrone Limann and remained in power from 1981-2000, first as a military leader and from 1992, as a "democratically" elected president.

\section{The Fourth Republic}

The 1992 elections, won by Rawlings and the National Democratic Party, highlighted the role of ethnicity in Ghanaian electoral politics as did all elections (1996, 2000, and 2004) after that. Jerry John Rawlings being Ewe always guaranteed the Ewe vote. The 1992 elections ushered in the Fourth Republic and with it, a new Constitution. Chapter fourteen of the Constitution (1992) called for the creation of "The Public Services of Ghana" which should consist of-: the Civil Service, the Judicial Service, the Audit Service, the Education Service, the Prisons Service, the Parliamentary Service, the Health Service, the Statistical Service, the National Fire Service, the Customs, Excise and Preventive Service, the Internal Revenue Service, the Police Service, the Immigration Service; and the Legal Service.

The Constitution (1992) mandated the civil service "to assist the government in the formulation and implementation of government policies for the development of the country". It also stipulates that "Every department of government created by or under the authority of the law in a ministry shall be a unit under the ministry. The department/service shall be responsible for 
the implementation of the function for which it was created." The civil service, which consists of several ministries, formulates policy and the departments handle implementation.

\section{The Civil Service Workforce}

Ministries are staffed with political appointees at the apex, as well as professional administrators and their assistants. The civil service is divided into general classes and administrative classes. The secretarial/clerical class, the Typing Grades, the Machine operating class, the Messengerial Class and the General Service Class of Cleaners all make up the "general" classes (i.e., civil servants who come into the service without specialized training) for the tasks they perform and fill similar positions in all ministries and departments. The Administrative class (also part of the general class) is usually concerned with policy, managing the various ministries, advising ministers and coordinating the activities of government. The executive class handles administrative duties.

\section{The Department Workforce}

Departments, charged with implementing policies of their ministries or government, are staffed mostly by specialists, professional and/ or technical officers. The specialist classes fall into three groups: professional classes (e.g., doctors, lawyers, architects, engineers, educators) scientific and technical Staffs (statisticians, accountants, and scientists) and ancillary technical and supervisory staffs (e.g., laboratory assistants, and photographers). Specialist classes are limited to particular departments with little possibility of being transferred to other departments as such employees are trained in specific skills. 
Figure 2-1. Organizational Chart of GES and Ghana Civil Service

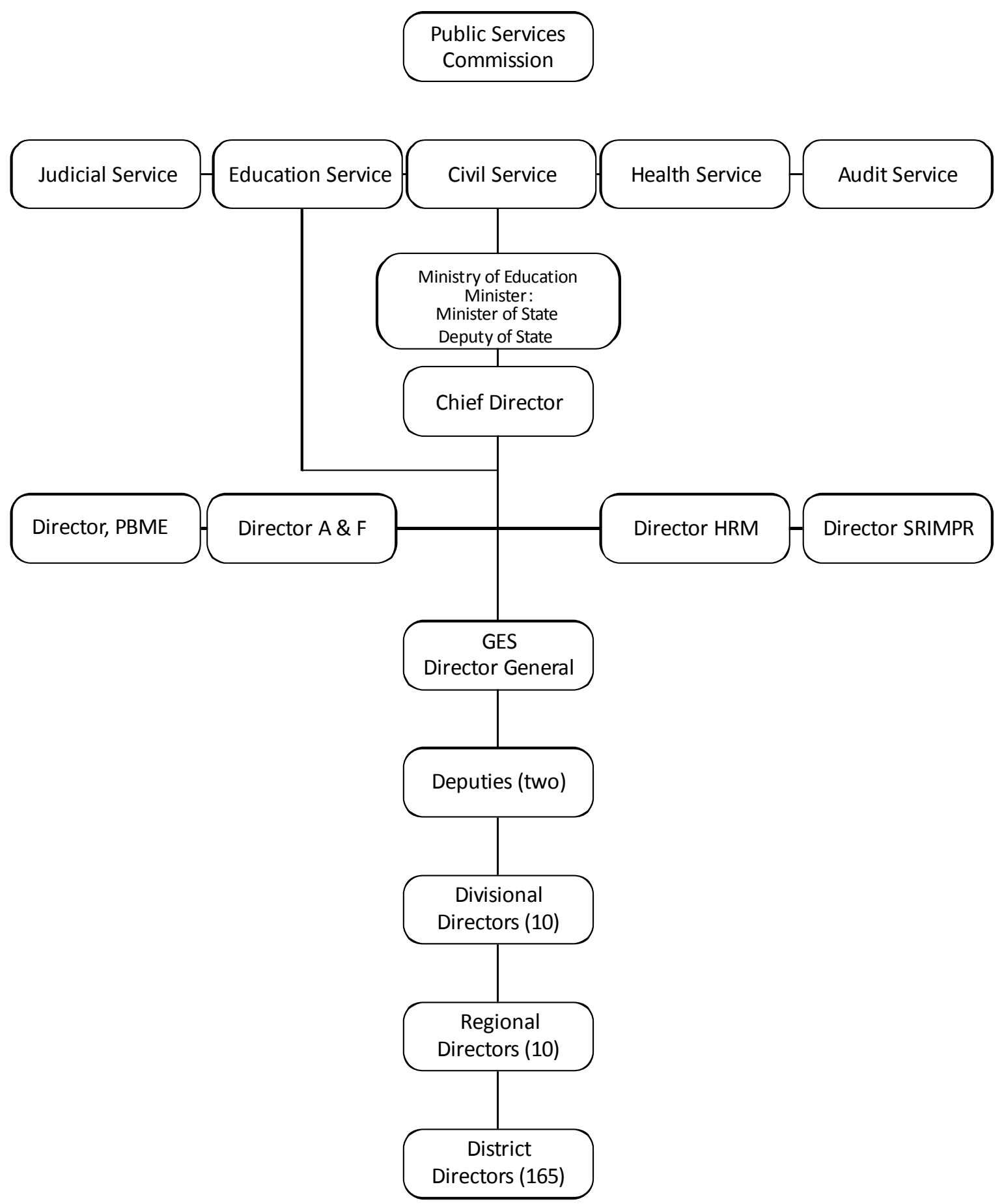




\section{The Ministry of Education and the Ghanaian Education Service}

The Ministry of Education and Sports (MOES) is the definitive administrator of education delivery in Ghana. The Ministry is in charge of formulating national policies on education. The Ghana Education Service (GES) is the implementing arm of the ministry and it comprises the headquarters with its constituent regional and district offices. At the highest level of the Ministry of Education is the Minister followed by a Minister of State, two Deputy Ministers and a Chief Director. The Chief Director coordinated work between the ministry and the GES. Under the Chief Director there are four Directors for Planning, Budgeting, Monitoring and Evaluation (PBME); Administration and Finance (A \& F); Human Resources (HRM); and Statistics, Research, Information Management and Public Relations (SRIMPR), respectively. Responsibility for education management emanates from the Ministry down to the regional and district levels. The schools are managed by the principals in collaboration with the School Management Committee (SMC) at the elementary level and board of governors at the high school level.

The Ghana Education Service is headed by the Director General assisted by two deputies and 10 Divisional Directors based in the national headquarters. At the regional level, there are ten regional directors for the ten regions of Ghana, each aided by four Assistant Directors who coordinate educational activities in the various districts. One hundred and sixty-five District Directors each supported by four Assistant Directors, oversee the implementation of educational policies at the district level. The Kuffour Government, elected in 2000, created new District Director positions thereby increasing the number from 110, to the current 165 . Figure $2-2$ captures the hierarchy of the GES and the civil service. 


\section{The 2000 Election}

The opposition party, the National Patriotic Party (NPP) won the 2000 election under the leadership of President Agyekum Kuffour. Ayee (2002) characterized the 2000 general elections as the most important political event in Ghana since 1957. This is because it signaled an exit from Ghanaian politics of Flight Lieutenant Jerry John Rawlings who had served as longest serving Head of State for over 19 years. The 2000 elections also marked the sturdiness of Ghana's fledgling democracy because of the smooth transition from the incumbent party that had been in power preceding the beginning of the Fourth Republic to an opposition party that had yet to enjoy the benefits and challenges of being in power.

Prior to the 2000 elections, fears were expressed by Ghanaians that conflict might arise in the aftermath of the elections. The opposition parties did not believe the NDC would willingly give up power should an opposition party win. Ghana had witnessed seemingly calm electoral processes degenerate into chaos in neighboring countries in Liberia, Sierra Leone and the Ivory Coast. Rawlings however did hand over power to the NPP.

The Kuffour regime came to power after 19 years of PNDC and NDC rule. The leadership was concerned that the bureaucrats in the state departments might be unwilling to follow the new direction the NPP wanted to take. Even though no dramatic changes in government personnel were made in public, in private some bureaucrats whose actions were suspected to be anti-NPP (because of their previous relationship with the NDC) were asked to proceed on leave. The administration also created new positions and commissions in some agencies to ensure policies were implemented in line with NPP goals. For instance the NPP created the ministerial positions of Public Sector Reform and Women and Children's Affairs. It also consolidated two ministerial positions into one position. The positions for Education 
Minister and the Minister for Youth and Sports were consolidated into the position of Education, Science and Sports.

Tiger (1963) posited that the Colonial Service was to blame for a politicized civil service. He maintained that the Colonial Service was the political and administrative government in the Gold Coast and for that reason it failed the requirement of neutrality that Weber advocated. It was therefore not a total replica of the British civil service. Tiger (1963) argued that this dual role that the Colonial Service played has caused the African civil servants to misunderstand the neutral role that the civil service had to play vis-à-vis the political leadership. The result was that when public servants attempted to be neutral, they were misconstrued by the politicians as taking positions against them.

\section{Ethnicity in the Kuffour Administration}

President Kufour, an Akan, won a majority of the Akan vote. Kuffour appointed a vice president from the northern region to buy the loyalties of voters in that part of the region. Asante and Gyimah Boadi (2004) argued that minor ethnic tensions in Ghana have not exploded into national conflicts because successive governments have adopted practices of symbolic distribution, representativeness and inclusion (p. 15). A cursory look at the names of the cabinet ministers and ministry heads in the Kuffour administration shows a majority being Akan. Akans constituted 69\% of the Kuffour administration in 2001 and 67\% in 2003 (Asante and GyimahBoadi, 2004).

\section{Conclusion}

The Ghana Public Service has been shaped by Ghana's administrative, social and political history. According to Tiger (1963) the public service is not immune to political considerations because its predecessor the Colonial Service embodied both administrative and political functions. Furthermore, Ghana's multiethnic society makes it difficult for the public 
service to be completely apolitical as ethnic groups expect to be rewarded for electing one of their own. Ghana's experience with military coups and different civilian regimes has undoubtedly shaped the bureaucratic institution. The bureaucracy enjoyed a prestigious position under military rulers as they latter needed the bureaucracy's support to govern effectively. Each government however attempted to bring the bureaucracy in line with its goals. Nkrumah, through the CPP often took over functions of the institution; Busia increased the composition of Akans in the bureaucracy; Acheampong granted bureaucrats greater autonomy in exchange for their loyalty; Rawlings under the AFRC empowered junior bureaucrats to the detriment of upper level public servants; Kuffour increased the number of Akans in the bureaucracy and asked tenured public servants, who appeared to be anti NPP, to proceed on leave. The result is a public service that is perceived to be neutral and apolitical on paper but that caters to the whims of the government of the day in order to survive. 
Chapter 3: Bureaucratic Motivation

\section{Introduction}

This chapter reviews three approaches to understanding the motivation of civil servants: principal-agent with its roots in microeconomics and self-interest; the enhanced principal agent model, which suggests peers as an influence and hypothesizes a wider variety of options on the subject of motivation; and Public Service Motivation (PSM) theory which posits that some employees are imbued with innate desires to serve the public. This chapter reviews these approaches in an effort to understand motivations of Ghanaian civil servants.

Motivation of the bureaucracy is an age-old question. Woodrow Wilson (1887), Frederick Taylor (1911) and Luther Gulick (1937) who adopted a top-down approach to management all believed that superiors provided the rudder for the subordinates' performance. This school of thought was not particularly kind to lower level workers and therefore constantly clashed with labor unions (Brehm and Gates 1997, p. 5-6). The school of thought that replaced the scientific management approach was the human relations school of management. This school adopted a more bottom-up approach to management. Contrary to scientific management theorists, these scholars insisted that optimum performance by subordinates was not always a function of superiors' actions. Barnard (1938), identified as one of the precursors of this movement, explored the reasons why individuals chose to obey conventions and argued that subordinates had to accept authority as being legitimate for them to defer to it (Barnard, 1938, $\mathrm{p}$. 86). Barnard, like later PSM theorists, doubted that monetary reward was a major motivator of workers. "It seems to me to be a matter of common experience that material rewards are ineffective beyond the subsistence level excepting to a very limited proportion of men; that most 
men neither work harder for more material things nor can be induced thereby to devote more than a fraction of their possible contribution to organized effort" (1938, p. 144).

\section{Principal Agent Theory}

Principal agent theory is an organizational theory with roots in economics. It attempts to explain relationships between contracting parties (Moe, 1984). An agency relationship involves at least two people, the principal and the agent, who are not necessarily of equal status. The principal delegates a task to be performed by the agent. Whenever an individual, group or organization contracts an activity to another entity, agency relationships are created. Principals and agents are assumed to possess different objectives so that once hired there is no guarantee that agents would do what principals want. Furthermore, agents possess exclusive knowledge of the extent of their skills and limitations, and the rational agent is expected to overvalue his/her worth in the bid for a job or a contract (Moe, 1984).

Mitnick (1984) introduced principal agent theory into political science in an effort to demonstrate that the root of the bureaucratic quandary could be traced to the problem of agency. He added that a dilemma of agency is that agents may not do what principals desire for two reasons: moral hazard and adverse selection. Moral hazard is when the principal cannot constantly monitor the agent's performance on the job because of the lack of resources (e.g. time and finances). Adverse selection occurs when an agent exaggerates his skills to the principal. As Moe (1984) stated, only agents are aware of their skills and are capable of overvaluing their worth. The principal on the other hand does not have the ability to judge whether the agent's skills are optimal for the principal's interests and may employ an agent that does not have the requisite skills hence the problem of adverse selection. Political scientists have employed principal agent theory to understand motivation of public sector employees (Brehm \& Gates, 1997; Golden, 2000; Huber \& Shipan, 2002). 
Brehm and Gates (1997) criticized traditional principal agent models as being too simplistic in their modeling of bureaucratic motivations. The authors disagreed that bureaucrats only preferred shirking their responsibilities and allow for a broader variation in bureaucratic behavior-working, shirking or sabotage. The authors do not take it for granted that bureaucrats automatically find pleasure in shirking since some bureaucrats actually love to work. Similarly, Golden (2001) identified the factors that affect bureaucrats choice to work or shirk (i.e., selfinterest, role perception, agency history, professional and agency culture) and demonstrated that bureaucrats exhibited four patterns of behavior-exit, voice, loyalty and neglect. Golden believed that of the four factors, "neglect" was a more common behavior among bureaucrats. In this case however neglect did not equate shirking but rather the situation where bureaucrats deferred to the principal for reasons other than loyalty. Neglect is the "default behavior when bureaucrats without strong ideological convictions are faced with an ambivalent policy" (2001, p. 19).

Brehm and Gates (1997) perceived a greater role for subordinates' preferences in the workplace. They echoed Barnard's (1938) views that effective supervision depended more on the characteristics of subordinates than that of supervision. For them moral hazard was less of a concern since supervision had minimal impact on the behavior of bureaucrats. The authors concluded that bureaucrats worked to fulfill their responsibilities even though principals may have very little influence on their behavior. The reason was that "fortunately for the public, the bureaucrats ...prefer work and serving the public" (Brehm \& Gates, p. 196). The authors added that the bureaucracy was filled with policy-oriented zealots, loyal advocates and statesmen, the types of individuals who are interested in working for the common good, yet each interprets the public good differently. 
Brehm and Gates (1997) found a plausible reason why agents would comply with principals even under conditions of information asymmetry. To accomplish this they modified the principal agent model by taking into consideration preferences of subordinates and by varying agents' disposition to work. The result was the Enhanced Principal Agent (EPA) model that did a better job of capturing the interaction between supervisors and subordinates and demonstrated the challenges associated with supervision and compliance in a bureaucratic setting. They tested the EPA model using computer simulations which they supplemented with analysis of data obtained from three surveys of federal employees administered by the Office of Personnel Management in 1979, 1983 and 1992 respectively. Questions on the survey ranged from employees' reported satisfaction with their pay, to their perception on the effectiveness of supervision. The authors measured performance of bureaucrats by examining self reports, reports of outside observers and administrative records to examine if bureaucrats worked hard or shirked their responsibilities as agency theorists posited. Brehm and Gates found that American bureaucrats were hardworking even with minimal supervision. A reason for this unanticipated behavior, Brehm and Gates posited, was that bureaucrats value both pecuniary and nonpecuniary rewards.

Pecuniary rewards referred to pay, promotions, job security, and leisure; all incentives that principals gave to agents to encourage them to perform optimally. The authors distinguished between two kinds of non-pecuniary rewards (i.e., "functional" and "solidary" benefits). A functional preference was observed when a subordinate derived satisfaction from doing the very things he or she was supposed to do. A solidary preference for one's job happened when a subordinate loved to work because of the camaraderie with colleagues and peers. Analysis of the data demonstrated that some bureaucrats preferred non-pecuniary to pecuniary rewards in which 
case the former worked with or without supervision. For instance Brehm and Gates found that bureaucrats with high functional preferences tended to work hard on the job. The authors noted further that supervision was more likely to discourage shirking or sabotage than actually induce work. They also stated that supervision would work when superiors focused on amenable subordinates rather than saboteurs or slackers. Their study echoes classics such as Mary Parker Follett (1926) and James Wilson (1989). Follett (1926) argued that not only the wishes of the supervisor mattered, subordinates' preferences mattered as well and as a result superiors could not afford to demand unquestioned conformity. Wilson suggests bureaucrats' actions are influenced by the need to manage a workload, expectations of peers, professional norms, their own convictions, and the needs of clients (1989).

Brehm and Gates (1997) recommended that principals expend their scarce resources in employing the right agent for the job rather than attempting to induce compliance by agents with low functional preferences. They concluded the problem with principal-agent relationships is actually one of adverse selection and not moral hazard. If principals were able to choose agents with the right skills, who shared their goals, the need for supervision would be minimal.

Golden (2000) examined how civil servants at four different agencies (the National Highway Traffic Safety Administration, Food and Nutrition Service, Civil Rights Division, and the Environmental Protection Agency) reacted to the Reagan administrative policy demands. She interviewed 70 high level civil servants, synthesizing responses into four distinctive themes: exit, voice, loyalty and neglect. By and large, senior level bureaucrats complied with Reagan's programs. However she noted that bureaucratic behavior varied "both within and across agencies" (p. 152). Factors such as organizational culture and professional orientation conditioned the responses of bureaucrats to their political principal. For instance she noted that 
lawyers who are professionally argumentative and verbose are more likely to question the directives of principals.

The above discussion centered on bottom up theories and rational choice theory that suggests that individuals are interested in maximizing benefits and minimizing costs, all theories that attempt to explain bureaucratic behavior. The next section reviews the literature on public service motivation, another theory that explains the same.

\section{Public Service Motivation}

Public Service Motivation (PSM) is a concept that examines the relationship between motivation and public interest. Moynihan and Pandey (2007) attempted to understand employees' perceptions of public interest, "why they develop a strong sense of public interest and how it influences their behavior" (Moynihan and Pandey, 2007, p. 3). PSM theorists are interested in confirming the existence of PSM by comparing motivations of employees across sectors (public, private, non-profit). PSM therefore enable us to understand why public servants choose this career path and is a valuable theoretical supplement to Brehm and Gates' Enhanced Principal Agent model.

Scholars of PSM employ the definition originated by Perry and Wise (1990) which holds that PSM is "an individual's predisposition to respond to motives grounded primarily or uniquely in public institutions and organizations" (Perry \& Wise, p. 368). One of the earliest scholars of PSM (Buchanan, 1975) found that public sector managers had lower levels of job involvement as compared to their private sector counterparts; concluding that public managers were frustrated with their jobs. Rainey (1982) found the opposite when he replicated Buchanan's study. By asking questions directly related to public sector work, he found that public managers scored higher points on job satisfaction than did managers in the private sector. Perry and Wise (1990) identified a typology of motives associated with but not exclusive to the public service that 
included rational, norm-based and affective motives. Normative motives inspire a desire to serve the public interest and are characterized by loyalty to duty and government as a whole. Rational motives arouse a commitment to public service programs because of an individual's personal identification with them and advocacy for special or private interests. "Affective motives are grounded in human emotions and are characterized by a willingness and desire to serve others" (Perry \& Wise, 1990, p. 368). The authors hypothesized that individuals with high PSM are likely to seek employment in public service and are likely to perform better than individuals with low PSM. They also posited that public organizations that attracted high PSM level employees were likely to be less dependent on utilitarian incentives to motivate clients.

In line with Perry and Wise's research, several scholars (Brewer, Selden \& Facer II, 2000; Crewson, 1997; Houston, 2000; Naff \& Crum, 1998) have examined the existence of PSM and have found supporting evidence that the presence of PSM positively impacts productivity in public sector employees. For instance, Naff and Crum (1998) found that federal employees with high levels of PSM had higher levels of job satisfaction, had more positive performance appraisals and were less likely to want to leave government service than those with lower PSM.

Brewer, Selden and Facer (2000) noted that individuals have different motivations for joining the public service. Following Perry's (1996) elucidation of the PSM construct with the development of forty statements representing six dimensions of PSM: attraction to public policymaking, public interest, compassion, self-sacrifice, civic duty and social justice, the authors administered the statements on 69 respondents via Q-methodology. From the analysis, they identified four kinds of individuals: Samaritans, patriots, humanitarians and communitarians. Samaritans are touched by the plight of the less advantaged and find personal gratification in helping others. Communitarians believe citizens should give more to society than 
they receive. Patriots on their part are willing to risk everything for the rights of others and for the good of society, while humanitarians want to make a difference in society, an act that means more to them than personal achievement.

Houston (2000) sought to discover if public employees were more likely to value intrinsic rewards over extrinsic ones. The author utilized data from the General Social Survey and conducted multivariate analyses (previous studies have used bivariate analysis) to control for background characteristics to determine if significant differences existed between the public and private sectors in terms of the impact of varied employee reward schemes. He found that public employees were more likely to place higher value on intrinsic rewards when work in question was considered important and provided a feeling of accomplishment. Private sector workers on the other hand were more likely to value extrinsic rewards (e.g., high income and short work hours). Houston's findings were in sync with other authors such as Bright (2005), Kilpatrick, Cummings and Jennings (1964), Rainey (1982), Schuster (1974) and Wittmer (1991). Houston demonstrated that public employees were more likely to value job security a finding that he admits, is contrary to the PSM concept that if individuals are motivated by intrinsic rewards they are likely to place less emphasis on job security. Houston's finding is however consistent with the general perception of government workers (Baldwin, 1987; Bellante \& Link, 1981; Jurkiewicz, Massey \& Brown, 1998; Price, 1975; Schuster, 1974). On the other hand several studies (Gabris and Simo, 1995; Rainey, 1982; Wittmer, 1991) did not find differences in attitudes toward job security among public and private sector employees. Houston (2005) undertook further research on PSM to determine if public sector employees were more generous than private sector employees. Using multivariate analysis on the 2002 General Social Survey, 
he found that public sector employees were more likely to volunteer time, donate blood and donate money to charitable activities.

Further support for the existence of public service ethic in government jobs is offered by Crewson (1997) in his examination of three secondary data sources - the General Social Survey, the 1979 Federal Employee Attitude Survey and the 1994 member survey of electrical engineers. Crewson's study is important because he compares employees of the same profession (engineering) in different sectors. When public and private sector engineers were compared, the Crewson found that the former were more likely to give high ratings to "doing something useful for society" and "helping others". He agrees with the pro-PSM camp that public employees value helping others and being useful to society than private sector (Blair \& Garand, 1995; Brewer, 2003; Conway, 2000; Rainey, 1997). He also remarked that service motivated federal employees will be more productive than economic oriented ones. This suggests that a delicate balance be achieved between providing adequate economic rewards and taking care not to destroy or ignore intrinsic or service needs of pub employees.

In the quest to measure the work ethic of individuals with PSM, some scholars have examined the relationship between perceptions of red tape and level of PSM (Scott \& Pandey, 2005). Scott and Pandey argued that individuals with high PSM would be less likely to see rules and procedures in negative terms but would be more accommodating in their perceptions of these rules. They created a survey instrument geared toward managers adopting the four dimensions of PSM created by Perry $(1996,1997)$ : attraction to public policy making, civic duty, compassion and self sacrifice. The authors dropped the self-sacrifice dimension from the survey because they felt it was similar to the compassion dimension. Scott and Pandey (2007) found evidence that public employees with high PSM levels were less likely to perceive rules as red tape but rather as 
legitimate requirements. They also found that of the three dimensions, attraction to public policy making seemed to have the most impact on perceptions of red tape.

Perry $(1996,1997)$ studied the relationship between PSM and a number of demographic factors and found PSM to be positively related to education level and age and negatively related to income level (1997). Blank (1985) also researching the relationship between demographic factors and public sector employment posited that non-whites and women appeared to incline toward public sector employment. Bright (2005) investigated the relationship between PSM and three factors: personal characteristics, management level and monetary preferences of public employees. Bright's findings gave credence to both Blank and Perry's results—respondents with high levels of PSM were significantly more likely to have higher levels of education and were more likely to be female than those with lower levels of PSM. Bright admitted though that a limitation to his study was that he under sampled males in the study, a fact that could have skewed his results. He also conjectured that individuals are influenced by the role society assigns them based on gender. Males are generally expected to be competitive, aggressive and dominant while females are to assume caretaking roles. This could explain why males are less attracted to public service than are females. Other findings were that non-managers had significantly lower levels of PSM, than those working in managerial positions, and high PSM individuals valued monetary rewards less than low PSM employees.

Not all PSM scholars tend to agree with Perry and Wise (1990) or their supporters Alonso \& Lewis, 2001; Gabris \& Simo, 1995; Mann, 2006). Gabris and Simo (1995) compared responses of employees from municipal government, the private sector, and non- profit organizations in effort to discuss motivational differences. They employed an open-ended survey in an effort to determine why employees took their current positions, whether they planned to 
stay, and why. The authors found that motivational needs were randomly distributed between the nonprofit, public and private sectors. Employees from the three sectors reported a high level of job satisfaction and none of them viewed public sector employment as the ideal job. The authors noted that the public sector seemed to have a low opinion of itself and was frustrated by its own organizational setting. They argued that as individuals progressed in their careers, regardless of sector, the kinds of needs that exert powerful motivational force converged. In addition, Gabris and Simo (1995) maintained that only individuals in the top hierarchies of a public organization remained instilled with public motivational need. At lower levels employees are concerned with monetary incentives, job security, and fringe benefits. "The average public sector employee, even those professionally trained work in the public sector because it represents a presumably secure job that satisfies basic extrinsic needs rather than because it ameliorates a vague intrinsic need for serving the public" (Gabris \& Simo, 1995, p. 40). The authors concluded that PSM may exist, but it was virtually impossible to segregate and identify it. Their advice to future researchers was to abandon PSM as the motivation to serve the general community since it was not monopolized by any particular sector.

Mann (2006), like Gabris and Simo (1995), included non-profit employees and private employees in his study. He expected employees of each sector, particularly federal employees, to praise their organization as the best for helping people and for delivering services on their behalf. Mann was surprised that most federal and private sector employees agreed that the best sector for helping people was the non-profit sector. In his study Mann had hoped to examine how the public service ethic (inherent in PSM) could be harnessed to guide human resource managers in their hiring decisions. Mann posited that in as much as individuals may have inherent motives for 
serving in the public sector "it remains unclear how human resource managers can take advantage of this motivation in recruiting and selecting better employees" (p. 43).

Alonso and Lewis (2001), critiques of anti-PSM camp, tested the link between PSM and job performance in the federal service. The authors analyzed the 1991 Survey of Federal Employees and 1996 Merit Principles Survey. They used federal grades and job ratings as a measure of long-run job performance. The authors asked respondents about the impact of merit considerations on reward schemes in the organization. They hypothesized that high PSM individuals will expect the link between merit and rewards to be weaker and opined that employees, who saw a stronger link between merit and rewards will perform better, achieve higher grades and receive higher performance ratings. The authors found no evidence that those who highly valued service to others achieved higher performance ratings. Contrary to previous findings, not only did PSM have no perceptible impact on grade level but placing a high value on service to others was negatively related to grade level. Alonso and Lewis strongly dispute the assertion that incentive programs are less effective or counterproductive in employees with high PSM. Employees, when they believed that their organization granted promotions based on ability, skills and performance appeared to work harder regardless of whether they had low or high PSM. They concluded that not only was public service motivation weakly associated with the performance of federal employees but that it could decrease the performance of those who cared about rewards.

\section{Motivation of Ghanaian Bureaucrats}

Price's (1975) study of motivation of civil servants in Ghana found one of the motivators

of Ghanaian bureaucrats not captured in any of the preceding discussion to be expectations of family members (nuclear or extended). Price (1975) explained that African societies are not oriented to rules in the manner of Western societies. Civil servants in Ghana and other 
developing nations act in particularistic fashions because such societies are communal, unlike advanced industrialized countries that tend to be more individualistic. Family members in these societies have certain expectations of civil servants, which the latter tend to fulfill. As a result, Price (1975) maintained that national institutions such as the legislature and administrative agencies have not functioned effectively in developing countries because these institutions are exogenous to these societies. They were introduced into these societies as a result of their colonial inheritance to "fulfill similar functional needs". Price (1975) noted however that these institutions developed in their host countries as results of extensive periods of social and cultural change, a fact that is corroborated by Galambos (1987), Skowronek (1982) and Morone (1998). Traditionally, economists expect nuclear family systems to have fewer expectations of family members who are entrepreneurs as compared to extended family units. Price (1975) objected to this assertion and posited that "the corporate nature of kinship units rather than the extent of membership is the factor that places strain on bureaucratic relationships within African societies" (Price, 1975, p. 26). In other words, nuclear family units are not disengaged from the extended families and are equally susceptible to demands from other relatives just as much as extended family units are. Price (1975) aptly captured the nature of familial relations in communitarian societies in the passage below:

[i]ndividuals in these societies are viewed as extensions of their corporate groups to the extent that they have no autonomous existence and identity outside their group membership... Relations of a bureaucratic official therefore tend to appropriate any bureaucratic positions held by their relative. ...not only will the bureaucrat be expected to behave in the correct particularistic fashion when he encounters a member of his extended kinship group in the bureaucratic setting but in general will be expected to use his office in a manner that will enhance the wealth, status and influence of his group...To refuse demands of this type by giving precedence to one's identity as a bureaucrat and one's commitment to the universalistic norms of the bureaucratic role 
would be tantamount to defining oneself as outside the corporate group" (p. 26).

Price (1975) argued further that the hold on public employees by family members is so strong that it would be rare for supervisors to discipline subordinates when the latter's behavior does not conform to organizational norms as the superiors are subject to similar role expectations and are likely to see the particularistic behavior of subordinates as normal. Price's study demonstrates that motivations of bureaucrats in non -Western settings are equally varied yet distinct from motivations of bureaucrats in the Western world.

The preceding section examined the literature on various theories about bureaucratic behavior. This study attempts to determine if rational choice theory or public service motivation can best explain bureaucratic behavior of Ghanaian public servants. In the next section I examine the methodology to be employed for this study.

\section{Methodology}

The surveys for this study were adaptations from the Price and Brehm and Gates studies. I adopted Price's method of administering three related attitude surveys which he referred to as the Civil Servant Survey, the Clientele Survey and the Comparison/Clientele Survey. The Civil Servant Survey was designed to ascertain the identity of their "significant others", "their opinions of the role expectations held by these significant others, and the sanctions they believed were likely to be forthcoming against them if these expectations were violated" (Price 1975, p. 46). I adopted most of Price's survey questions and modified them where necessary in order to make them more applicable to current respondents. I supplemented these questions with those from the Federal Employee Attitudes Survey and the Survey of Federal Government Employees that focused on the impact of solidary, functional and pecuniary motives as well as the impact of supervision on the behavior of the bureaucrat. Price's design of the Clientele Survey, which I 
adopted, was to determine how they felt a civil servant should behave as compared to how they actually do behave. It also examines their perceptions of the ramifications for the civil servant for the afore-mentioned behaviors. The Comparison/Clientele Survey was very similar to that of the Clientele Survey but was geared toward non-literate respondents.

I converted some open-ended questions in Price's survey into close-ended questions to make comparisons of responses facile at the analysis stage. I conducted a pilot study with ten respondents from the three groups to ensure that the questions were clear and the questionnaire was relatively easy to complete. I made minor changes in choice of diction, after examining feedback from respondents, particularly with the questions employed by Brehm and Gates as these were particularly designed for a Western audience. Price presented different scenarios and respondents (see Appendix) were asked about the likely behavior of the civil servant in the imaginary situation and about the actions of other actors. I maintained this approach because it allows respondents to extrapolate from their personal experience and yet not be threatened that they would be judged by their responses.

\section{Research Questions}

Chapter Two examined the impact of the Colonial Service and Ghana's political history and the development of the bureaucracy. It was established that the bureaucratic institution is neither apolitical nor completely neutral due to exigencies of a multi-ethnic culture as well the demands of military and civilian political officials. This study attempts to answer the following questions:

1) Does the variation in political regimes have an impact on the work performance of bureaucrats?

2) Do differences exist in the perceptions and expectations of 1969 and 2006 respondents? 
3) Are demands from ethnic and familial groups moderated for 2006 respondents who have had greater access to Western culture?

4) Does the extended family play a greater role in the work performance of Ghanaian bureaucrats than they do for American bureaucrats?

5) Are Ghanaian bureaucrats motivated by functional, solidary and pecuniary preferences?

6) To what extent does supervision shape employee work performance?

Sample: Public Servants

An ideal sampling method would have been to draw a random sample from the national pool of Ghanaian public servants. However financial and time constraints hindered the use of random sampling. To identify respondents for this study, I focused mainly on the Greater Accra and Eastern regions of Ghana. Ghana is divided into ten regions with each comprising different ethnic groups and each having its own administrative headquarters. The Greater Accra Region is the smallest and yet the most densely populated. It houses Accra, the capital of Ghana and home to the national administrative quarters. Accra is also the nation's major commercial, industrial and transportation center. Accra is traditionally home to the Ga ethnic group however with a current population size close to three million, it is a good mosaic of the various Ghanaian ethnic groups and an ideal location for sampling purposes. Sampling from the Eastern region allowed for the examination of different viewpoints of bureaucrats from a different socio-economic ecology — this made it possible to compare the perceptions of the Eastern region respondents to their public service counterparts at the national headquarters in Accra. In the Eastern region, respondents were chosen from Nsawam, a town approximately $40 \mathrm{~km}$ from Accra which accommodates one of the district offices (the Akuapim South district) of the Ghana Education 
Service. Nsawam was chosen because of its proximity and more importantly for the ecological, economic and political diversity it introduced in the respondent sample.

I administered 200 questionnaires to Ghanaian public servants. Respondents were identified from the national headquarters and regional levels of government. Two of the largest services in the public service - the Ghana Education Service (GES) and the Civil Service provided the respondents for this study. Respondents were of different occupational levels to ensure supervisory personnel did not feel beleaguered or perceive the survey as a threat. The questionnaires for the civil servants were administered to respondents at the national headquarters for the civil service and at the civil service training school. Most of the questionnaires were distributed to respondents via accidental sampling at their work place. Accidental samples are those that are obtained because cases are easily obtainable (Selltiz, Wrightsman, \& Cook, 1976). At the Nsawam District Education office, I encountered a sizeable number of bureaucrats from all over the Akuapim South district who had business to take care of at the education office. For the civil servants I handed out some questionnaires at the Civil Service Training School, a location where I could get a random sample of civil servants since learners in that institution come from all sectors and levels of the civil service. In a few cases, respondents returned the surveys to me immediately. In most cases, respondents were asked to drop off surveys at a central location at their workplace where I went frequently to pick them up. Of the 200 questionnaires, 130 were returned however 13 of them were eliminated because most of the questions had not been answered. One hundred and seventeen questionnaires remained for data analysis for a return rate of $58.5 \%$.

\section{Sample: Clientele}

The choice of word "clientele" as employed by Price is to refer to all members of the public, since they are all likely users of the public bureaucracy. The Clientele Survey as 
designed by Price (1975) had two main objectives which I adopted: 1) "To provide data on the Ghanaian public's orientation to the client role in bureaucratic relationships. 2) To permit an assessment of the social support available to Ghanaian civil servants for various types of role behavior they are called upon to make in the course of their official duties" (Price, 1975, p. 51).

Price selected part of the client group from the University of Ghana (UOG) in Accra, a state-owned institution with students from every region of the country. Price (1975) noted that university students had more contact with the civil service than most other Ghanaians. Every college student in a public university in Ghana is entitled to receive a loan from the national government. Very few students elect not to take the loan. Students have to go through varied processes with the bureaucracy for their applications to be processed. This makes them an attractive sampling universe. The university student sample may be a biased group especially since the process of getting loan applications approved can be tedious thereby making them excessively hostile. Price (1975) argues that since the public service recruits from the university, it will be useful to know what future public servants think of the institution. The university sample also has a diverse socio-economic background (e.g., ethnicity, hometown, occupational background, and parental wealth). This study examines if changes in perceptions have taken place since Price conducted his study in 1968 and 1969. Evaluating attitudes of college students allows me to compare responses to Price who employed this group as well. That notwithstanding, I included other literate respondents. Literate for this study is defined as individuals with at least high school education. Questionnaires were administered to students in class settings with the permission of their professors. One hundred and thirty questionnaires were administered to students at the main UOG campus and 40 were administered at the workers college campus. Students at the workers college campus are mostly full time workers therefore 
their responses would help mitigate any biases that regular college students might have. Fifty questionnaires were administered to literate respondents who were not currently in college. To identify these respondents, I employed the snowball method where I identified a few respondents who in turn introduced other respondents to me. In sum, 220 questionnaires were administered to the clientele group and 190 were returned for a response rate of $86.36 \%$.

\section{Sample: Comparison/Clientele Survey}

To delineate the impact of education on their expectations of their "significant others", and also to obtain perceptions of those less highly educated, a modified version of the clientele questionnaire was administered to 60 respondents. Respondents were solicited from churches and other public places. Churches are useful because pastors may or may not use English as a medium of teaching depending on the educational background of their congregation. Churches with a high non-literate and semi-literate congregation conduct services in local languages not English. English is a medium of instruction in Ghana therefore non-English speakers would not have had formal education. Fifty-three respondents were interviewed. Three of the questionnaires were discarded because respondents had had no previous dealings with bureaucrats. The Comparison/Clientele Survey enables the comparison of the responses of college students with a sample that is more representative of the Ghanaian population.

\section{Conclusion}

The design adopted for this study has some notable strengths. The sampling universe employed in this study was varied and relatively large for the time period under investigation. The issues being explored have a firm theoretical grounding and the questions adopted in the surveys have been previously utilized by students of motivation. That notwithstanding, there are limitations associated with employing survey instruments. How does one determine if the interpretation given to survey responses is actually valid? To mitigate this problem, I converted a 
majority of the questions adopted by Price and Brehm and Gates into close-ended questions where respondents could make a choice from different alternatives. This in itself has a tendency to force respondents to respond in a certain way when they might have other preferences. However, the goal was to have respondents to choose the best response among specific alternatives as a result limiting their responses with close-ended questions was not an inappropriate method. Another limitation relates to the traveling problem (Sartori, 1970). The concept examines the extent to which measures constructed for use in one political setting can be useful in another setting. Some of the words employed by Brehm and Gates in their survey on American bureaucrats had to be substituted as they evoked different images in the minds of Ghanaians. These changes were minimal however. I pre-tested the questionnaire on a sample of public servants in Ghana before administering the survey.

Another limitation is the translation of the questionnaires for the non-literate clientele respondents. It is inevitable that some meaning is lost when translations from one language to another takes place. To have variation in my respondents, I had to employ the help of someone who spoke other dialects. It is possible that we interpreted some questions differently which might have affected the responses. On some occasions, I interviewed respondents in a group of three or four concurrently. I was careful to explain to respondents that they should not be influenced by the responses of their peers and that I was interested in their frank perceptions, however, bias may have been introduced. To reduce this problem, group interviews were relegated to a minimum for situations where respondents were in group on my arrival (e.g., mechanics resting under a mango tree on a sunny afternoon; tomato vendors on their way to pick up their wards from school). Finally my sample is not randomly selected. That notwithstanding, I went to great lengths to administer questionnaires in varied locations. 
This chapter reviewed the literature on motivation. It has also discussed the methodology for this project. In Chapter 4, I analyze responses from public servants in an effort to determine if their perceptions of the role expectations from their significant others have changed since Price conducted his study. I also examine if functional, solidary and pecuniary motives can be identified in Ghanaian bureaucrats and to what extent that these motives influence their work performance. Finally these analyses would help me make a preliminary hypothesis about the existence of PSM among Ghanaian bureaucrats. 
Chapter 4: Results of the Public Servant Survey

This study has three goals: a) To determine whether the variations in motivations that Brehm and Gates identified among American federal bureaucrats are visible among Ghanaian bureaucrats. b) To examine if public service motivation has taken root among public servants in Ghana. c) To observe the extent to which expectations of present bureaucratic clientele mirror responses in Price's study. In this chapter I analyze responses from the Public Servants Survey which was a replication of questions from Brehm and Gates and Price's studies. The goal in this chapter is to observe variations in motivations of public servants and the extent to which these motivations follow trends in Brehm and Gates' conclusions. This chapter also examines the public servant's perception of expectations from their significant others, while making comparisons with Price's findings to determine if changes have occurred over the past four decades.

\section{Characteristics of Public Servant Respondents}

This section examines characteristics of the public servant respondents such as place of work, level of education, gender distribution, and tenure in the public service. Public servant respondents for this survey were solicited from the Greater Accra Region and the Eastern Region of Ghana. Respondents worked at the Ghana Education Service (GES) and the Civil Service (which comprises several ministries). Table 4-1 portrays the characteristics of the respondents from the public service.

\section{Variations in Motivations of Bureaucrats}

Respondents were asked questions related to the role of supervision in order to determine the extent to which superiors shaped the bureaucrat's work performance. It was therefore 
Table 4-1. Characteristics of Public Servant Respondents (Percent)

\begin{tabular}{|c|c|}
\hline Description & Percent \\
\hline \multicolumn{2}{|l|}{ Age } \\
\hline $45-50$ & 94.4 \\
\hline $60-65$ & 5.1 \\
\hline \multicolumn{2}{|l|}{ Gender } \\
\hline Male & 65.0 \\
\hline Female & 35.0 \\
\hline \multicolumn{2}{|l|}{ Level of education } \\
\hline Bachelor's degree & 29.7 \\
\hline Associate's degree & 48.9 \\
\hline High school education & 21.4 \\
\hline \multicolumn{2}{|l|}{ Place of work } \\
\hline Ghana Education Service & 52.1 \\
\hline Civil Service & 47.9 \\
\hline \multicolumn{2}{|l|}{ Number of years in the service } \\
\hline $1-10$ & 40.3 \\
\hline $11-20$ & 20.7 \\
\hline $21-30$ & 19.9 \\
\hline $31-40$ & 19.1 \\
\hline
\end{tabular}

necessary to know whether respondents were managers of subordinates and if they reported to superiors. Table 4-2 captures responses to these questions. 
Table 4-2. Percentage of Public Servants with Supervisory Responsibilities

Description Percent

\begin{tabular}{ll}
\hline Percentage reporting to superiors & 83.8 \\
Percentage not reporting to superiors & 12.8 \\
Respondents that oversee subordinates & 51.3 \\
Respondents with no subordinates & 41.0 \\
\hline
\end{tabular}

In order to determine the extent to which supervision shapes employee behavior, it was necessary to evaluate the actions superiors took in response to slacking employees. Brehm and Gates (1997) found only $40.6 \%$ of 1983 respondents agreed that American supervisors took

Table 4-3. Supervisor's Response to Slacking Employee-Comparing American and Ghanaian Bureaucrats (Percent).

\begin{tabular}{|c|c|c|c|c|c|c|c|c|c|c|}
\hline & \multicolumn{2}{|c|}{$\begin{array}{l}\text { Strongly } \\
\text { Agree } \\
5\end{array}$} & \multicolumn{2}{|c|}{ Agree } & \multicolumn{2}{|c|}{ Neutral } & \multicolumn{2}{|c|}{ Disagree } & \multicolumn{2}{|c|}{$\begin{array}{c}\text { Strongly } \\
\text { Disagree } \\
1\end{array}$} \\
\hline & Ghana & US & Ghana & US & Ghana & US & Ghana & US & Ghana & US \\
\hline $\begin{array}{l}\text { 4-3.1 When an employee } \\
\text { continues to do his/her } \\
\text { job poorly, } \\
\text { supervisors will take } \\
\text { corrective action }\end{array}$ & 54.7 & 6.2 & 36.8 & 34.3 & 3.4 & 14.6 & 29.3 & .9 & 2.6 & 15.6 \\
\hline $\begin{array}{l}\text { 4-3.2 My job performance is } \\
\text { carefully evaluated by } \\
\text { my supervisor }\end{array}$ & 37.6 & - & 52.1 & - & 2.6 & - & 5.1 & - & 1.7 & - \\
\hline $\begin{array}{l}\text { 4-3.3 My supervisor insists } \\
\text { that subordinates work } \\
\text { hard }\end{array}$ & 44.4 & - & 41.9 & - & 6.8 & - & 3.4 & - & 0 & - \\
\hline $\begin{array}{l}\text { 4-3.4 My supervisor sets } \\
\text { clear goals for me in } \\
\text { my present job }\end{array}$ & 26.5 & - & 53.0 & - & 6.8 & - & 8.5 & - & 1.7 & - \\
\hline $\begin{array}{l}\text { 4-3.5 I will be demoted or } \\
\text { removed from my } \\
\text { position if I perform } \\
\text { poorly }\end{array}$ & 20.5 & - & 42.7 & - & 15.4 & - & 10.3 & - & 6.0 & \\
\hline
\end{tabular}


corrective action when an employee slacked ${ }^{1}$. The authors concluded that American subordinates perceived supervisory activity as being weakly related to subordinate rewards. Contrast this with Ghana where a majority of Ghanaian employees $(91.5 \%)$ concurred that when an employee continually slacked, supervisors would take corrective action (4-3.1). Other questions relating to the impact of supervision on employee performance were asked of Ghanaian respondents (4-3.2 to 4-3.5).

Responses in 4-3.2 to 4-3.5 demonstrate that supervision plays an important role in shaping performance of public servants in Ghana. It appears that supervisors monitor subordinates to ensure compliance and subordinates respond to direction. The ratio of respondents acknowledging the positive effect of supervision to those giving little or no weight to its effectiveness averages $3: 1$. This does not come as a surprise as Ghanaian society values deference to authority.

Respondents were asked to evaluate their work performance to determine whether they were slackers or hard workers. Responses to this question would allow preliminary conjectures to be made about the role of functional motives. While it may not be the best method to measure work performance as most people are likely to self-report that they work hard, "it is better to examine biased self-assessments of activity than it is to assume minimal activity without the benefit of any data" (Brehm and Gates, 1997 p. 90). The first statement in Table 4-4 was presented to both American and Ghanaian bureaucrats. The questions from 4-4.2 to 4-4.5 were only asked of Ghanaian bureaucrats. Brehm and Gates supplemented respondents' evaluations with those of their superiors thereby making their assertion about the hardworking nature of

\footnotetext{
${ }^{1}$ In isolated cases, Brehm and Gates employed descriptive statistics to analyze responses. In such cases responses from Ghanaian bureaucrats will be compared to those of their American counterparts to determine if similarities exist between the groups.
} 
American bureaucrats credible. Without access to supervisors' appraisals, a variety of questions, not asked of American bureaucrats, were presented to Ghanaian respondents to evaluate the veracity of the latter's responses.

Table 4- 4. Perceptions of Public Servants about their Work Performance (Percent)

\begin{tabular}{|c|c|c|c|c|c|c|c|c|c|c|}
\hline & \multicolumn{2}{|c|}{$\begin{array}{l}\text { Strongly } \\
\text { Agree } \\
5\end{array}$} & \multicolumn{2}{|c|}{ Agree } & \multicolumn{2}{|c|}{ Neutral } & \multicolumn{2}{|c|}{ Disagree } & \multicolumn{2}{|c|}{$\begin{array}{c}\text { Strongly } \\
\text { Disagree } \\
1\end{array}$} \\
\hline & Ghana & US & Ghana & US & Ghana & US & Ghana & US & Ghana & US \\
\hline $\begin{array}{l}\text { 4-4.1. Most of the people } \\
\text { here work hard on } \\
\text { their job }\end{array}$ & 30.8 & 27.0 & 49.6 & 53.6 & 6.8 & 13.4 & 9.4 & 4.4 & 1.7 & 1.5 \\
\hline $\begin{array}{l}\text { 4-4.2. I am not paid } \\
\text { enough so I only } \\
\text { give enough effort } \\
\text { to get by and keep } \\
\text { my job }\end{array}$ & 16.2 & 2.5 & 22.2 & 23.5 & 9.4 & 16.4 & 31.6 & 37.1 & 17.9 & 20.5 \\
\hline $\begin{array}{l}\text { 4-4.3. I am one of the } \\
\text { hardest workers in } \\
\text { my office }\end{array}$ & 39.3 & - & 42.7 & - & 10.3 & - & 5.1 & - & .9 & - \\
\hline $\begin{array}{l}\text { 4-4.4. I will work harder } \\
\text { than I currently do, } \\
\text { if I worked in a } \\
\text { private organization }\end{array}$ & 12.0 & - & 18.8 & - & 19.7 & - & 26.5 & - & 20.5 & - \\
\hline $\begin{array}{l}\text { 4-4.5. I get good reviews } \\
\text { from my supervisors }\end{array}$ & 17.9 & - & 52.1 & - & 19.7 & - & 2.6 & - & 4.3 & - \\
\hline
\end{tabular}

Statement 4-4.1 is a general one about all employees and not the respondent in particular; therefore respondents are expected to be more honest in their response. A majority of American and Ghanaian respondents agreed that employees in their organization worked hard.

Examinations of questions 4-4.2 to 4-4.5 confirm statement 4-4.1. It appears that Ghanaian employees believe they work hard. The consistency in responses for the varied statements validates favorable reviews of co-workers. It is interesting that respondents do not expect employment in the private industry to change their attitude to work. This challenges the 
perception that private employees are more hard working than public employees. Both Ghanaian and American bureaucrats did not expect low salary levels to diminish their output however Ghanaians are more likely to agree strongly that it would, a finding that is not too surprising as it is not uncommon for government employees to demand a tip before performing a service (See discussion on "dashing"). The claim that Ghanaian public servants work hard is not corroborated by responses from the clientele (Chapter 5 ). One wonders whether clients of the public service have excessive expectations or whether the respondents to this survey are the anomalies in the public service.

Brehm and Gates (1997) concluded that some federal employees preferred pecuniary rewards others expressed very strong functional and solidary preferences. Tables 4-5 - 4-7 depict responses of Ghanaian bureaucrats on the impact of solidary, functional and pecuniary rewards on the work performance of bureaucrats.

To determine the impact of pecuniary motives, respondents were asked to indicate how well the statements in Table 4-5 applied to them. A majority of respondents were satisfied with their chances of getting a promotion and indicated that fringe benefits and salary were important to them. This finding was true for both American and Ghanaian bureaucrats however Americans were more likely to value fringe benefits than their Ghanaian counterparts did. It may be that few Ghanaian bureaucrats receive any fringe benefits. This might explain why a majority of respondents $(58.1 \%)$ did not agree with this statement. Respondents also indicated that access to a computer, internet service and a secretary were important at the workplace. Computers and internet access are a necessity in the Western world. However in a developing country like Ghana, access to computer, internet and a secretary are viewed as status symbols. Most 
respondents agreed with the statements measuring pecuniary preferences, indicating that they play a vital role in bureaucratic practice.

Table 4-5. Impact of Pecuniary Motives on Bureaucratic Practice (Percent)

\begin{tabular}{|c|c|c|c|c|c|c|c|c|c|c|c|}
\hline & & $\begin{array}{l}\text { Strongly } \\
\text { Agree } \\
5 \\
\text { Ghana }\end{array}$ & US & $\begin{array}{l}\text { Agree } \\
4 \\
\text { Ghana }\end{array}$ & US & $\begin{array}{l}\text { Neutral } \\
3 \\
\text { Ghana }\end{array}$ & US & $\begin{array}{l}\text { Disagree } \\
2 \\
\text { Ghana }\end{array}$ & US & $\begin{array}{l}\text { Strongly } \\
\text { Disagree } \\
1 \\
\text { Ghana } \\
\end{array}$ & US \\
\hline $4-5.1$ & $\begin{array}{l}\text { I am satisfied } \\
\text { with my } \\
\text { chances for } \\
\text { getting a } \\
\text { promotion }\end{array}$ & 26.5 & $\begin{array}{l}53 . \\
2\end{array}$ & 40.2 & $\begin{array}{l}23 . \\
0\end{array}$ & 13.7 & $\begin{array}{l}17 . \\
8\end{array}$ & 12.0 & 3.0 & 4.3 & 3.0 \\
\hline $4-5.2$ & $\begin{array}{l}\text { The fringe } \\
\text { benefits I } \\
\text { receive are } \\
\text { important to } \\
\text { me }\end{array}$ & 18.8 & $\begin{array}{l}38 . \\
9\end{array}$ & 23.1 & $\begin{array}{l}27 . \\
1\end{array}$ & 17.1 & $\begin{array}{l}25 \\
6\end{array}$ & 17.1 & 4.7 & 16.2 & 3.8 \\
\hline $4-5.3$ & $\begin{array}{l}\text { The salary I } \\
\text { receive is very } \\
\text { important to } \\
\text { me }\end{array}$ & 39.3 & & 33.3 & & 4.3 & & 9.4 & & 6.8 & - \\
\hline \multicolumn{12}{|c|}{ 4-5.4 The presence of the following resources at my work place is very important to me: } \\
\hline b) & Internet service & 25.6 & & 28.2 & & 14.5 & & 5.1 & & 6.0 & - \\
\hline c) & Secretary & 18.8 & & 35.9 & & 17.9 & & 5.1 & & 8.5 & - \\
\hline
\end{tabular}

Table 4-6 depicts Likert scale responses to questions about the impact of peers on work performance. These questions were asked to determine the extent to which solidary preferences shape employees' work performance. There are no comparable results from Brehm and Gates as a result this discussion will focus solely on Ghanaian bureaucrats. On the whole respondents did report some peer influence. A majority of them felt they would gain respect from the colleagues 
when they worked hard while a majority were satisfied with the level of respect they currently enjoyed with their colleagues. It does seem however that more respondents do not spend time with colleagues outside of the work setting. The age for respondents ranged from 45 to 65 . At this age, it is likely that respondents are married with children. It is intuitive then that they would spend time with their families when they are out of work rather than their peers.

Table 4-6. Impact of Peers on Work Performance of Public Servants (Percent)

\begin{tabular}{|c|c|c|c|c|c|}
\hline & $\begin{array}{l}\text { Strongly } \\
\text { Agree } \\
5\end{array}$ & $\begin{array}{l}\text { Agree } \\
4\end{array}$ & $\begin{array}{l}\text { Neutral } \\
3\end{array}$ & $\begin{array}{l}\text { Disagree } \\
2\end{array}$ & $\begin{array}{l}\text { Strongly } \\
\text { Disagree } \\
1\end{array}$ \\
\hline $\begin{array}{l}\text { 4-6.1 My job requires that I work closely } \\
\text { with other people }\end{array}$ & 63.2 & 29.9 & 2.6 & 1.7 & .9 \\
\hline $\begin{array}{l}\text { 4-6.2 Working hard on my job leads to gaining } \\
\text { respect from coworkers }\end{array}$ & 48.7 & 34.2 & 6.8 & 6.0 & 2.6 \\
\hline $\begin{array}{l}\text { 4-6.3 The people I work with generally do a } \\
\text { good job }\end{array}$ & 23.1 & 59.0 & 6.8 & 6.9 & .9 \\
\hline $\begin{array}{l}\text { 4-6.4 I am satisfied with the respect I receive } \\
\text { from the people I work with }\end{array}$ & 33.3 & 50.4 & 5.1 & 4.3 & 3.4 \\
\hline $\begin{array}{l}\text { 4-6.5 I like coming to work because of my } \\
\text { coworkers }\end{array}$ & 7.7 & 17.1 & 14.5 & 32.5 & 22.2 \\
\hline $\begin{array}{l}\text { 4-6.6 I often call upon my colleagues for help } \\
\text { on problems which may arise in the } \\
\text { course of my work }\end{array}$ & 32.5 & 49.6 & 6.0 & 6.0 & 2.6 \\
\hline $\begin{array}{l}\text { 4-6.7 I spend a lot of time with people in my } \\
\text { department outside of working hours }\end{array}$ & 3.4 & 15.4 & 24.8 & 38.5 & 15.4 \\
\hline $\begin{array}{l}\text { 4-6.8 I often take my lunch with other people I } \\
\text { work with }\end{array}$ & 4.3 & 16.2 & 32.5 & 31.6 & 12.8 \\
\hline
\end{tabular}

The low salary level obliges most employees to have second or third jobs. This leaves them little time to socialize with colleagues out of the office. Statement 4-6.8 also demonstrates that a majority of respondents do not take their lunch frequently with their peers. In Ghana, most workplaces do not have cafeterias. This is largely because employees have easy access to food 
hawkers, chop bars and food-stands that spring up near work places. The plethora of choices available to employees guarantees that individuals may not meet their colleagues during lunch.

Ghanaian public servants therefore appear to interact with colleagues during regular business

hours. Beyond that, solidary motives play a limited role in shaping employee behavior.

Table 4-7. Impact of Functional Motives on Work Performance of Ghanaian Public Servants (Percent)

\begin{tabular}{|c|c|c|c|c|c|c|c|c|c|c|}
\hline & \multicolumn{2}{|c|}{$\begin{array}{l}\text { Strongly } \\
\text { Agree } \\
5\end{array}$} & \multicolumn{2}{|l|}{ Agree } & \multicolumn{2}{|l|}{ Neutral } & \multicolumn{2}{|c|}{ Disagree } & \multicolumn{2}{|c|}{$\begin{array}{l}\text { Strongly } \\
\text { Disagree } \\
1\end{array}$} \\
\hline & Ghana & US & Ghana & US & Ghana & US & Ghana & US & Ghana & $\overline{\mathrm{US}}$ \\
\hline $\begin{array}{l}\text { 4-7.1 The amount of } \\
\text { work expected of } \\
\text { me, on my job, is } \\
\text { just right }\end{array}$ & 23.1 & - & 51.3 & - & 12.0 & - & 6.8 & - & 4.3 & - \\
\hline $\begin{array}{l}\text { 4-7.2 In general, I like } \\
\text { working in this } \\
\text { department }\end{array}$ & 23.1 & - & 51.3 & - & 11.1 & - & 9.4 & - & 3.4 & - \\
\hline $\begin{array}{l}\text { 4-7.3 I enjoy doing my } \\
\text { work for the } \\
\text { personal } \\
\text { satisfaction it } \\
\text { gives me }\end{array}$ & 32.5 & 25.2 & 39.3 & 59.3 & 9.4 & 7.7 & 13.7 & 6.2 & 3.4 & 1.6 \\
\hline $\begin{array}{l}\text { 4-7.4 Working hard on } \\
\text { my job leads to } \\
\text { good job } \\
\text { performance }\end{array}$ & 60.7 & - & 29.9 & - & 2.6 & - & 1.7 & - & 2.6 & - \\
\hline $\begin{array}{l}\text { 4-7.5 It is important } \\
\text { that I get the } \\
\text { chance to } \\
\text { accomplish } \\
\text { something } \\
\text { worthwhile }\end{array}$ & 54.7 & 8.1 & 30.8 & 42.6 & 6.8 & 23.9 & .9 & 17.5 & 2.6 & 8.0 \\
\hline
\end{tabular}

Table 4-7 portrays responses to questions that demonstrate the extent to which public servants derive personal satisfaction from public service. These responses would enlighten observers about the role of functional motives in bureaucratic practice. A majority of respondents 
concurred with statements that functional motives exist. Both American and Ghanaian bureaucrats corroborated with statements such as "I enjoy doing my work for the personal satisfaction it gives to me"; "It is important that I get the chance to accomplish something worthwhile"; all hinting at the presence of public service motivation among American and Ghanaian public servants. Responses to questions on functional motives also serve to demonstrate that Ghanaian public servants see themselves as effective employees. It appears that like American bureaucrats functional, solidary and pecuniary benefits are some motivators of bureaucratic behavior of Ghanaian bureaucrats.

Table 4-8. Impact of Type of Organization \& Ruling Government on Working Style (Percent)

\begin{tabular}{|c|c|c|c|c|c|}
\hline & $\begin{array}{l}\text { Strongly } \\
\text { Agree } \\
5\end{array}$ & $\begin{array}{l}\text { Agree } \\
4\end{array}$ & $\begin{array}{c}\text { Neutral } \\
3\end{array}$ & $\begin{array}{c}\text { Disagree } \\
2\end{array}$ & $\begin{array}{c}\text { Strongly } \\
\text { Disagree } \\
1\end{array}$ \\
\hline $\begin{array}{l}\text { 4-8.1 My working style will be different if I } \\
\text { worked in another government } \\
\text { ministry }\end{array}$ & 9.4 & 22.2 & 11.1 & 33.3 & 22.2 \\
\hline $\begin{array}{l}\text { 4-8.2 I don't care what party is in power, my } \\
\text { work effort and ethic will be the same. }\end{array}$ & 59.8 & 35.0 & 2.6 & 1.7 & 0 \\
\hline $\begin{array}{l}\text { 4-8.3 It does not matter if the government is } \\
\text { democratic or military- my working } \\
\text { style does not change }\end{array}$ & 42.7 & 45.3 & 2.6 & 6.0 & 2.6 \\
\hline
\end{tabular}

Chapter 2 demonstrated that the Ghanaian bureaucracy has been shaped by the military and civilian regimes that have governed since independence. The statements in Table 4-8 portray respondents' perceptions about the impact of type of government and type of organization on their working style. A majority of respondents stated that their working style will not be different if they worked in another government ministry. Respondents did not also agree that their work effort will be affected by the party or government in power. Majority of the respondents had only been in the public service for less than ten years, and this may explain this response as most of 
the employees began working in the service after 1996, and Ghana has not experienced any political turmoil since 1992. One would have expected that the change from Rawlings to Kuffour might have impacted work behavior of respondents. A reason for this could be because the majority of respondents were lower level employees, a group that is distant from the political leadership and policy making.

\section{Public Service Motivation}

I supplemented the survey with personal interviews with senior level officials in the civil service in order to explore the role of public service motivation (PSM) on bureaucratic practice. This section begins with the summary of a discussion with Mr. Akwei Allotey, director of the Ghana Civil Service on his perceptions about motivations of civil servants. Allotey noted that civil servants have become apathetic because they believe Ghanaians (citizens and government alike) criticize their actions regardless of how hard they work. He remarked that successes achieved by civil servants in policy initiation are claimed by political officials while accusing fingers are pointed at the former when problems arise. As a result, the bureaucracy's work is not appreciated which translates into low morale and a negative attitude towards their job.

Allotey explained why most civil servants stayed with the service with such poor conditions of service. He observed that the different categories of workers in the civil service have different reasons for staying in the service; however every employee likes the security it provides. Allotey noted that the executives stay in the civil service because of the prestige that is associated with their position. In addition, there are perks that come with the position such as subsidized accommodation, an official car, and the opportunity to travel out of the country for workshops. Another reason why they remain in the civil service is that top-level employees have spent most of their working lives in the civil service and have specialized in particular areas, making it unappealing for them to retrain in a new area. Allotey added that some top-level 
officials do have a passion for the civil service and stay on for that reason. Managers constitute the specialized grades (e.g., policy analysts, engineers, geologists and system analysts) and according to Allotey, have the least permanency in the civil service. The middle level constitute the university graduates who enter the service usually as a last option, to gain some years of working experience so they can obtain better job packages elsewhere. Similar to executives, operators are the most permanent employees. These employees do not have college education but rather high school education or below. With minimum qualifications, conditions of service are likely to be poor regardless of the organization they work in. Most importantly, there are opportunities for advancement in the civil service because of the availability of training which makes it a more attractive place to stay. Some civil servants stay on in the service because there are no alternative jobs available.

In an effort to measure the existence of PSM in Ghanaian bureaucrats, respondents asked the following question: "On the following list there are various aspects of a job. Please circle the one you personally consider very important in a job." This question relates to any job and not the public service in particular. If respondents had PSM, they would be attracted to jobs that provide the opportunity to give back to society. Table 4-9 demonstrates that a majority of respondents wanted a job that offered advancement opportunities. Following close behind is job security as a determinant. This corroborates previous studies (Rainey, 1982; Wittmer, 1991; Massey \& Brown, 1998; Gabris and Simo, 1995; Houston, 2005) about public servants. Few respondents valued a job that is useful to society. Responses to this question do not portray public servants in Ghana as having PSM. Ghana has a weak economy where citizens struggle to make ends meet. It is to be expected that prospective job seekers would primarily look for careers with advancement opportunities, which translates into higher incomes. 
Table 4-9. Which of the Following Aspects of a Job are Attractive to Respondents?

\begin{tabular}{lc} 
Job Attractions & Percentage \\
\hline Advancement Opportunities & 42.0 \\
Job Security & 35.7 \\
Useful to society & 10.7 \\
High Income & 9.8 \\
Interesting job & 1.8 \\
Total & 100.0 \\
\hline
\end{tabular}

In Table 4-10, respondents were presented with a list of benefits to be derived from employment in the public service in particular. Respondents were to select the option they believed was the most advantageous. This question was to determine whether public servants had PSM. While a majority of respondents chose job security as the primary benefit, 26.9\% of 2006 respondents believed that employment in the public service allowed them to provide services to citizens and develop Ghana. Respondents from 2006 differ substantially from their 1969 counterparts as Price's respondents overwhelmingly favored job security $(74.2 \%)$ and other features of the job that brought personal rewards to the respondent. Price's respondents were also ten times more likely than 2006 respondents to dislike government work. It appears that 2006 bureaucrats do have PSM while 1969 respondents are more self-interested. This finding is logical if one considers the assertion that familial expectations were greater for 1969 respondents than they were for 2006 respondents. In Chapter 5, I demonstrate that "significant others" in 2006 have moderated their expectations of public servants. This might be a reason why 2006 public servants are able to look beyond personal and familial interests. When responses in Tables 4- 9 and 4- 10 are combined, PSM appears to very weak among respondents. Few public servants were attracted to jobs that were useful to society. However, when respondents were forced to 
think about their current positions in the public service, they were more likely to value aspects of government employment that allowed them to render services to the citizenry.

Table 4-10. Perceptions of Public Servants about Advantages of Government Work (Percent)

\begin{tabular}{lcc}
\hline Advantages & $\begin{array}{c}2006 \\
\text { Respondents } \\
\text { Percent }\end{array}$ & $\begin{array}{c}\text { Price's } \\
\text { Respondents } \\
\text { Percent* }\end{array}$ \\
\hline Security & 59.1 & 74.2 \\
Material benefits & 1.7 & 15.2 \\
Upward mobility & 8.7 & 4.4 \\
Intrinsic job satisfaction & 1.7 & 3.5 \\
$\begin{array}{l}\text { Develop Ghana } \\
\text { Services for people }\end{array}$ & 21.7 & 1.6 \\
& 5.2 & 0.7 \\
$\begin{array}{l}\text { Don't like government } \\
\text { work }\end{array}$ & 1.7 & 15.2 \\
Total & 100.0 & 114.8 \\
\hline
\end{tabular}

*Percent total more than 100 for Price's column because multiple reasons were permitted.

Respondents were asked what career choice they would suggest to an intelligent young man. The goal of the question was to determine whether or not respondents had a strong commitment to the public service. An individual who is committed to the institution is likely to recommend it to someone else whereas the individual who is unhappy with his or her job is likely to discourage others from following in his or her track. Sixty percent of 2006 respondents suggested a career in the professional field (e.g., lawyer or doctor) (Table 4-11). 
Table 4-11. Suggestions from Public Servants for an Intelligent Young Man (Percent)

\begin{tabular}{llc}
\hline $\begin{array}{l}\text { Career } \\
\text { Choices }\end{array}$ & $\begin{array}{l}\text { 2006 Respondents } \\
\text { Percent }\end{array}$ & $\begin{array}{l}\text { 1969 Respondents } \\
\text { Percent }\end{array}$ \\
\hline Civil Service & 11.5 & 9.2 \\
Professional & 60.2 & 36.4 \\
Accounting & 8.0 & 5.3 \\
Business & 6.2 & 15.0 \\
Skilled Technician & 4.4 & 12.8 \\
Agriculturalist & 3.5 & 7.6 \\
Teacher & 3.5 & 5.1 \\
Military & 2.7 & 7.7 \\
Other & & 0.9 \\
Total & 100.0 & 100.0 \\
\hline
\end{tabular}

Only $11.5 \%$ of respondents suggested the civil service. Respondents who did not choose the civil service were asked to explain their choice. Most of them cited factors such as: lack of advancement opportunities, lack of motivation, lack of initiative, or low salary structure. These findings are similar to Price's. A majority of responses in Price's study suggested non civil service careers with only $9.2 \%$ choosing public service for their mentee. If public servants do not feel fulfilled in their career track, it is unlikely that they will encourage an intelligent young man to pursue a career in that field. Few respondents in 1969 or 2006, gave high ratings to the civil service as a career option indicating that their commitment to the public service may not be motivated by PSM. 
Table 4-12. Conditions under which Public Servant Might Leave Public Service (Percent)

\begin{tabular}{lll}
\hline $\begin{array}{l}\text { Reasons why Respondent might leave } \\
\text { Public Service }\end{array}$ & $\begin{array}{l}2006 \text { Respondents } \\
\text { Percent }\end{array}$ & $\begin{array}{l}\text { Prices' Respondents } \\
\text { Percent }\end{array}$ \\
\hline Private business, lower salary & 3.6 & N/A \\
Private business, higher salary & 75.9 & 72 \\
Private business, same salary & 1.8 & N/A \\
I will not leave & 18.8 & 27 \\
Total & 100.0 & \\
& $(N=63)$ & \\
\hline
\end{tabular}

Respondents were asked under what conditions they will leave the public service. I expected that respondents with a high public service ethic would be unwilling to leave the public service whereas those with pecuniary motives will leave for jobs with better monetary rewards.

Reactions of 1969 and 2006 respondents depict a majority of respondents that are prepared to leave the civil service if they were offered a job in the private industry with more money. For both year groups, the second common response was from respondents who said they would not leave at all. Price whose survey instrument provided respondents the opportunity to explain their choice, noted that the respondents who chose to remain in the public service did so for security reasons. Respondents in the 2006 survey that chose "staying in the civil service" were unwilling to move to a private industry no matter how well established because adverse economic conditions could affect a private organization's longevity whereas government agencies were more permanent. Some of Price's respondents stated that private firms could dismiss them arbitrarily whereas in the public service, they were tenured. This practice still holds in 2006. 
Responses to this question challenge the assertion that PSM plays a strong role in the behavior of Ghanaian public servants. The responses depict public servants, a majority of whom will leave the public service for better remuneration and a minority who will stay for security reasons and not because they valued public service. That said, in Table 4-10, $21 \%$ of respondents said an advantage of government work was because it allowed the opportunity to develop Ghana. Combining the varied responses from public servants then, makes it impossible to rule out the existence of PSM among Ghanaian bureaucrats.

Perceptions of Public Servants about Expectations from Significant Others

This section examines the public servants' perceptions of expectations from their significant others. Responses are compared to Price's findings to determine if perceptions have changed over time.

Respondents were presented with the following scenario: A public servant, who is from Accra and lives in Accra with his family and friends, is officially informed that he is to be transferred from Accra to a new post in Tamale. The public servant is from Accra and has all his friends and relatives there. The public servant is also looking after his aged parents who are too old to move to the North with him. For the above reasons, the public servant does not want to be transferred to Tamale and goes to the head of department who happens to be the cousin and requests that he be kept in Accra.

In this scenario, showing preferential treatment to a family member contravenes the "first come, first served" standard of bureaucratic universalism and is equal to particularistic behavior. Should the head of department give precedence to the family role-set, universalistic norms of public service personnel policy are violated. On the other hand, giving priority to the organizational role-set might put the family in dire straits. Table 4-13 captures the responses to the imaginary scenario. Comparisons are not made with 1969 respondents because Price asked 
open ended questions about the head of department's expected behavior. 2006 respondents were presented with options and were asked to choose one response in order to facilitate the comparison of responses.

Almost $90 \%$ of respondents felt that the head of department will keep his cousin in Accra although they varied with regard to the rational for the decision. Only $11 \%$ thought the head of department would send his cousin to Tamale. Clearly a majority of respondents believe family members come first.

In addition to predicting the head of department's behavior, respondents were asked to determine how family members would expect the head of department to behave. A majority of respondents believed family members would expect the head of department to keep their father in Accra with $21.8 \%$ of respondents positing that the head of department would be expected to follow the rules. Price who employed open-ended question recorded that $85 \%$ of the sample believed the departmental head would be expected by his relatives to overturn an official decision and arrange to nullify his cousin's transfer (Table 4-14).

Table 4-13. Head of Department's Decision Concerning Cousin's Transfer (Percent)

\begin{tabular}{ll}
\hline Behavior of Head of Department & $\begin{array}{l}2006 \text { Respondents } \\
\text { Percent }\end{array}$ \\
\hline Accra, Because of Relation & 17.3 \\
Accra, Valid Reasons & 52.7 \\
Accra, Fear & 16.4 \\
North & 11.8 \\
Accra, bribery & .9 \\
Total & 100.0 \\
& $(N=63)$ \\
\hline
\end{tabular}


When responses from Table 4- 13 and 4-14 are combined, it becomes evident that public

servants think about the reaction of their family members when making a decision especially if it concerns another family member.

The respondents were further asked to imagine the reaction of the family members if the head of department transferred the cousin to the North ${ }^{2}$ (Table 4- 15). Once again, unlike Price who allowed open ended responses, 2006 respondents were limited to three options. A majority of the respondents believed that the family would be very upset while a minority believed the family members would understand. In a society where family is very important, individuals would not like to antagonize their family members for which reason they will take the family's feelings into consideration when making certain decisions. Price (1975) posited that relatives fail to recognize the existence of conflicting role demands and will interpret the head of department's refusal to help as a sign of selfishness (1975). According to Price (1975), 43\% of respondents felt the civil servant would be thought of as "wicked, bad, cruel or hard-hearted man". Other adjectives that Price's (1975) respondents used to describe the head of department were "ungrateful", "inconsiderate" and "selfish".

Table 4-14. Expectations of Significant Others Regarding Head of Department's Decision to Transfer Cousin (Percent)

\begin{tabular}{lll}
\hline Family's Expectations & $\begin{array}{l}2006 \\
\text { Respondents } \\
\text { Percent }\end{array}$ & $\begin{array}{l}\text { Prices' Respondents } \\
\text { Percent }\end{array}$ \\
\hline Family insist Accra & 78.2 & 85 \\
Follow Rules & 21.8 & N/A \\
Total & $\begin{array}{l}100.0 \\
(N=63)\end{array}$ \\
& & \\
\hline
\end{tabular}

${ }^{2}$ The Northern part of Ghana has greater economic deprivation as compared to the South, particularly Accra. In addition to that, the North is far from Accra making frequent travel between the two areas difficult. 
Table 4-15. Reaction of Significant Others if Head of Department Transfers Cousin to the North (Percent)

\begin{tabular}{ll}
\hline Family's Reaction & $\begin{array}{l}2006 \text { Respondents } \\
\text { Percent }\end{array}$ \\
\hline Family understands HOD & 9.8 \\
Family, little upset & 31.3 \\
Family, very upset & 58.9 \\
Total & 100.0 \\
\hline
\end{tabular}

Service Orientation in Public Servants

Price posited that for public servants to be effective service providers, they ought to have a service orientation. Consequently, officials should not conceive of the office as their personal possessions to be exploited. Price argued that there is a strong temptation for public servants to exploit their positions because of the authority the position allows them to wield over their clients. To counteract these temptations he maintained that positive incentives, whether within the institution or outside must be put in place. One such incentive can be provided by clients who come to the organization expecting that a service be provided. When clients lack such an expectation, they reinforce anti-service orientations that public servants might profess. Price maintained that clients in transitional societies such as Ghana, lack this service orientation because of 1) "their low income conditions 2) lack of national and political integration which hinders' the individual's ability to see him or herself as a citizen and to expect the rights that a state accords to its citizens; and 3) lack of role differentiation thereby forcing clients to view public servants as personally possessing the power and services attached to their offices" (1975, p. 132). Price concluded that if government services are viewed as privileges, then clients have to pander to public servants in order for them to receive these privileges. 
In order to measure the extent to which public servants conceived of their positions as personal property to be exploited, they were asked what the best alternative would be if a client needed service provided from a government agency. Responses to this question will enable the researcher to observe the extent to which public servants acknowledged the rights of citizens. Price asked the clientele respondents, rather than public servants, to provide answers to this question. I asked public servants this question in order to compare responses with clientele choices. This would help determine if public servants and clientele have similar views about the rights of the latter. Below are the options available to the client and public servants were to choose which alternative they believed will be the best for the client to receive prompt and efficient service.

Table 4-15. Options Available to Clients in Need of Public Service (Percent)

\begin{tabular}{ll}
\hline Alternatives & $\begin{array}{l}\text { 2006 Respondents } \\
\text { Percent }\end{array}$ \\
\hline Relative in Government & 20.2 \\
Direct to office & 64.2 \\
Friend of government & 15.6 \\
Total & 100.0 \\
& $(N=63)$ \\
\hline
\end{tabular}

A majority of public servants surveyed felt the client should just go to the office and state his problem (Table 4-15). According to this finding, public servants acknowledge and respect the rights of the clients they serve. It is worth noting that of the remaining two alternatives, public servants believed a family member would be more helpful than a friend. This supports the 
assertion that family members expect to appropriate the benefits that come with the public servant's position.

\section{Conclusion}

This chapter set out to understand variations in motivations of Ghanaian bureaucrats, to examine the impact of PSM on the performance of public servants and to examine public servant's perceptions about the expectations of their significant others. 1969 responses have been compared with 2006 survey responses to determine if clients in 2006 have moderated their expectations of their family members. Generally, 2006 respondents are more understanding of the bureaucrat's choice for universalism. The chapter also discussed public servants' understanding of the rights of the clients they serve and the extent to which they respect these rights. The responses of public servants to this question will be compared to responses from clients in Chapter 5.

Analysis of responses provided by public servants demonstrates that pecuniary, functional and solidary preferences have an impact on public servants behavior. In addition, Ghanaian public servants believe they work hard, responses that are similar to Brehm and Gates' findings. It appears that PSM is weak among public servants and this is apparent even when comparing 1969 and 2006 respondents. Still, public servants expect the clientele they serve to demand their rights when they approach the public service and seem to believe if they do they will be served. The next chapter focuses on the clientele survey to examine their expectations of their significant others who work in the public service. 


\section{Chapter 5: Results of the Clientele Survey}

This chapter analyzes responses from the Clientele Survey. The clientele are in two groups-literate and non-literate group. The first part of this chapter discusses the demographics of the respondents solicited for this survey. The second part analyzes their responses to the survey questions while comparing findings from this study to Price's in order to verify changes in perceptions. The literate and non-literate respondents were presented with similar questions with the exception of a few questions that were unique to each group. In cases where both groups were asked similar questions, comparisons were made to see if variations may be found in responses between the groups. Respondents of the 2006 survey are also compared to 1969 clientele to measure changes that have taken place.

\section{Literate Clientele}

Literate respondents were disproportionately male. A majority of respondents were solicited from the political science department of the University of Ghana. In Ghana, politics is considered a man's domain. This might explain the gender composition of the sample. The ethnic distribution of respondents is reflective of the general population, with Akans the largest ethnic group, followed by the Mole Dagbani, Ewes in third position and the Gas in the minority. The education distribution among the respondents is not reflective of the general population. College seniors were disproportionately sampled among the literate clientele. In the same vein, unemployed respondents are oversampled in this study because more than $90 \%$ of respondents were college students. Table 5-1 illustrates descriptive characteristics of literate respondents. 
Table 5-1. Characteristics of Literate Clientele

Description

Percent

Gender

Male

Female

Ethnic affiliations

Akan

Ewe

$\mathrm{Ga}$

Northern region

Other

Level of Education

Seniors in college

Non-college respondents

Bachelor's degree

Associate's degree

High school degree

Employment history

Currently employed $\quad 42.0$

Currently unemployed $\quad 58.0$

Currently employed in public service $\quad 28.0$

Have a history of working in public service 39.0

Travel experience

Travel around Africa

Travel out of Africa

19.5

Have not left Ghana

49.0

\section{Non-Literate Clientele}

Sixty-three interviews were collected from the non-literate group. Of these, $16 \%$ were Akan, $13 \%$ were Ewe and 34\% were from the Ga tribe. Ninety-four percent of the respondents 
lived in Accra, the capital and $6 \%$ lived in the Eastern Region. The non-literate clientele were disproportionately female (81\%). Respondents were asked about their level of fluency in the English language because this study hypothesized that contact with modernizing influences, for instance formal education, had an impact on respondents' attitude about the public service. English is the language of instruction at the primary level through to the tertiary level. In some areas, primary schools may instruct students in local languages.. All high schools however use English as the medium of instruction. An individual who cannot communicate in English is therefore one who has not had high school education. Some individuals without any formal education may be able to speak "broken" English, which sounds like pidgin. About $21 \%$ of the respondents could not speak any English, 38\% could speak a little English, 36.5\% could speak English fairly well and 4.8\% spoke English very well. Respondents appeared uncomfortable with the question and may have indicated that they could speak a little English when in fact they could not or only knew a few phrases.

Respondents were asked about the ability of their parents to communicate in English. Price's findings demonstrated that households where parents spoke English were more likely to have universalistic expectations of public servants. Respondents for this study were therefore asked to indicate their parents' level of fluency in English. A majority of the respondents had fathers who were not literate in English. Only 22\% of the fathers could communicate in English. $55.6 \%$ of the respondents had mothers who were not literate in English while $41.3 \%$ had mothers who could communicate in English. 
Table 5-2. Characteristics of Non-Literate Clientele

Description Percent

Gender

Male $\quad 81.0$

$\begin{array}{ll}\text { Female } & 19.0\end{array}$

Ethnic affiliations

$\begin{array}{ll}\text { Akan } & 16.0\end{array}$

$\begin{array}{ll}\text { Ewe } & 13.0\end{array}$

$\mathrm{Ga} \quad 34.0$

Domicile

$\begin{array}{ll}\text { Accra } & 94.0\end{array}$

$\begin{array}{ll}\text { Nsawam } & 6.0\end{array}$

Fluency in English

Can speak no English $\quad 21.0$

Can speak a little English $\quad 38.0$

Can speak English fairly well $\quad 36.5$

Can speak English very well $\quad 4.8$

Parents' fluency in English

Father is not literate in English $\quad 78.0$

Father can communicate in English $\quad 22.0$

Mother is not literate in English $\quad 55.6$

Mother can communicate in English 41.3 


\section{Familial Expectations}

A set of statements, aimed at exploring the perceptions of literate respondents about their obligations to their families when they graduate and their perceptions of the civil service, were presented to literate respondents asking them to agree or disagree with the statement. The expectations that family members have of respondents is expected to affect their choice of employment after graduation. Price had a list of open-ended questions for the respondents. I transformed his questions into close ended question therefore I am unable to make direct comparisons to Price.

Table 5-3. Literate Respondents' Perceptions about Employment after Graduation (Percent)

\begin{tabular}{|c|c|c|c|c|c|c|}
\hline & $\begin{array}{l}\text { Strongly } \\
\text { Agree } \\
5\end{array}$ & $\begin{array}{c}\text { Agree } \\
4 \\
\end{array}$ & $\begin{array}{c}\text { Neutral } \\
3\end{array}$ & $\begin{array}{c}\text { Disagree } \\
2\end{array}$ & $\begin{array}{c}\text { Strongly } \\
\text { Disagree } \\
1\end{array}$ & Missing \\
\hline $\begin{array}{l}\text { When I begin to earn a } \\
\text { salary, I will be under } \\
\text { obligation to my family } \\
\text { because of the assistance } \\
\text { they gave during my } \\
\text { education and upbringing }\end{array}$ & 40.5 & 41.5 & 6.7 & 8.2 & 3.1 & 0 \\
\hline $\begin{array}{l}\text { I will like to work in the } \\
\text { public service when I } \\
\text { graduate }\end{array}$ & 11.3 & 26.2 & 34.9 & 15.9 & 11.8 & 0 \\
\hline $\begin{array}{l}\text { I will work in the public } \\
\text { service if the salary is good }\end{array}$ & 33.8 & 39.5 & 14.9 & 6.7 & 3.1 & 2.1 \\
\hline $\begin{array}{l}\text { I will not work in the } \\
\text { public service even if the } \\
\text { salary seems good }\end{array}$ & 4.6 & 5.1 & 24.6 & 44.6 & 19.0 & 2.1 \\
\hline $\begin{array}{l}\text { My family will be upset if I } \\
\text { worked in the public } \\
\text { service }\end{array}$ & 2.6 & 6.2 & 19.5 & 33.3 & 38.5 & 0 \\
\hline
\end{tabular}

Table 5-1 demonstrates that a majority of educated respondents (82\%) agreed that when 
they began to earn a salary they would be under obligation to their families because of the assistance received during their education. This supports Price's assertion that in communitarian societies like Ghana, the extended family has expectations of their members. This is particularly true for the nuclear family unit where parents are not expected to take the initiative to ask their employed children for financial assistance. The latter are expected to make monetary remittances to their parents when they begin earning a salary, and help take care of younger siblings who may still be living at home with the parents. Society frowns on individuals who shirk their financial responsibility to family members when they are financially capable of helping out. A plurality $(37.5 \%)$ posited that they would like to work in the public service when they graduated. This number increased substantially when salary was introduced. A good number of respondents $(73.3 \%)$ were more willing to work in the public service if the salary was good. When asked if their family will be upset if they worked in the public service, $71.8 \%$ disagreed. It appears that literate respondents, most of who were in college, were not averse to working in the public service. Clearly they preferred employment with any organization where they could earn good income, a reaction that is understandable as financial obligations increase after they start earning income. Respondents indicated that their families were not averse to public service work either. On the whole, respondents were not against employment in the public service

In order to get a feel for family pressures Price presented an imaginary scenario to his respondents which is borrowed below:

Your father is a public servant who is posted in Accra, and he has just got notice that he will be transferred to a new post in Tamale. Your entire family lives in Accra, and if your father must move your family life will be seriously disrupted. Now, your mother's sister is married to a man 
who is the head of your father's department, and therefore he has the power to arrange to have your father keep his Accra post.

Respondents were asked to predict the behavior of the head of department. Price employed open-ended questions and surmised that $80 \%$ of Price's literate respondents believed that the family would expect the head of the department to keep father in Accra.

Table 5-4. 2006 Respondents Prediction of Head of Department's Behavior (Percent)

\begin{tabular}{lllll}
\hline & $\begin{array}{l}2006 \\
\text { Public } \\
\text { Servants }\end{array}$ & $\begin{array}{l}\text { Price } \\
\text { Literate }\end{array}$ & $\begin{array}{l}\text { 2006 Non- } \\
\text { literate } \\
\text { Clientele }\end{array}$ & $\begin{array}{l}\text { 2006 } \\
\text { Educated } \\
\text { Clientele }\end{array}$ \\
\hline Keep father in Accra & 78.2 & 80 & 81.0 & 61.0 \\
Follow rules of transfer & 21.8 & - & 17.5 & 37.4 \\
Missing & - & - & 1.6 & 1.5 \\
Total & 100.0 & & 100.0 & 100.0 \\
$\chi 2(\mathrm{DF}=1, \mathrm{~N}=254)=8.707, \mathrm{p}<.01$ & $(N=63)$ & $(N=63)$ & $(N=195)$ \\
\hline
\end{tabular}

A majority of the literate and non-literate respondents expected the head of department to keep their "father" in Accra (Table 5- 4). More non-literate respondents (81\%) favored this view. Chi-square tests show a significant $p$-value $(p<.01)$, indicating that education makes a difference in expectations of the head of department. It appears that public servants are aware of the expectations of their significant others.

Respondents in 2006 were asked what their reaction would be if the head of department transferred their cousin to the North contrary to their expectations. Price gave respondents the opportunity to give open-ended responses regarding the reaction of the family if the head of department did not keep their father in Accra. Three-fourths of the respondents stated that the 
relationship between the family and the head of department will be severely damaged if he did not keep their father in Accra. In 2006, respondents were not given the option of open-ended responses. Rather they had to make a choice from three alternatives: "Family will understand, Family will be a little upset, Family will be very upset”. For this question, clientele respondents were almost evenly split. The non-literate group was slightly more understanding of the head of the department's decision to transfer the public servant than the educated group. In as much as this percentage is almost negligible, it suggests that familial bonds may be relaxing. A number of factors may help explain why responses to that question appear counterintuitive.

Table 5-5. Family's Reaction if Head of Department Transfers Cousin to the North (Percent)

\begin{tabular}{llll} 
& & & \\
& $\begin{array}{l}2006 \text { Public } \\
\text { Servants }\end{array}$ & $\begin{array}{l}2006 \\
\text { Non-literate } \\
\text { Clientele }\end{array}$ & $\begin{array}{l}2006 \\
\text { Educated } \\
\text { Clientele }\end{array}$ \\
\hline Family will Understand & 9.8 & 38.1 & 33.8 \\
Family will be a Little Upset & 31.3 & 31.7 & 36.9 \\
Family will be Very Upset & 58.9 & 30.2 & 27.7 \\
Missing & 0 & 0 & 1.5 \\
Total & 100.0 & 100.0 & 100.0 \\
$\chi 2(\mathrm{DF}=2, \mathrm{~N}=255)=.690, \mathrm{p}>.01$ & $(N=63)$ & $(N=63)$ & $(N=195)$ \\
\hline
\end{tabular}

About $61 \%$ of the literate respondents fell within the age group, thirty and below whereas only $23.8 \%$ of non-literate respondents fell within that age group. This could mean that more literates than non-literate respondents were dependent on their parents, or in this case, father for their sustenance and as a result were more likely to feel the pinch if their father was transferred. Similarly a majority of the non-literate respondents were working. This independent source of 
income makes them less dependent on their father and by extension these respondents are more likely to understand the transfer. During the data collection process, some non-literate respondents, when asked if they will be upset if their father was sent to the North, did not acquiesce, maintaining that their father could still send them money and other necessities even though he may not be living with them.

Responses to this question in particular challenge the role of education as a variable in explaining respondents' behavior. This is corroborated by the insignificant $p$-value for the chisquare $(p>.01)$ indicating that education does not play a crucial role in attitudes toward the head of department who sends the public servant to the North.

Nonetheless, the fact that $30 \%$ of respondents in 2006 were very upset compared to $75 \%$ of 1969 respondents demonstrates that 2006 respondents are more understanding of the behavior of public servants. A number of changes in the Ghanaian economy over the years may account for the changes in opinion. For instance, the transportation system and roads have improved greatly. It is no longer a challenge to move from one part of the country to the other. Courier facilities such as FedEx, DHL and money transfer centers such as Western Union, are available throughout Ghana. Telecommunication facilities have greatly improved. During the data collection process in Ghana, it was a challenge to find an individual who did not own at least one cell phone. It can be argued that respondents, realizing they will still be able to communicate with their father, were more accepting of the separation. In the same vein, if the family members were going to be severely affected by this decision, it is very likely more respondents would have been upset that their father had to be sent to the North.

Public servants did not expect their significant others to understand the head of departments decision in favor of universalism. Almost twice as many public servants said the 
family would be upset. If perceptions of familial expectations affect behavior of bureaucrats, public servants might erroneously sacrifice universalism for particularism.

\section{Examining the Existence of Service Orientation among Ghanaians}

Price believed that deference was a feature, rife in bureaucrat-client relationships and that the degree with which it was displayed varied with the social status of the client. Individuals of higher social standing are less likely to be differential to public servants. To tap into the nature of this relationship between bureaucrat and client, respondents were asked to presume they were teaching a child how to deal with the government civil service. They were presented with a set of alternatives and were asked to choose the option that best helps to teach a child how to deal with the public service.

a) As a government employee, he is your servant, and it is his duty to give you prompt help. You should simply state what you want from him.

b) He is in a position of authority and therefore you must show proper respect if you expect help from him.

c) Although civil servants are employed to serve people like you, it is best to show respect if one wants help from them

Price interprets alternative " $a$ " as the classic service orientation; alternative "b" places the public servant in a position of authority. The last alternative depicts a client adopting an attitude of instrumental obsequiousness. Price hypothesized that a majority of the respondents would favor the second alternative which he categorizes as the "dispensatory orientation" where there is a complete absence of service orientation. In Table 5-6 Price's data shows a greater percentage of non-literate respondents supporting the service orientation, a finding that challenges the hypothesis that access to modernization makes a respondent more likely to demand service provision. The author noted that a reason for this incongruity could be because alternative "a" 
was worded differently for the two groups. Table 5-6 depicts a majority of 2006 respondents favoring teaching the child to show respect to the public servant; thus corroborating Price's findings. None of the non-literate respondents felt they would train their children to perceive the public official as a servant. Ghanaian society places a high value on deference and so it is to be expected that parents would not teach their parents to view the public official as a servant. The translation of servant into the local language carries a derogatory meaning. This might explain why none of the non-literates supported the instrumental orientation. Chi-square tests show a significant $p$-value $(p<.01)$, an indication that education plays a role in respondents' perceptions of how to train a child to deal with the public service. 2006 respondents validated 1969 responses except for non-literates in 1969 that appeared to have greater service orientation than literates.

Table 5-6. Respondents' Beliefs about Proper Orientation in the Client Role (Percent)

$1969 \stackrel{\text { Literate }}{2006 \quad 2006 \quad 1969}$

a) Service orientation

$\begin{array}{llll}14.7 & 26.3 & 0 & 20.5\end{array}$

b) Dispensatory orientation

$\begin{array}{llll}11.9 & 16.5 & 17.5 & 30.7\end{array}$

c) Instrumental orientation

$\begin{array}{llll}74.2 & 56.7 & 82.5 & 48.7\end{array}$

Not Answered

.5

100.8

$100.0 \quad 100.0$

99.9

Total

$\chi 2(\mathrm{DF}=2, \mathrm{~N}=256)=21.567, \mathrm{p}<.01$

$N=195 \quad(N=63)$

To provide further testing about the lack of service expectations among non-literate clients, they were asked to imagine they had to visit a government office to take care of some routine business that usually takes only a few minutes to transact, but respondents find 
themselves waiting three hours until the government official tells them to return the next day. Respondents were presented four alternatives to choose from:

a. I would realize that "this is the way things are," that it is to be expected, and I would come back the next day.

b. I would become angry and demand an explanation from the civil servant.

c. Becoming angry, I would demand that the civil servant serve me, and if he did not I would insist on seeing his superior or supervisor.

d. I would offer to "do something" if he would finish the business straight away.

Table 5-7. Non-literate Estimates of Their Probable Reaction to Bureaucratic Delays (Percent) 1969 Non- Literates 2007 Non-Literates

Reaction to Delays and Refusals $\quad$ Percentage Percentage
a. I will come back the next day
64.1
22.2
b. Become angry
5.1
25.4
c. Demand to see his superior
17.5
d. Bribe

Total

Cumulatively, $57.1 \%$ of 2006 respondents in Table 5-7 have a dispensatory orientation - they see public officials in position of authority. Compared with respondents from Price's study where $87.2 \%$ of the respondents appear to think that the official providing a service is giving the client a privilege. It appears that non-literate clients in 2006 are more likely to possess a service orientation than their counterparts in 1969. Since education is not responsible for the differences in opinion, I conjecture that 2006 non-literate respondents are more aware of their rights. Ghanaians believe that public servants employ delay tactics to demand bribes from clients. The 
struggling economy, coupled with low wages has forced citizens to find creative ways of stretching their income. This may help explain why non-literates, who would not like to part with unlimited funds, might become angry as there is no guarantee that the public servant would render the service when clients return the next day.

To further measure respondents perception of their rights vis-à-vis the public servant, they were asked to choose from the following alternatives, the one that would be the most effective way to get routine business successfully completed in the shortest time.

a. You go see a friend who knows the official with whom you must deal.

b. You go straight to the government office and state your business.

c. You visit the official in charge at his house prior to going to his/her office and offer to "do something".

d. You find someone to "fix things" with the responsible official.

e. You go to the office and tip the official with whom you must deal.

Price advertently added a time dimension to the scenario (i.e., "shortest possible time"). Price believed that wording the statement this way, will prompt respondents to choose alternative "b", the universalistic approach, as opposed to "a", "c" and "d" that would require the respondent expending more effort and time to find an intermediary and go to official's house. A counter argument however is, if "knowledge of a big man" (as will be demonstrated) is important in getting things done, then going through an intermediary may seem to be time consuming at the onset but may actually be time saving in the end.

It must be recalled that of the five alternatives, "b" is the universalistic approach. Price suggested that the educated group feel they can receive services at government offices because their educational attainment gives them a type of social status that non-literates might lack. 
Conversely, the non-literate group, because of their lack of formal or Western education may be more inclined to follow traditional practices that support particularistic roles. This is confirmed in Table 5-8 where literate respondents in 1969 and 2006 were more likely to choose the universalistic approach and non- literates preferred visiting the official at home. There is little difference among literate and non-literate respondents about the decision to use a friend. One would have expected more literates to choose the route. The question does not ask if respondents have a contact in the public service. It allows the respondent to assume he or she has a contact and must only decide whether to call in a favor. The assertion that literates might have more contacts is minimally supported in Table 5.8. Although respondents of both years chose "finding someone to fix things" as a fourth alternative, literates were slightly more likely to choose that approach.

Price had a larger and more varied sample size and demonstrated that as respondents (university students) went higher on the educational ladder, they were more likely to support the universalistic approach in other words, seniors were more likely to support going directly to the office than freshmen would. A majority of my sample of educated respondents $(88.7 \%)$ were college seniors. The remnant was made up of graduates of high school, two year colleges, four year colleges and a respondent with a Masters degree. The lack of variation in the literate sample utilized for this study makes it impossible to corroborate or dispute Price's finding with regards to the impact of length of stay in university on respondents' choice of particularism or universalism. Price's study found that when "routine business" was replaced with "urgent business", literate respondents were less likely to favor going the universalistic route. The percentage dropped from $46.1 \%$ to $32.2 \%$. This demonstrated that respondents believed receiving urgent services might require going back to the traditional particularistic route. 
Of the four groups, 2006 non-literates were more likely to tip the official in the office because that appears to be the norm. Most respondents may have previously adopted this approach. As the prevailing argument is that non-literates have fewer contacts, it makes sense that they will tip the official at the office.

Table 5-8. Respondents' Evaluations of Alternative Methods of Doing Business at Government Offices: Comparison of Clientele Samples (Percent)

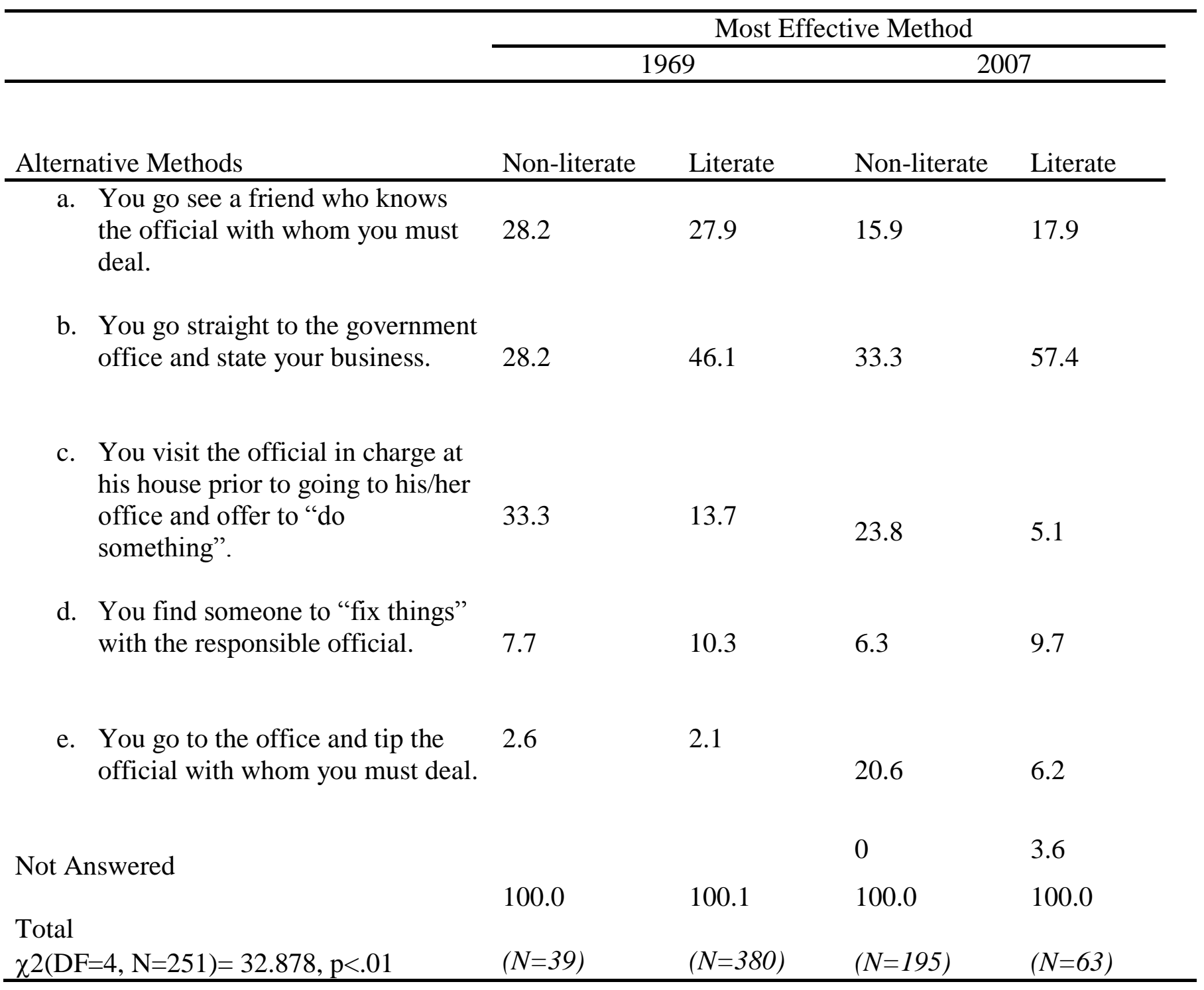


Findings in the previous table, Table 5-8 also show a majority of non-literates choosing to tip the official at the office. This practice is commonly known as "dashing", a practice that Price distinguished from "extortion, graft or payoffs" (1975, p. 117). Price defined dash as an "institutionalized mechanism for establishing a personal tie between the client and bureaucrat in a situation in which the two are strangers" (1975, p. 118). Price differentiated a dash from a bribe because the latter involved dishonorable connotations that were not altogether accurate when referring to a dash. Price (1975) distinguished dash from tip, noting that the former occurred prior to the transaction and was a prerequisite for it rather than following it as an appreciation of services rendered. Price suggested however that dash is an adaptation of a traditional behavior. He cited Robert Levine (1970) who stated that "Africans are frankly and directly concerned with the material transfer as indicative of the quality of the relationship" (p. 120). Price traced African social interaction patterns to the pre-colonial period where European merchants could trade with Gold Coasters only after they had first given customary gifts to the chiefs of the towns. Price surmised that by dashing, a personal link was established between people with no prior relationship. He narrated an encounter with one of his respondents, an elderly Ga market woman, who insisted that she preferred public servants who accepted dashes: "He gives me peace of mind-I know he will finish my business." Of the civil servant who refuses the dash, she stated "a very wicked man- he worries me, I don't know what he will do" (Price 1975, p. 120).

Price argued that as dashing was not new to Ghanaian society and was commonly practiced, it could be treated as one of the traditional practices that could be mitigated by Western influence. He therefore expected non-literates to be more likely to support dashing than the literate respondents. Price's findings corroborated his hypothesis. He found that a third of non-literate respondents supported going to the official's house and offering a dash while one- 
seventh of the university students supported this approach. This finding does not apply to alternative "e" where the client goes to the office to dash the official. Only $2 \%$ of the literate respondents and slightly more than $2 \%$ of the non-literate respondents believe going to the office to offer a dash is the best alternative. Price opined that the reason so few of his respondents supported the office dash ritual was because socially, a dash was used to create a personal tie between a client and an official rather than a mere contract. A dash at home, according to Price performed the "customary functions of demonstrating respect or deference" (p. 122). A dash in the office however was impersonal according to Price and was perceived as having less potency.

Table 5-8 corroborate Price's results for alternative “c”. 2006 non-literate respondents favored going to the official's house to offer the dash. That said they are much more likely to choose the office dash than their counterparts in 1969. Non-literate respondents were concerned about using an intermediary. They were concerned that the intermediary might ask for a dash or spend the dash intended for the official.

Price cautioned that findings from his study underestimated the role of dash in Ghanaian society because respondents were presented with other options (e.g., seeing a friend or going to the house) that they did not have in real life situations. Chi-square tests for responses in Table 58 show a significant $p$-value $(p<.01)$. This supports the hypothesis that education plays a role in respondents' understanding about their rights as citizens.

To provide further evidence about the presence or lack of service orientation among respondents, they were presented with the following scenario:

Some people say that knowing a "big man" in government plays an important part in whether the government will help a private citizen with some problems he has; other people say that this 
is not so. In your opinion, does knowing a "big man" play an important part in whether the government will help a private citizen?

Table 5-9. Importance of Knowing an Important Man (Percent)

\begin{tabular}{lll}
\hline & $\begin{array}{l}\text { Non- } \\
\text { literate }\end{array}$ & Educated \\
\hline Very Important & 58.7 & 58.2 \\
Somewhat Important & 28.6 & 29.4 \\
Not Very Important & 4.8 & 9.8 \\
Not Important at all & 7.9 & .5 \\
Missing & & \\
Total & - & 2.1 \\
& 100.0 & 100.0 \\
\hline
\end{tabular}

Price did not discuss responses to this question and therefore Table 5-9 presents responses only for 2006 respondents. Table $5-9$ illustrates that a majority of respondents, both literate (58.2\%) and non-literate (58.7\%) believed that knowing an important person was very crucial in getting things done. Responses to this question challenge the assertion that access to modernizing influences is likely to make educated respondents more knowledgeable of their rights and therefore more likely to exercise them. Once again it is common knowledge that networking has rewards. The question does not ask them if they personally know any "big men". Respondents are merely stating the fact that knowing a "big man" grants access. This helps the reader understand why respondents employ "dashing" as one of the available options to receive services. 


\section{Corruption in Ghana}

Price argued that bureaucratic corruption differed from the forms of particularism discussed so far. He defined particularism as "instances when formal rules are violated because of a direct or indirect social tie between a public bureaucrat and some individual or group" (1975, p. 148). Corruption is defined by Price as the situation "when universalistic standards are violated because of considerations of monetary gain on the part of the civil servant" $(1975, \mathrm{p}$. 148). Price added that the socio-cultural system of Ghana created a receptive environment for corruption. This is because expectations placed on public servants by their significant others are so high that the former is unable to meet those needs. The public servant is consequently forced to supplement the meager income through corrupt means. Price argued that this phenomenon is partly a result of the colonial legacy. The Europeans occupying positions in the civil service held prestigious positions and were paid handsomely. With the onset of Africanization, Ghanaians took over positions once held by the Europeans and even though their remuneration was lower than the expatriates received, the indigenes that acquired posts in the civil service were obliged to maintain an appearance of a European lifestyle, which also meant that they had greater obligations to their extended families. Price hypothesized that bureaucrats who engaged in corrupt practices in order to satisfy demands from significant others will be socially rewarded. To test this hypothesis, characteristics of two men were described to respondents. They were asked to choose which of the two they thought was a better man.

1. Official One: He has used his official position to "chop" a great deal of money, but he has shown great generosity, coming to the aid of any of his people who are in need.

\footnotetext{
${ }^{3}$ To chop" is a pidgin English term that refers to the act of appropriating public funds for personal use
} 
2. Official Two: He follows all rules and regulations of his office and has not "chopped" money, but as a result, although he would like to show generosity, he constantly refuses to help any of his people who are in need.

The difference between Tables 5-10 and 5-11 is that the former asks respondents about the perceptions of Ghanaians in general with regards to corruption whereas Table 5-11 specifically seeks the respondents view about the subject by asking which official he or she might want as a relative. Price found that a majority (83\%) of literate respondents felt that most Ghanaians would think the corrupt official was the better man. A majority of the non-literate respondents also believed that most Ghanaians will feel that the corrupt official was the better of the two men described. In Table 5-10, 2006 educated respondents (68.7\%) overwhelmingly believed Ghanaians would prefer the "corrupt" official who takes care of his relatives. Non-literate respondents were almost evenly split on this issue.

Table 5-10. Social Esteem and Organizational Corruption: Effect of Education Level of Respondent's Educational Background (Percent)

Literate

1969
83

17

Uncorrupt official seen as better man

Missing

Total $\chi 2(\mathrm{DF}=1, \mathrm{~N}=242)=12.901, \mathrm{p}<.01$
Non-Literate

19692006

\begin{tabular}{lllll} 
Corrupt official seen as better man & 83 & 68.7 & 66.6 & 47.6 \\
$\begin{array}{l}\text { Uncorrupt official seen as better } \\
\text { man }\end{array}$ & 17 & 24.1 & 33.3 & 49.2 \\
Missing & - & 7.2 & - & 3.2 \\
& 100.0 & 100.0 & 100.0 & 100.0 \\
$\begin{array}{l}\text { Total } \\
\chi 2(\mathrm{DF}=1, \mathrm{~N}=242)=12.901, \mathrm{p}<.01\end{array}$ & $(N=18)$ & $(N=195)$ & $(N=383)$ & $(N=63)$ \\
\hline
\end{tabular}

This question was asked to allow the respondents to dissociate themselves from the public and be as truthful as possible however; non-literates did not have the benefit of anonymity. The concern 
that the interviewer might judge them could have pressured non-literates to choose the morally right response. The reason why 2006 respondents generally prefer the uncorrupt official might be because the former is more accepting of universalism and consequently expects less from the relative.

Respondents were then asked to indicate which of the officials in the scenario presented they would prefer as a relative. This question was to determine the respondent's personal values as opposed to what the average Ghanaian might prefer. A larger proportion of non-literate respondents in Price's sample preferred the corrupt official as a relative. Among Price's literate respondents, $19.2 \%$ of the literate respondents preferred to have the corrupt official as the relative. The composition of Price's sample enabled him to conclude that Ghanaians who had had more contact with Westernization were more likely to accept the separation of formal bureaucratic roles from family roles. For instance, non-literate clients who spoke English were less likely to prefer the corrupt official as compared to the non-literate respondents. For the literate group, freshmen were more likely to favor the corrupt official than seniors. Price noted that even respondents that favored the uncorrupt official noted that their preferences were not the norm. Price concluded that the public servant who appropriates public resources to meet the demands of their significant others will receive social approval by family members and the larger community.

In Table 5-11, a majority of both groups of respondents wanted the uncorrupt official as a relative. It appears that the non-literate group was more likely to prefer the corrupt official as a relative than the literate would. This supports Price's hypothesis that education does have an impact of perception. When these responses are compared with those in Table 5-10, it appears that literate respondents, though they perceived the Ghanaian public as having a preference for 
corrupt officials, chose the uncorrupt official as a relative. The non-literate respondents were also more likely to "malign" the general public than they were to point accusing fingers at themselves. Both the literate and non-literate respondents prefer the uncorrupt official as a relative. This response should be taken guardedly as respondents may have given the "right" answer rather than the "truthful" response especially since the question in 5-11 is judgmental. A point of concern is that 2006 literates are four times more likely than 1969 respondents to prefer the corrupt official. I expected the reverse to be true. It is not possible to say that society has degenerated since 1969 based on this one anomaly. It is clear however that it does not support the trends in the findings.

Table 5-11. Respondent's Choice of Public Servant as Relative (Percent)

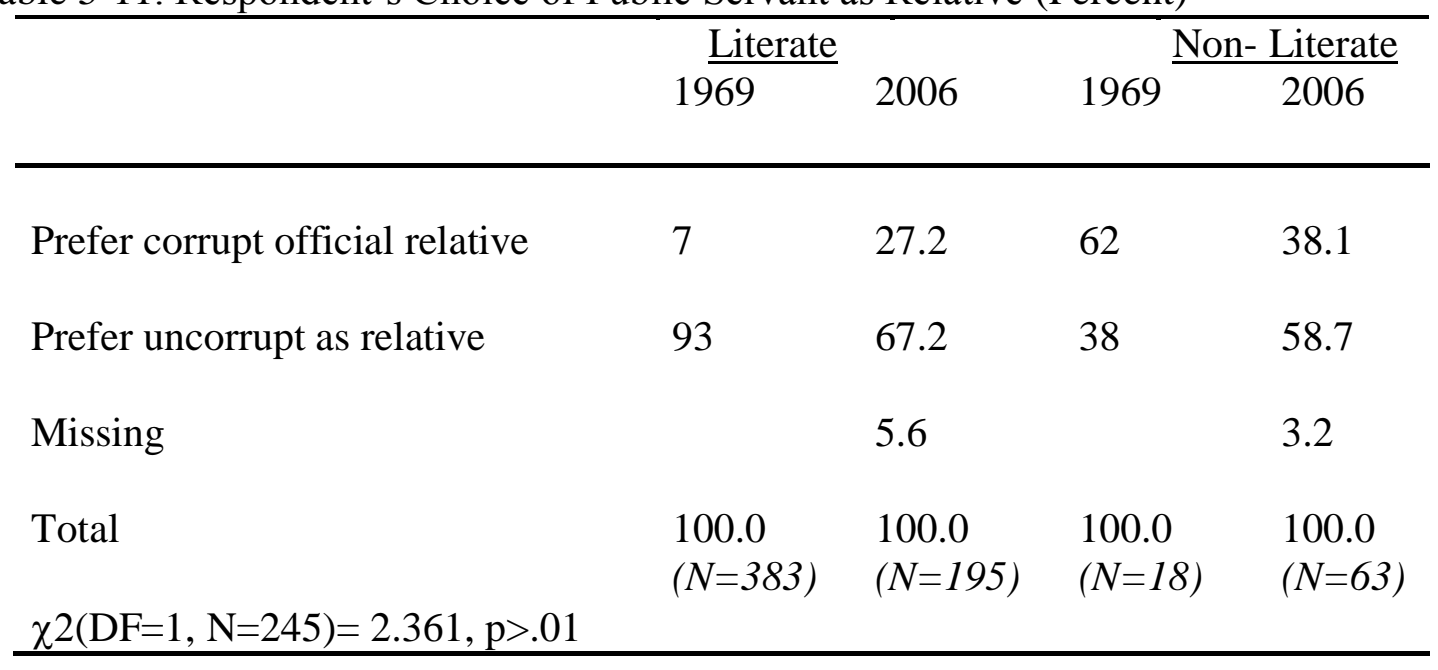

\section{Societal Values Held in High Esteem}

In Table 5-12, respondents were asked to choose among a variety of characteristics, the quality that Ghanaians respected most in an individual; the purpose of asking this questions to determine the type of individual that Ghanaians held in high esteem. One can postulate that the individual that respondents believe is favored by society is likely to be the type of individual that 
respondents (particularly college students) would hope to become.

Price's did not discuss the survey responses to this survey question and as a result, it will not be possible to compare responses. Table 5-13 demonstrates that the three qualities that were popular for the educated clientele group were: an individual who has all the good things in life (29.4\%); one who takes care of his relatives and friends when they are in need $(21.1 \%)$; and one who makes a contribution to the development of Ghana (19.1\%). These three qualities were favored by the non-literate group as well, though not in the same preferential order. An individual who cared for his relations was the most popular $(42.9 \%)$ followed by one who contributed to the development of Ghana (27\%), with an individual possessing material wealth taking the third most favorite position (17.5\%).

Both groups selected similar attributes as the most preferred qualities, albeit with different weightings suggesting they deeply care about these issues. Literate respondents favored an individual with material things and one who took care of his relatives, confirming Price's argument that particularistic expectations from significant others influences patterns of behavior among public servants. College students, who are more likely, than the non-literate in English group, to end up working for the public service gave the least weight to, "one who contributes to the development of Ghana." By extension should they obtain jobs in the public service, their priorities may be to amass wealth rather than work for the development of Ghana. This echoes findings in Chapter 4 where respondents reported a low public service ethic. It also corroborates responses in Table 5-3 where literate respondents indicated that when they graduated, they will be under obligation to support their family members. If college students know that their family is expecting support when they begin to earn a salary, then it is inevitable that they would be primarily concerned with amassing wealth in order to take care of the family, 
hence their support for alternatives "d" and "c".

Table 5-12. Qualities in Individuals that Ghanaians Respect (Percent)

\begin{tabular}{|c|c|c|}
\hline & $\begin{array}{l}\text { Non-literate } \\
\%\end{array}$ & $\begin{array}{l}\text { Literate } \\
\%\end{array}$ \\
\hline a. He/she earns a high salary. & 0 & 14.4 \\
\hline $\begin{array}{l}\text { b. He/she has all the good things in life: a good } \\
\text { car, a big house, fine clothing etc. }\end{array}$ & 17.5 & 29.4 \\
\hline $\begin{array}{l}\text { c. He/she holds a position in which he/she has } \\
\text { many subordinates who must obey orders. }\end{array}$ & 3.2 & 3.1 \\
\hline $\begin{array}{l}\text { d. He/she makes a contribution to the } \\
\text { development of Ghana. }\end{array}$ & 27.0 & 19.1 \\
\hline $\begin{array}{l}\text { e. He/she is able to take care of his/her relatives } \\
\text { and friends should they be in need. }\end{array}$ & 42.9 & 21.1 \\
\hline f. He/she is better at the job than anyone else. & 7.9 & 4.6 \\
\hline $\begin{array}{l}\text { g. He/she is liked by the people with whom } \\
\text { he/she works. }\end{array}$ & 0 & 5.2 \\
\hline $\begin{array}{l}\text { Missing } \\
\text { Total } \\
\chi 2(\mathrm{DF}=6, \mathrm{~N}=250)=25.532, \mathrm{p}<.01\end{array}$ & $\begin{array}{l}1.6 \\
100.0 \\
(N=63)\end{array}$ & $\begin{array}{l}3.1 \\
100.0 \\
(N=195)\end{array}$ \\
\hline
\end{tabular}

The second favorite individual that the non-literate respondents favored was one who wanted to develop Ghana. A possible explanation is that when the statement "He/she makes a contribution 
to the development of Ghana" is translated to the local language, it literally means "an individual who is working hard so Ghana will economically improve". Respondents then could be heard saying they preferred the individual who would help improve the condition of Ghana since that will invariably improve their current economic/social status. It is possible therefore respondents favored individuals whose working attitude led to future benefits for the population at large. In other words, the respondent benefits at a personal level from that public servant's compliant behavior. One must be cautious therefore in concluding that the choice for the individual who works to develop Ghana is a choice for universalism.

\section{Evaluating the Public Service}

Respondents were asked to rate the public service on a five point scale: "very high, high, average, low, and very low". A majority of both literate and non-literate respondents gave the institution's performance an average rating. Other popular ratings were "low" and "very low". This demonstrates that on the whole, respondents do not believe the public service is an effective institution. Responses in Table 5-13 are not surprising since previous discussions prepare the reader for a negative impression of the Ghana public service. Respondents understand however, that the nation cannot do away with the public service meaning they have not given up completely on the Ghanaian administrative state (See Table 14).

Finally, respondents were asked about the future of the public service. They were to agree or disagree with the statements: "If I had my way, I will have little to do with public servants as much as possible" and "I think we should do away with the public service". This was to permit respondents to substantively evaluate the utility of the public service. It is relatively easy to assign letter grades to public agency however respondents were encouraged to think about the functions of the public service and to determine if it should be eliminated. 
Table 5-13. Respondent's Rating of Performance of Public Service (Percent)

\begin{tabular}{lll}
\hline & Non-literate & Literate \\
\hline Very High & 6.3 & 1.5 \\
High & 11.1 & 6.2 \\
Average & 50.8 & 60.3 \\
Low & 14.3 & 26.8 \\
Very Low & 17.5 & 4.6 \\
Missing & 0 & 0.5 \\
Total & & 100.0 \\
$\chi 2(\mathrm{DF}=4, \mathrm{~N}=256=19.464, \mathrm{p}<.01$ & 100.0 & $(N=195)$ \\
\hline
\end{tabular}

Non-literate respondents are more likely to disagree with the statement that "If I had my way, I

will have little to do with the public service". Educated respondents are evenly split on this issue.

Table 5-14. Respondents' Perception about the Role of the Public Service/ Servants (Percent)

\begin{tabular}{|c|c|c|c|c|c|c|c|c|c|c|}
\hline & $\begin{array}{l}\text { Strongly } \\
\text { Agree } \\
5 \\
\text { Non } \\
\text { Literate }\end{array}$ & Literate & $\begin{array}{l}\text { Agree } \\
4 \\
\text { Non } \\
\text { Literate }\end{array}$ & Literate & $\begin{array}{l}\text { Neutral } \\
3 \\
\text { Non } \\
\text { Literate }\end{array}$ & Literate & $\begin{array}{l}\text { Disagree } \\
2 \\
\text { Non } \\
\text { Literate }\end{array}$ & Literate & $\begin{array}{l}\text { Strongly } \\
\text { Disagree } \\
1 \\
\text { Non } \\
\text { Literate }\end{array}$ & Literate \\
\hline $\begin{array}{l}\text { Prefer to } \\
\text { have little to } \\
\text { do with } \\
\text { public } \\
\text { servants }\end{array}$ & 25.4 & 13.3 & 7.9 & 25.1 & 3.2 & 22.6 & 23.8 & 28.2 & 39.7 & 9.2 \\
\hline $\begin{array}{l}\text { We should } \\
\text { do away } \\
\text { with the } \\
\text { public } \\
\text { service }\end{array}$ & 4.8 & 3.6 & 3.2 & 4.1 & 4.8 & 10.8 & 25.4 & 40.5 & 61.9 & 40.5 \\
\hline
\end{tabular}

Perhaps college respondents, who may acquire well-paying jobs after graduation, would be in a 
better position to pay for private services. Non-literates on the other hand, realizing their deficiency may not be able to fathom surviving without the help of government. A majority of respondents disagree with the statement that "we should do away with the public service". It appears that even though respondents do not have a positive impression of public servants they still believe the institution is pertinent for the survival of the nation.

\section{Conclusion}

This chapter examined respondents' perception of the official and familial roles of the public servant. It also examined the extent to which respondents had a service orientation. To a large extent, Price's conclusions were verified by this study however it appeared as if respondents in 2006 were more likely to lean toward universalism as compared to their counterparts in 1969. The study also demonstrated that literate respondents in 2006 were more open to universalism than non-literates except for a few instances when responses from the latter challenged this hypothesis. 


\section{Chapter 6: Concluding Discussion}

This study was interested in answering five concerns 1) whether the variations in motivations that Brehm and Gates identified among American federal bureaucrats were present among Ghanaian bureaucrats; 2) if public service motivation had taken root among public servants in Ghana; 3) the extent to which expectations of significant others mirrored responses in Price's study; 4) if the level of education had any impact on the perception of clients of the public service; 5) to what extent perceptions about the role of the civil service had changed since the late 1960's.

\section{Similarity of Ghanaian Public Servants to their American Counterparts}

Brehm and Gates (1998) said that while supervision had some influence on the work performance of bureaucrats it was not as pervasive as previous scholars had argued. Rather, peers and professional training are better explanations of work performance. Comparison of responses from American and Ghanaian bureaucrats demonstrated that bureaucrats in Ghana generally perceive supervision as having a great impact on their performance. Both also identified pecuniary, functional and solidary preferences as important determinants of work performance. In the case of Ghana, a majority of respondents were satisfied with their chances of getting a promotion and indicated that fringe benefits and salary were important to them, suggesting pecuniary motives reign supreme among Ghanaian bureaucrats. Still respondents also overwhelmingly agreed that they "enjoy[ed] doing my work for the personal satisfaction it gives to me", they also suggested, "It is important that I get the chance to accomplish something worthwhile"; "while in general I like working in this department" indicating that functional preferences was a motivation in bureaucratic behavior. In response to questions geared at solidary preferences, a majority of respondents felt they would gain respect from the colleagues 
when they worked hard and a majority were satisfied with the level of respect they currently enjoyed with their colleagues. Of the three motivators, solidary preferences appear to be the weakest among Ghanaian bureaucrats. Public servants did not appear to mingle with colleagues outside work hours and did not believe their colleagues were a reason why they came to work. Few respondents also took their lunch with their colleagues. Finally, Ghanaian bureaucrats indicated that they worked very hard on their jobs. They also believed that their colleagues worked hard on their jobs as well. This self- appraisal was not supported by clientele respondents, who gave a poor rating to the public service and did not believe that public servants were dedicated to the development of the country.

The fact that the clientele respondents did not believe public servants were performing their tasks efficiently might lead one to reassess the self-appraisal offered by bureaucrats. If respondents have such a low opinion of the public service, it is a cry for government to review the terms of bureaucratic practice. Supervision appeared to have a significant impact on the work performance of Ghanaian bureaucrats and as a result should be exploited by executives in order to direct the behavior of bureaucrats. Incentives should be created to encourage supervisors to get their subordinates to perform the tasks assigned to them. It might be easier to target managers than it might be to attempt to transform all bureaucrats.

\section{Public Service Motivation}

A variety of questions were presented to public servants to determine if public service motivation played an important role in work performance of bureaucrats. In most cases, public servants did not choose alternatives that indicated that they possessed a public service ethic. A majority of respondents said they preferred government work because of the security it provided and most also found security as one of the attractive qualities of the public service. A majority of respondents indicated they would leave the public service for a job with a higher 
salary in a private organization and a majority was also reluctant to advise an intelligent young man to consider a career in the public service. In as much as results do not indicate the presence of a public service ethic among public servants, findings here support previous research (Rainey, 1982; Wittmer, 1991; Massey \& Brown, 1998; Gabris and Simo, 1995; Houston, 2005) that one major reason why individuals choose government work has got to do with the security it provides.

If public service motivation, as well as the desire for security, co-existed among Ghanaian bureaucrats, then society would still benefit because the Ghanaian bureaucracy would be filled with a majority of officials who are interested in serving the public. Results in Chapter 4 (Table 4-12) however demonstrated that public servants were prepared to leave the public sector for a private industry that paid a larger salary. This implies that a majority of public servants are not interested in that job and are there because of the lack of alternatives. This is evident in clientele's perception of public servants. The former do not believe that the latter are interested in public service coupled with the fact that Ghanaians have accepted that to receive service from the public bureaucracy, one has to bribe one's way through. The problem is compounded when one takes into consideration that Ghana is a developing country with a struggling economy. Bureaucrats lack the basic facilities to work with and the use of technology in the public sector is still limited. For instance only hard copies are kept of employee records and it makes it difficult to access information easily. It was impossible for the researcher to gather information about the gender composition, education levels and other demographics about the Ghana public service because it would take too long for those in charge to provide this information for the researcher's use. One then finds the scenario where you have employees who are not entirely interested in that position, are staying there because there is a lack of alternatives and are forced to work with 
very few resources. Considering the expectations that the extended family has of the public servant, the latter is forced to find other sources to supplement the meager salary i.e. resort to demanding bribes. An employee with a high functional motive or high PSM may be able to put the needs of the clientele first in spite of these limitations however data collected from this survey shows a dearth of employees with high PSM in the Ghanaian bureaucracy.

Price encountered the issue of corruption four decades ago and the problem persists now, that is if it has not worsened. An obvious solution would be to raise salary levels to a point where workers would be able to survive without having to demand bribes. The fact that Ghana has a weak economy however means that the government would not be able to implement that policy. Further, it would be naïve to assume that this problem can be eliminated in the near future without any significant changes in the perceptions and expectations of Ghanaian citizens. Ghanaians must understand that as citizens they have the right to receive services from public bureaucracies without bribing them. Ghanaians must also reduce their expectations of family members in public (and private organizations), allowing the bureaucrat to worry less about having a standard of living that breaks his budget. Changing perceptions and expectations however would not be easy to do. The government however on multiple occasions has employed radio and television to educate the public when policies are lacking in public support. I hypothesized that Ghanaians in 2006 would be more understanding of universalism on the part of the bureaucrat. Though this hypothesis was confirmed, a majority of the respondents expect the bureaucrat to be particularistic. The moderation in expectations after four decades implies that time may help Ghanaians lower expectations more. However in the meantime public education might be the way to go. In addition to the three options discussed so far such as increasing salaries, reducing expectations and changing perceptions, another solution would be to review 
the hiring process in the public sector to ensure that the right candidate is hired for the job. Reducing the chances of adverse selection may help reduce the problem of agency.

\section{Comparing Responses of Public Servants to Clients}

One of Price's theses is that the nature of Ghanaian society inhibits the bureaucratic institution from functioning effectively and similarly to its counterparts in the Western world. This is because Ghanaian society only allowed for the bureaucracy to be institutionalized in status, not in role. Ghanaian society is communitarian and therefore it behooves on every member to comport him or herself in line with the dictates of the expectations of the larger group. In order to illuminate this characteristic of Ghanaian society, some questions were asked of public servants and of the clientele population about the expectations of significant others. It was expected that if bureaucrats were aware of these expectations, they would model their behavior to fit these expectations.

\section{Comparing the non-literate and Literate Clientele}

Responses of literates and non-literate respondents were compared to examine their perception of the official and familial roles of the public servant. To a large extent, Price's conclusions were verified by this study however it appeared as if respondents in 2006 were more likely to lean toward universalism as compared to their counterparts in 1969 . The study also demonstrated that literate respondents in 2006 were more open to universalism than non-literate respondents and were more likely to have a service orientation.

Improvements in Education

K-12 education in Ghana has been free since the introduction of Free Compulsory and Universal Basic Education (FCUBE) by the Rawlings' government in 1992. The number of tertiary institutions has tripled since the 1960's making it easier for more Ghanaians to go to college. These are some of the changes that have taken place since Price's study in the education 
sector and may contribute to the changes in expectations. Greater access to education in general and higher education in particular is expected to make Ghanaians even more accepting of universalistic behavior. Education, particularly higher education would make citizens aware of their rights and hence more likely to demand them. Future improvements in the education sector should therefore result in greater changes in perceptions and expectations of the $21^{\text {st }}$ century Ghanaian.

\section{The Professional Ghanaian Civil Service}

A professional Ghanaian civil service would compose of conscientious bureaucrats who follow the rules of bureaucratic behavior and standard operating procedures. The professional bureaucrat would acknowledge that it is his duty to provide the client a service and not a favor he is granting to the latter. The professional Ghanaian civil service may not necessarily resemble its Western counterpart but would function effectively in the communitarian Ghanaian society. The occasional favor to a family member i.e. allowing a family member to jump the queue, granting a qualified relative an interview or a job etc would not be as frowned upon if everyone has a chance of receiving quality service. Society, not just family members, would not understand why a relation in a privileged position did not help the other relative who was in need. Being communitarian means being concerned about the welfare of the extended family. In a society where a welfare state is nonexistent, a strong and vibrant family system keeps society functioning. They key is for the bureaucracy to provide the services for which they were established. For instance, a couple of years ago, the passport office took at least three months to process a passport just because officials were waiting to be offered bribes. There was no guarantee that a request would be processed after the application was submitted. Today, it only takes about two weeks to process a passport. The applicant need not know "a big man" and need not bribe anyone. Knowing that it is simpler to apply for a passport, individuals may not even 
bother their family members who are in the organization to facilitate the process. This change in the functioning of the passport office can be credited to the management's response to public outcry. The professional Ghana civil service would therefore be filled with managers with public service motivation, and an attractive benefits package to keep them motivated. The institution would also be equipped with modern technology to make working easier for all employees. The civil service training school would have its curriculum revamped. Courses in customer service skills, management skills, teamwork etc would be taught. The current civil service week celebration would be continued to raise awareness about the roles of the institution and also as a means to evaluate the effectiveness of the institution. A professional Ghanaian civil service would fulfill the roles stipulated in the Ghanaian Constitution and would once more be an institution where the graduates would want to work even when other alternative are available.

\section{Future Research}

The next step in this process of comprehending motivations of Ghanaian bureaucrats is to compare employees of two different institutions (private and public) in the same social environment to determine if a change in type of institution will affect the behavior of employees. Ghana does not employ the hourly wage system where employees are paid based on their output and performance. All employees are salaried and most salaries are low for which reason most employees who have the opportunity to do so have second and third jobs. An individual may work both in the private sector and public sector, yet it is believed that the same employee is more effective in the private sector. For instance, Ghanaians consider the private universities to be more effective and worth the cost even though the professors that teach in the public universities constitute a majority of instructors in the private sector and students pay ten times more in private institutions than they would pay in the public university. Clearly, in private institutions, managers/owners keep a stricter eye on their employees since non-performance costs 
the company and hence the profit margin. The private sector is best able to catch slacking on the part of employees. That is not to say the private sector has no slackers and the public service is filled with inefficient workers.

Public Service Motivation scholars (PSM) have examined attitude to public service work among employees of the public sector, private sector and non-profit sector in the United States. Some posit that there is no change in attitude toward job security among employees of the various sectors (Rainey, 1982; Wittmer 1991). Yet others argue that employees of the non- profit sector are more likely to have a public service attitude than those in the other sectors (Gabris and Simo, 1995). Another group maintains that public sector employees are more likely to have PSM (Brewer, Selden \& Facer II, 2000; Perry and Wise, 1990). A follow-up study could examine if variations in motivation exist among employees of different sectors in Ghana. Issues to be examined are whether type of institution affect attitude to work? Is supervision the confounding variable? Or is it monetary rewards? Do employees truly work harder in private institutions in Ghana in particular? If these employees are put in the public sector, is their productivity going to diminish? Do employees in the private sector feel the pressure to be particularistic? Are these employees better able to prevail against the pressure to offer preferential treatment? Do private organizations have the two behavioral requirements of organizational effectiveness i.e. “dependable role performance" and "spontaneous behavior”?

Qualitative research on public servants in Ghana is scarce- particularly research that replicates studies done in the past. This study therefore enables us understand the factors motivating the public servant. The study demonstrates that official behavior is still very much a product of perceived expectations of significant others. Clientele respondents appeared to have moderated their expectations of public servants who are family members and this is particularly 
so when clients have access to education. One can therefore surmise that in a few years, all things being equal (improvements in education, access to other forms of modernization etc.) significant others should be more understanding of the official expectations of the public servant and may be more willing to let the bureaucrat follow the rules of bureaucratic practice. When that happens, it will be possible to argue that the bureaucracy in Ghana has been institutionalized not just in status but in role as well. This does not mean that the Ghanaian bureaucracy would resemble its Western counterparts but rather that public servants would work according to their standard operating procedures and would become effective agents of the principals that depend on them. 


\section{References}

Adedeji, John L. 2001. "The Legacy of J.J. Rawlings in Ghanaian Politics". African Studies Quarterly 5(2): 1. [online] URL: http://web.africa.ufl.edu/asq/v5/v5i2a1.htm.

Alonso, Pablo, and Gregory Lewis. 2001. "Public Service Motivation and Job Performance: Evidence From the Federal Sector. American Review of Public Administration, 31(4): 364-380.

Apter, David. Ghana in Transition. 1972. Princeton New Jersey.

Arrow, Kenneth. (1985). "The Economics of Agency." in J. Pratt and R. Zeckhauser, eds., Principals and agents: The Structure of Business, Boston: Harvard University Press. Pp 37-51.

Austin, Dennis. 1985. “Ghana: Less than a Revolution”. Conflict Studies. 181: 1-21

1976. Ghana Observed: Essays on the politics of a West African republic. Manchester University Press.

1970. Politics in Ghana: 1946-1960. Oxford University Press: London, Oxford and

New York.

Ayee, Joseph. 2002. "The 2000 General Elections and Presidential Run-off in Ghana: An Overview". Democratization. Vol.9:.2. pp 148-174.

Ayoade, John. 1988. "States Without Citizens: An Emerging African Phenomenon" in The Precarious Balance: State and Society in Africa, edited by Donald Rothchild and Naomi Chazan. Westview Press: Boulder and London.

Azarya, Victor. 1988. "Reordering State-Society Relations: Incorporation and Disengagement" in The Precarious Balance: State and Society in Africa, edited by Donald Rothchild and Naomi Chazan. Westview Press: Boulder and London.

Banks, Jeffrey, and Barry R. Weingast. 1992. "The Political Control of Bureaucracies under Asymmetric Information.” American Journal of Political Science 36:509-24.

Baldwin, Norman. 1987. "Public vs Private: Not That Different, Not That Consequential." Public Personnel Management 16:181-93.

Barnard, Chester. 1938. The Functions of the Executive. Cambridge, MA: Harvard University Press.

Bellante, Don and Albert Link. 1981. "Are Public Sector Workers More Risk Aversive than Private Sector Workers?” Industrial and Labor Relations Review, 34:408-12.

Blank, Rebecca. (1985). "An Analysis of Workers' Choice Between Employment in the Public and Private Sectors.” Industrial and Labor Relations Review, 38: 11-19. 
Blair, William, and James Garand. 1995. "Are Bureaucrats Different? Democratic Values, Political Tolerance, and Support for the Political system Among Government Employees and Other Citizens 1982-1992. Paper presented at the annual Meeting of the American Political Science Association, Chicago, Il, August 1-September 3.

Boateng E. A. 1996. Government and the People: Outlook for Democracy in Ghana. Institute for Economic Affairs: Ghana.

Brewer, Gene. 2003. "Building Social Capital: Civic Attitudes and behavior of Public Servants." Journal of Public Administration Research and Theory 13:5-26.

Brewer, Gene, Sally Selden and Rex Facer II. 2000. "Individual Conceptions of Public Service Motivation." Public Administration Review, 60(3): 255-264.

Brehm, John, and Scott Gates. 1997. Working, Shirking, and Sabotage. Ann Arbor: University of Michigan Press.

Buchanan, Bruce II. 1975. "Red Tape and the Service Ethic.” Administration and Society 6(4):424-44.

Callaghy, Thomas. 1988. "The State and the Development of Capitalism in Africa: Theoretical, Historical, and Comparative Reflections" in The Precarious Balance: State and Society in Africa, edited by Donald Rothchild and Naomi Chazan. Westview Press: Boulder and London.

Chazan, Naomi. 1988. "State and Society in Africa: Images and Challenges" in The Precarious Balance: State and Society in Africa, edited by Donald Rothchild and Naomi Chazan. Westview Press: Boulder and London.

Chazan, Naomi. 1989. "Planning Democracy in Africa: A Comparative Perspective on Nigeria and Ghana." Policy Sciences 22: 325 -357.

(1983) An Anatomy of Ghanaian Politics: Managing Political Recession, 1969-1982.

Westview Press: Boulder, Colorado.

Conway, Margaret. 2000. Political Participation in the United States. Washington, DC: Congressional Quarterly Press.

Crewson, Philip. 1997. "Public Service Motivation: Building Empirical Evidence.” Journal of Public Administration Research and Theory. 7(4): 499-518.

Dzorgbo, Dan-Bright. 1998. Ghana in Search of Development: The Challenge of Governance, Economic Management and Institution Building. Reprocentralen HSC-Sweden.

Gabris, Gerald, and Gloria Simo. 1995. "Public Sector Motivation as an Independent Variable Affecting Career Decisions". Public Personnel Management 21(1): 34-51.

Galambos, Louis. 1987. The New American State. Baltimore: Johns Hopkins University Press. 
Goldberg, Victor. P. 1976. “ Regulation and Administered Contracts.” Bell Journal of Economics 7(2): 426-41.

Golden, Marissa Martino. 2000. What Motivates Bureaucrats? NY: Columbia University Press.

Hedge, David and Renee Johnson. 2002. "The Plot That Failed." Journal of Public Administration Research and Theory. 12(Jul)3:334-351.

Gordon, Raymond G., Jr. (ed.), [map] 2005. Ethnologue: Languages of the World, Fifteenth edition. Dallas, Tex.: SIL International. Online version: http://www.ethnologue.com/ (18 June 2008).

Houston David 2005. "Walking the Walk of Public Service Motivation: Public Employees and Charitable Gifts of Time, Blood and Money." Journal of Public Administration Research and Theory 16:67-86.

Huber, John D. and Shipan Charles R. Deliberate Discretion? The Institutional Foundations of Bureaucratic Autonomy.

Issachar Joseph. “Address Delivered on the Occasion of the $7^{\text {th }}$ Quadrennial Delegates Conference of the Greater Accra Regional branch of the civil Servants Association" at the Auditorium of the Civil Servants Association on $29^{\text {th }}$ June, 2006.

Issachar, Joseph. "Problems and Challenges Facing the Civil Service in Service delivery to the Public". Presentation during Civil Service Week: June $19^{\text {th }} 2006$.

Jacson, Robert H and Carl Rosberg. 1982. Personal Rule in Black Africa: Prince, Autocrat, Prophet, Tyrant. University of California Press.

Jones, Bryan D. 2001. Politics and the Architecture of Choice. Chicago: The University of Chicago Press.

Jurkiewicz, Carole; Massey, Tom; and Brown, Roger 1998. "Motivation in Public and Private Organizations.” Public Productivity and Management Review 21:230-50.

Kilpatrick, Franklin., Cummings, Milton and Jennings, Kent. 1964. The Image of the Federal Service. Washington, DC: Brookings.

Kingdon J., 1984, Agendas, alternatives and public policies, New York: Harper-Collins.

Lewis, David E. 2003. Presidents and the Politics of Agency Design. Stanford: Stanford University Press.

MacGaffey, Janet. 1988. "Economic Disengagement and Class Formation in Zaire" in The Precarious Balance: State and Society in Africa, edited by Donald Rothchild and Naomi Chazan. Westview Press: Boulder and London. 
Mann Gregory. 2006. “A Motive to Serve: Public Service Motivation in Human Resource Management and the Role of PSM in the Nonprofit Sector. Public Personnel Management. 35(1): 34-48.

Mitnick, Barry. 1984. “The Bureaucrat as Agent.” paper presented at the APSA Annual Meeting.

Moe, Terry. 1984. "The New Economics of Organization." AJPS. 28(Nov):739-77. JSTOR

Morone, James A. 1998. The Democratic Wish. New Haven: Yale University Press.

Moynihan Donald and Sanjay Pandey. 2007. The Role of Organizations in Fostering Public Service Motivation. Public Administration Review.

Naff, K. C. and Crum J. 1998. "Working for America: Does Public Service Motivation Make a Difference?" Review of Public Personnel Administration, 19(4):5-16.

Newstrom, John; Reif, William and Monckza, Robert. 1976. "Motivating the Public Employee: Fact vs. Fiction." Public Personnel Management 5:67-72.

Ninsin, Keame. "Three Levels of State Reordering: The Structural Aspects" in The Precarious Balance: State and Society in Africa, edited by Donald Rothchild and Naomi Chazan. Westview Press/ Boulder and London.

Ninsin, Keame. 1988. "Three Levels of State Reordering: The Structural Aspects" in The Precarious Balance: State and Society in Africa, edited by Donald Rothchild and Naomi Chazan. Westview Press: Boulder and London.

Niskanen, William. 1975. "Bureaucrats and Politicians." Journal of Law and Economics 18(3): 645-59

Nugent, Paul. 1995: Big Men Small Boys and Politics in Ghana. Accra: Asempa Publishers.

Ocquaye, Mike. 2004. Politics in Ghana 1982-1992: Rawlings, Revolution and Populist Democracy. Thomson Press: New Dehli.

Parpart, Jane. 1988. "Women and the state in Africa" in The Precarious Balance: State and Society in Africa, edited by Donald Rothchild and Naomi Chazan. Westview Press: Boulder and London.

Parsons, Talcott, and Edward Shils, eds. 1951. Toward A General Theory Of Action. New York: Harper \& Row, 1951.

Perry James L. 1997. “Antecedents of Public Service Motivation. Journal of Public Administration Research and Theory." 7(2):181-97.

Perry James L. 1996. Measuring Public Service Motivation: An Assessment of Construct Reliability and Validity. Journal of Public Administration Research and Theory 6(1): 5-22.

Perry James and Wise Lois Recascino (1990) "The Motivational Bases of Public Service" Public Administration Review 50(3): 367-73. 
Price, Richard M. 1975 Society and Bureaucracy in Contemporary Ghana. Berkeley: University of California Press.

Rainey, Hal G. 1982. "Reward Preferences among Public and Private Managers: In Search of the Service Ethic." American Review of Public Administration 16(4): 288-302.

Ravenhill John. 1988. "Redrawing the Map of Africa?" in The Precarious Balance: State and Society in Africa, edited by Donald Rothchild and Naomi Chazan. Westview Press: Boulder and London.

Ress, R. (1985). The theory of principal and agent. Bulletin of Economic Research,Vol. 37,No.1.

Riker, William H. 1962. The Theory of Political Coalitions. New Haven, CT: Yale University Press.

Rose, Richard. 1993. Lesson-Drawing in Public Policy: A Guide to Learning Across Time and Space. (Chatham NJ: Chatham House, 1993).

Ross, Steven. 1973. "The economic theory of agency: The principal's problem." American Economic Review, 63(2): 135-139.

Rothchild Donald and Michael Foley. 1988. "African States and the Politics of Inclusive Coalitions" in The Precarious Balance: State and Society in Africa, edited by Donald Rothchild and Naomi Chazan. Westview Press: Boulder and London.

Sartori, Giovanni. 1970. “Concept Misinformation and Comparative Politics.” American Political Science Review 64 (4): 1034-1041

Scott, Patrick and Sanjay Pandey. 2005. "Red Tape and Public Service Motivation: Findings from a National Survey of Managers in State Health and Human Service Agencies." Review of Public Personnel Administration, 25(2): 155-180.

Schuster, Jay. 1974. "Management Compensation Policy and the Public Interest." Public Personnel Management 3:510-23.

Skowronek, Stephen (1982). Building a New American State: The Expansion of National Administrative Capacities, 1877-1920. Cambridge: Cambridge University Press.

Selltiz, C., Wrightsman, L. S. \& Cook, S. W. (1976) Research Methods in Social Relations, 3/e, Holt, Reinhart \& Winston, New York.

White, William D. (1992). Information and the control of agents. Journal of Economic Behavior and Organization, Vol. 18: 111-117.

Wilson, James Q. 1989. Bureaucracy. NY: Basic Books. 
Wittmer, Dennis. 1991. "Serving the People or Serving for Pay: Reward Preferences Among Government, Hybrid Sector, and Business Managers." Public Productivity and Management Review 14:369-83.

Wood, Dan, B., and Richard Waterman. 1995. Bureaucratic Dynamics: The Role of Bureaucracy In a Democracy. Boulder, CO: Westview Press.

Young Crawfurd. 1988. "The African Colonial State and Its Political Legacy" in The Precarious Balance: State and Society in Africa, edited by Donald Rothchild and Naomi Chazan. Westview Press: Boulder and London.

Main Report of the Commission on the Structure and Procedures of the Ghana Civil Service (19751976). Volume 1.

www.ghanagov.org 
Appendix

\section{Important Dates in Ghanaian Political History}

February $1951 \quad$ Convention People's Party (CPP) wins first national election under Kwame Nkrumah

$6^{\text {th }}$ March $1957 \quad$ Ghana attains independence

1957-1966-

The CPP civilian government is in power with Dr. Kwame Nkrumah as first Prime Minister and later first president.

$24^{\text {th }}$ Feb $1966 \quad$ Colonel Kotoka overthrows Nkrumah's CPP regime in a coup while Nkrumah is on a peace mission to Hanoi. Kotoka himself is killed in military action.

1966-1969- $\quad$ Military regime of the National Liberation Council (NLC) headed by Lt. General Ankrah and later by Lt. General Afrifa.

1969-1972: $\quad$ The Progress Party (PP) civilian government is in power with Professor Busia as Prime Minister.

1972-1979: $\quad$ The military regime of National Redemption Council and later the Supreme Military Council (NRC/SMC) led by General Acheampong and later by General FWK Akuffo.

14-15 May 1979 Failed coup attempt by Flt-Lt Jerry John Rawlings

June 1979:

The Armed Forces Revolutionary Council (AFRC) military regime led by Flt. Lt. J.J. Rawlings comes to power in a mutiny. Senior military officers are executed including Acheampong and Akuffo.

September 1979 Rawlings hands power to elected civilian government of People's National Party.

1979-1981: $\quad$ The Peoples National party (PNP) civilian government of Dr. Hilla Limann as Executive President.

31 Dec 1981-1990: The military regime of the Provisional National Defense Council led by Flt. Lt. J.J. Rawlings launches revolution.

28/29 October 1982 Failed plot on PNDC by left-wingers

23 November 1982 Attempted coup, followed by purges and resignations in administration

19 June 1983

Nearly successful coup attempt

September 1989

August 1991

Arrest of Major Courage Quarshigah and others in connection with alleged coup plot

Consultative Assembly sits to decide on a new constitution

3 November 1992

7 January 1993

Presidential elections won by Jerry Rawlings

Inauguration of the Fourth Republic

3 November 1996

Presidential elections won for the second time by Jerry Rawlings

3 November 2000

Presidential elections won by the opposition -New Patriotic Party led by John Agyekum Kuffour

3 November 2004 President Kuffour wins a second term for the NPP

**Source: Ocquaye 2004 and Nugent 1995 


\section{Ethologic Map of Ghana}

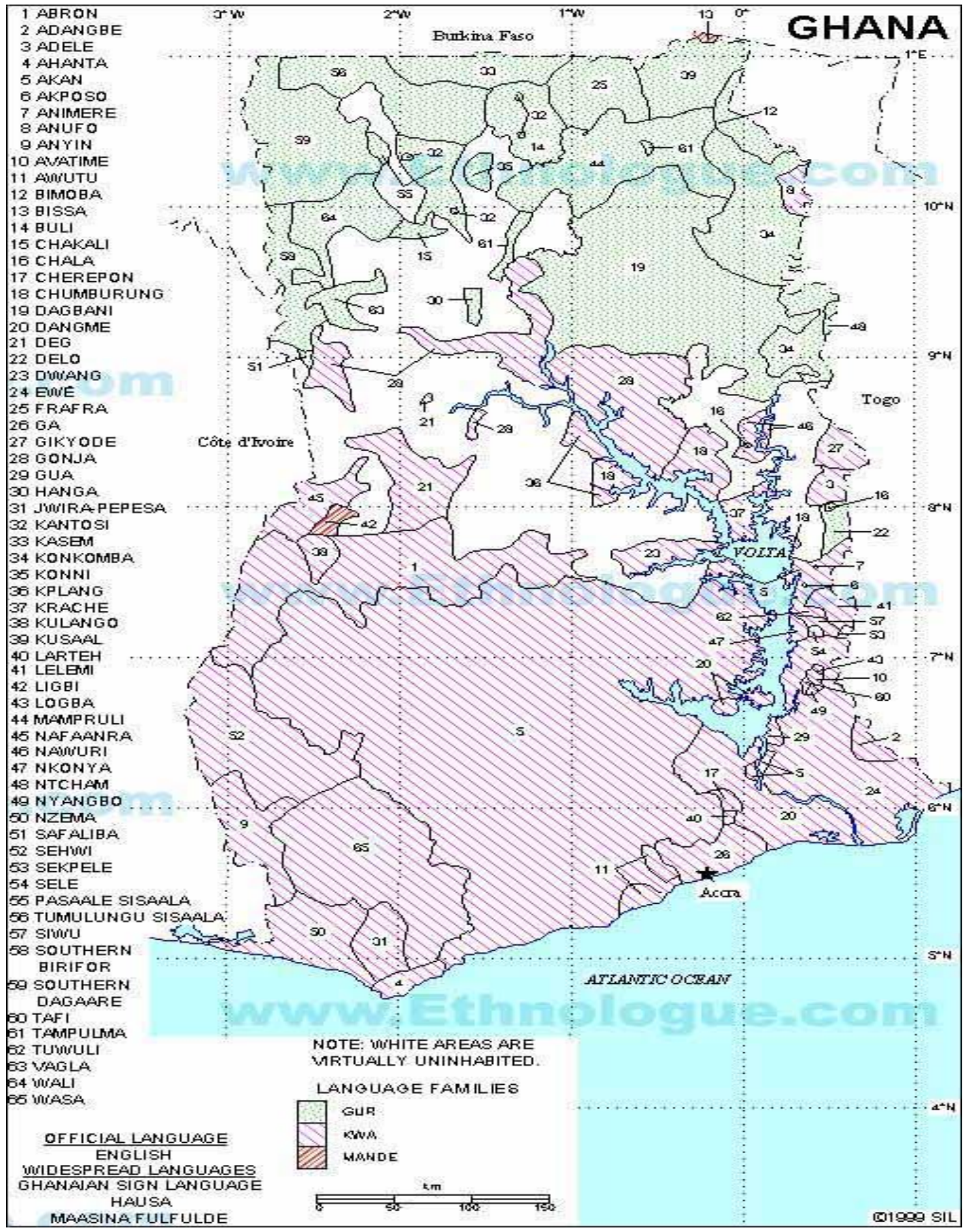

“ETHNOLOGIC MAP OF GHANA”. SIL INTERNATIONAL (GORDON, 2005). 
Dear Respondent,

I am a doctoral student in West Virginia University, Morgantown in the United States. The questionnaire attached is a survey about opinions of public servants and the factors affecting them as they fulfill their responsibilities. This study is part of a dissertation project to fulfill the requirements of a doctoral degree at West Virginia University.

The answers you give will in no way be identified with you personally. No names or identifiers will be on the survey or in the database and so the information you give will be strictly confidential. The questions asked are based on opinions not facts therefore there will be no such things as a right or wrong answer. It is only requested of you that you be as frank as you can in your responses. If you are uncomfortable with a question, you do not have to answer it. Your employment or class grade will not be affected if you choose not to respond to this survey. Participation in the survey is purely voluntary.

Please take a few minutes to answer the following questions. Please write responses in the spaces provided. Where two or more alternates are given, please pick the appropriate answer

If you should have any questions, please fell free to email me at clokko@mix.wvu.edu

Sincerely,

Christine Lokko 
The questionnaire below is a survey about opinions of public servants and the factors affecting them as they fulfill their responsibilities. This study is part of a dissertation project to fulfill the requirements of a doctoral degree at West Virginia University, Morgantown, in the United States.

The answers you give will in no way be identified with you personally. You can remain completely anonymous. The questions asked are based on opinions not facts therefore there will be no such thing as a right or wrong answer. It is only requested of you that you be as frank as you can in your responses. Please take a few minutes to answer the following questions. Please write responses in spaces provided. Where two or more alternates are given, please tick the appropriate answer. If you are currently retired please answer the questions to the best of your ability, with reference to the last position you held.

Q1. Gender :

Q2. Ethnic group:

Q3. Place of Work:

Q4. Number of years in the public service:

Q5. Please tick your work status:

Q5A. Currently working

Q5B. Retired

Q5C. Retired and working

Q6. What is your present rank in the public service?

Q6A: If you are retired what rank did you retire at?:

Q7. Do you report to supervisors?

(1)Yes

(2)No

Q7A. How many supervisors:

Q8. Do subordinates report to you? (1)Yes (2)No Q8A. How many subordinates:

Q9. Do you have additional sources of income: Yes (1) No (0) 
Q10. Please tick highest level of education you have attained:

\begin{tabular}{|rl|l|}
\hline a. & $\begin{array}{l}\text { Senior Secondary } \\
\text { School }\end{array}$ & \\
\hline b. & Polytechnic & \\
\hline c. & Bachelors & \\
\hline d. & Masters & \\
\hline e. & Doctorate & \\
\hline f. & Post Doctorate & \\
\hline g. & $\begin{array}{l}\text { Other, please } \\
\text { specify }\end{array}$ & \\
& & \\
\hline
\end{tabular}

Q11: Please tick your age group:

\begin{tabular}{|l|l|}
\hline a. $20-25$ years & \\
\hline b. $25-30$ years & \\
\hline c. $30-35$ years & \\
\hline d. $35-40$ years & \\
\hline e. $40-45$ years & \\
\hline f. $45-50$ years & \\
\hline g. $50-55$ years & \\
\hline h. $55-60$ years & \\
\hline i. 60 and above & \\
\hline
\end{tabular}

Q12. Place of Education- Please tick all that apply to you.

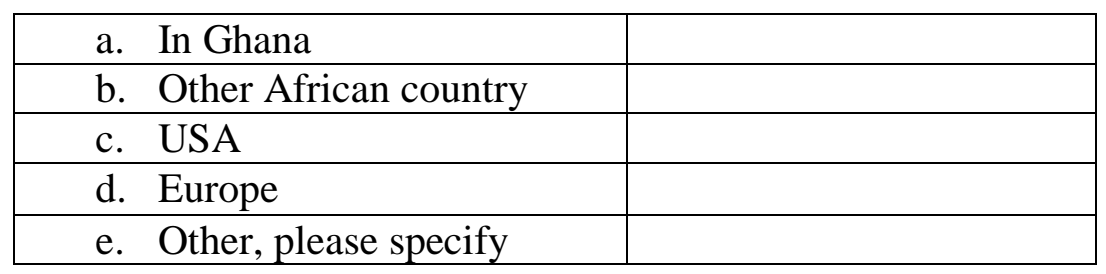

Q13. Some people feel that that their colleagues have an impact on their work performance. Please read the following statements and tick the appropriate corresponding boxes that indicate whether or not you strongly agree, agree, are neutral, disagree, or strongly disagree with the statements below about how colleagues impact your work performance. 


\begin{tabular}{|c|c|c|c|c|c|}
\hline & $\begin{array}{l}\text { Strongly } \\
\text { Agree } \\
5\end{array}$ & $\begin{array}{c}\text { Agree } \\
4\end{array}$ & $\begin{array}{c}\text { Neutral } \\
3\end{array}$ & $\begin{array}{c}\text { Disagree } \\
2 \\
2\end{array}$ & $\begin{array}{l}\text { Strongly } \\
\text { Disagree } \\
1\end{array}$ \\
\hline $\begin{array}{l}\text { a. My job requires that I work closely with } \\
\text { other people }\end{array}$ & & & & & \\
\hline $\begin{array}{l}\text { b. Working hard on my job leads to gaining } \\
\text { respect from coworkers }\end{array}$ & & & & & \\
\hline $\begin{array}{l}\text { c. The people I work with generally do a good } \\
\text { job }\end{array}$ & & & & & \\
\hline $\begin{array}{l}\text { d. I am satisfied with the respect I receive } \\
\text { from the people I work with }\end{array}$ & & & & & \\
\hline $\begin{array}{l}\text { e. I like coming to work because of my } \\
\text { coworkers }\end{array}$ & & & & & \\
\hline $\begin{array}{l}\text { f. I often call upon my colleagues for help on } \\
\text { problems which may arise in the course of } \\
\text { my work }\end{array}$ & & & & & \\
\hline $\begin{array}{l}\text { g. I spend a lot of time with people in my } \\
\text { department outside of working hours }\end{array}$ & & & & & \\
\hline $\begin{array}{l}\text { h. I often take my lunch with other people I } \\
\text { work with }\end{array}$ & & & & & \\
\hline
\end{tabular}

Q14. Several scholars have said that some employees derive personal satisfaction from public service. Please read the following statements and tick the appropriate corresponding boxes that indicate whether or not you strongly agree, agree, are neutral, disagree, or strongly disagree with the statements below.

\begin{tabular}{|c|c|c|c|c|c|}
\hline & $\begin{array}{c}\text { Strongly } \\
\text { Agree } \\
5\end{array}$ & $\begin{array}{c}\text { Agree } \\
4\end{array}$ & $\begin{array}{c}\text { Neutral } \\
3\end{array}$ & $\begin{array}{c}\text { Disagree } \\
2\end{array}$ & $\begin{array}{c}\text { Strongly } \\
\text { Disagree } \\
1\end{array}$ \\
\hline $\begin{array}{l}\text { a. The amount of work expected of me, } \\
\text { job, is just right }\end{array}$ & & & & & \\
\hline b. In general, I like working in this depal & & & & & \\
\hline $\begin{array}{l}\text { c. I enjoy doing my work for the persona } \\
\text { satisfaction it gives me }\end{array}$ & & & & & \\
\hline $\begin{array}{l}\text { d. Working hard on my job leads to gooc } \\
\text { performance }\end{array}$ & & & & & \\
\hline $\begin{array}{l}\text { e. It is important that I get the chance to } \\
\text { accomplish something worthwhile }\end{array}$ & & & & & \\
\hline
\end{tabular}


Q15. Some people are motivated to work hard because of the benefits that come with the job while others are not as motivated by these benefits. Please read the following remarks and tick appropriate corresponding boxes that describe your sentiments about these statements.

\begin{tabular}{|c|c|c|c|c|c|}
\hline & $\begin{array}{c}\text { Strongly } \\
\text { Agree } \\
5\end{array}$ & $\begin{array}{c}\text { Agree } \\
4\end{array}$ & $\begin{array}{c}\text { Neutral } \\
3\end{array}$ & $\begin{array}{c}\text { Disagree } \\
2\end{array}$ & $\begin{array}{c}\text { Strongly } \\
\text { Disagree } \\
1\end{array}$ \\
\hline $\begin{array}{l}\text { a. I am satisfied with my chances for getting a } \\
\text { promotion }\end{array}$ & & & & & \\
\hline $\begin{array}{l}\text { b. The fringe benefits I receive are important } \\
\text { to me }\end{array}$ & & & & & \\
\hline c. The salary I receive is very important to me & & & & & \\
\hline $\begin{array}{l}\text { The presence of the following resources at my } \\
\text { work place is very important to me: }\end{array}$ & & & & & \\
\hline d. Computer & & & & & \\
\hline e. Internet service & & & & & \\
\hline f. Secretary & & & & & \\
\hline
\end{tabular}

Q16. It has been argued that supervision has a stronger impact on some subordinates than others. Please read the following statements and tick the appropriate corresponding boxes that indicate whether or not you strongly agree, agree, are neutral, disagree, or strongly disagree with the statements below.

\begin{tabular}{|c|c|c|c|c|c|}
\hline & $\begin{array}{l}\text { Strongly } \\
\text { Agree } \\
5\end{array}$ & $\begin{array}{c}\text { Agree } \\
4 \\
\end{array}$ & $\begin{array}{c}\text { Neutral } \\
3 \\
\end{array}$ & $\begin{array}{c}\text { Disagree } \\
2 \\
2\end{array}$ & $\begin{array}{l}\text { Strongly } \\
\text { Disagree } \\
1\end{array}$ \\
\hline $\begin{array}{l}\text { a. When an employee continues to do his/her } \\
\text { job poorly, supervisors will take corrective } \\
\text { action }\end{array}$ & & & & & \\
\hline $\begin{array}{l}\text { b. My job performance is carefully evaluated by } \\
\text { my supervisor }\end{array}$ & & & & & \\
\hline $\begin{array}{l}\text { c. My supervisor insists that subordinates work } \\
\text { hard }\end{array}$ & & & & & \\
\hline $\begin{array}{l}\text { d. My supervisor sets clear goals for me in my } \\
\text { present job }\end{array}$ & & & & & \\
\hline $\begin{array}{l}\text { e. I will be demoted or removed from my } \\
\text { position if I perform poorly }\end{array}$ & & & & & \\
\hline $\begin{array}{l}\text { f. Supervisors in my organization consult with } \\
\text { their subordinates on how things should be } \\
\text { done }\end{array}$ & & & & & \\
\hline $\begin{array}{l}\text { g. I feel very free to disagree with my } \\
\text { supervisor to his/her face. }\end{array}$ & & & & & \\
\hline
\end{tabular}


Q17. What is the rank of the immediate superior to whom you report?

How often do you see your immediate supervisor? Please pick ONE response from the alternatives below.
a. At least once a day
b. About every other day
c. At least once a week
d. At least once a month
e. Less than once a month

Q18. Some people feel that public servants do not work hard enough while others believe they do. Please read the following statements and tick the appropriate corresponding boxes that indicate whether or not you strongly agree, agree, are neutral, disagree, or strongly disagree with the statements below.

\begin{tabular}{|c|c|c|c|c|c|}
\hline & $\begin{array}{l}\text { Strongly } \\
\text { Agree } \\
5\end{array}$ & $\begin{array}{c}\text { Agree } \\
4 \\
\end{array}$ & $\begin{array}{c}\text { Neutral } \\
3\end{array}$ & $\begin{array}{c}\text { Disagree } \\
2\end{array}$ & $\begin{array}{c}\text { Strongly } \\
\text { Disagree } \\
1\end{array}$ \\
\hline $\begin{array}{l}\text { a. Most of the people here work hard on } \\
\text { their job }\end{array}$ & & & & & \\
\hline $\begin{array}{l}\text { b. I am not paid enough so I only give } \\
\text { enough effort to get by and keep my job }\end{array}$ & & & & & \\
\hline $\begin{array}{l}\text { c. I am one of the hardest workers in my } \\
\text { office }\end{array}$ & & & & & \\
\hline $\begin{array}{l}\text { d. I will work harder than I currently do, if I } \\
\text { worked in a private organization }\end{array}$ & & & & & \\
\hline e. I get good reviews from my supervisors & & & & & \\
\hline
\end{tabular}

Q19. It is believed that type of government in power and the type of organization that an individual works in influences the employees' work behavior. Please read the following remarks and tick the appropriate corresponding boxes that indicate whether or not you strongly agree, agree, are neutral, disagree, or strongly disagree with the statements below.

Q20. Please imagine the following scenario:

\begin{tabular}{|c|c|c|c|c|c|}
\hline & $\begin{array}{c}\text { Strongly } \\
\text { Agree } \\
\end{array}$ & Agree & Neutral & Disagree & $\begin{array}{c}\text { Strongly } \\
\text { Disagree } \\
1\end{array}$ \\
\hline a. My working style will be different if I \\
$\begin{array}{l}\text { worked in another government ministry } \\
\text { b. I don't care what party is in power, my } \\
\text { work effort and ethic will be the same. }\end{array}$ & & 4 & 3 & 2 & \\
\hline $\begin{array}{l}\text { c. It does not matter if the government is } \\
\text { democratic or military- my working style } \\
\text { does not change }\end{array}$ & & & & & \\
\hline
\end{tabular}


A public servant, who is from Accra and lives in Accra with his family and friends, is officially informed that he is to be transferred from Accra to a new post in Tamale. The public servant is from Accra and has all his friends and relatives there. The public servant is also looking after his aged parents who are too old to move to the North with him. For the above reasons, the public servant does not want to be transferred to Tamale and goes to the head of department who happens to be the cousin and requests that he be kept in Accra.

Q20A. Below are sentences that describe possible behavior of the head of department. Please circle the letter corresponding to the most likely behavior that you expect the head of department to exhibit.

a. The head of department will keep the public servant in Accra mainly because he/she is a relative.

b. The head of department will keep the public servant in Accra because the public servant has valid reasons.

c. The head of department will keep the cousin in Accra for fear of negative repercussions from family members.

d. The head of department will keep the cousin in Accra for other reasons. Please describe what other reasons:

e. The head of department will not keep the cousin in Accra and will send him to the North.

Q20B. In your view, which ONE of the following sentences BEST explains how the family members expect the head of department to behave?

a. The family will expect the head of department to help keep his cousin in Accra.

b. The family will expect head of department to follow the formal rules for transfer in deciding whether or not the public servant stays in Accra.

Q20C. In your view, which of the following sentences best captures the possible reaction of the family of the public servant if he is sent to Tamale?

a. The family will understand that the head of department had to send the cousin to Tamale.

b. The family will be a little upset that the head of department sent his cousin to Tamale.

c. The family will be very upset that the head of department sent his cousin to Tamale.

Q21. Please imagine this next scenario:

A public servant arrives at his office one morning and finds several people waiting to see him about routine business. One of these people is a relative of the public servant. The relative is not the first client to arrive.

Q21A. Please read all the sentences below and pick the statement that best captures the possible behavior of the public servant.

a. The public servant will see to his relative first.

b. The public servant will first serve the client that arrived first.

c. The public servant will see others first but will explain it to the family member so as not to upset him/her. 
Q21B. Please read all the sentences below and pick the statement that best captures what you think the family member would expect the civil servant to do?

a. The family member will expect the public servant to see him/her first.

b. The family member will expect the public servant to see to the client who arrived first.

c. The family member will expect the public servant to explain why he will have to see the client who arrived first.

Q22. Suppose that an ordinary citizen finds it necessary to go to a government official concerning ordinary official business. Which of the methods listed below would be more effective for him/her to use in order to accomplish the purpose?

a. He/she should see a relative who is also a government official.

b. He/she should go directly to the official's office and state his problem.

c. He/she should see a friend who knows the government official.

Q23. On the following list there are various aspects of a job. Please circle the one that you personally consider very important in a job.
a. Job security.
b. High income.
c. Good opportunities for advancement.
d. An interesting job.
e. A job that allows someone to help other people.
f. A job that is useful to society.

Q24. Which of the following statements best describes your feelings about your job?
a. I work only as hard as I have to.
b. I work hard, but not so as to interfere with the rest of my life.
c. I make a point of doing the best work I can, even if it sometimes interferes with the rest of my life.

Q25. Please suppose that you are advising an intelligent young man on the choice of a career. Which of the following jobs listed below would you consider for an intelligent young man? Circle your first choice.
a. Civil service
b. Professional (lawyer, doctor, engineer)
c. Accounting
d. Business
e. Skilled technician
f. Agriculturalist (modern farmer)
g. Teacher
h. Military

Q25A. If you didn't choose the civil service as a career choice for the intelligent young man, briefly state why? 
Q26. Please read the options listed below and circle which one might make you leave the public service:
a. A job offer by a large and well-established private business firm at a lower salary.
b. A job offer by a large and well-established private business firm at a higher salary.
c. A job offer by a large and well-established private business firm at the same salary.
d. I will not leave the civil service for a private business firm no matter the remuneration.

Q27. Please read the options listed below and kindly circle the option that best describes what you like about government work:
a. It provides security.
b. It provides material benefits.
c. It provides opportunity for upward mobility.
d. It provides intrinsic job satisfaction.
e. It provides the opportunity to help develop Ghana.
f. It provides services for people.
g. I don't particularly like anything about government work.

Q28. Now suppose there are two civil servants in your department. The first follows regulations exactly in every situation. The second violates regulations in those situations where he feels the achievement of the department's goals requires it. Which of the two do you think is likely to be promoted sooner, the first or the second, or do you think they both have an equal chance?

This is the end of the Survey. Thank you so much for participating. I deeply appreciate your help. 


\section{Clientele Questionnaire}

The questionnaire below is a survey about opinions of public servants and the factors affecting them as they fulfill their responsibilities. This study is part of a dissertation project to fulfill the requirements of a doctoral degree at West Virginia University, Morgantown, in the United States.

The answers you give will in no way be identified with you personally. You can remain completely anonymous. Please take a few minutes to answer the following questions. Please write responses in spaces provided. Where two or more alternates are given, please tick the appropriate answer.

R1. Gender:

R2. Age:

R3. Tribe:

R4. Please tick the highest level of Education attained by your father and mother.

\begin{tabular}{|c|l|l|}
\hline Education & Father & Mother \\
\hline a. No school & & \\
\hline b. Primary school & & \\
\hline c. Middle school & & \\
\hline d. Secondary school & & \\
\hline e. University & & \\
\hline f. Postgraduate & & \\
\hline g. Other (specify) & & \\
\hline
\end{tabular}

R5. Is your father literate in English?

(1)Yes

$(0)$ No

R6. Is your mother literate in English?

(1)Yes $(0)$ No

R7. If you are currently in a tertiary institution please tick your level. If you are not currently in a university please skip to question R8.
a.
Level 100
b.
Level 200
c.
Level 300
d. ___ Level 400

e. Other (Please Specify):

R8: Please tick your highest level of education:

\begin{tabular}{|cl|l|}
\hline h. & High school & \\
\hline i. & Polytechnic & \\
\hline j. & Bachelors & \\
\hline k. & Masters & \\
\hline l. & Doctorate & \\
\hline
\end{tabular}




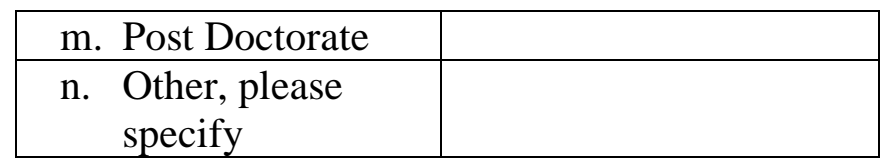

a. Yes (within Africa)

b. Yes (outside Africa)

c. No I haven't left Ghana
R9. Have you spent any time outside Ghana? Please tick all the responses that apply.

R10. Please respond to the following questions:

R10a. Are you currently working: Yes (1)

No

R10b. Are you currently working in the civil/public service?: Yes (1)

No

R10c. Have you ever worked in the public/civil service? Yes (1)

No

R11. Some Ghanaians want to work in the civil/public service while some others would prefer not to work there. Please read the following statements and tick the appropriate corresponding boxes that indicate whether or not you strongly agree, agree, are neutral, disagree, or strongly disagree with the statements below.

\begin{tabular}{|c|c|c|c|c|c|}
\hline & $\begin{array}{l}\text { Strongly } \\
\text { Agree } \\
5\end{array}$ & $\begin{array}{c}\text { Agree } \\
4 \\
\end{array}$ & $\begin{array}{c}\text { Neutral } \\
3 \\
\end{array}$ & $\begin{array}{c}\text { Disagree } \\
2\end{array}$ & $\begin{array}{l}\text { Strongly } \\
\text { Disagree } \\
1\end{array}$ \\
\hline $\begin{array}{l}\text { a. When I begin to earn a salary, I will be } \\
\text { under obligation to my family because of } \\
\text { the assistance they gave during my } \\
\text { education and upbringing }\end{array}$ & & & & & \\
\hline $\begin{array}{l}\text { b. I will like to work in the public service } \\
\text { when I graduate }\end{array}$ & & & & & \\
\hline $\begin{array}{l}\text { c. I will work in the public service if the } \\
\text { salary is good }\end{array}$ & & & & & \\
\hline $\begin{array}{l}\text { d. I will not work in the public service even } \\
\text { if the salary seems good }\end{array}$ & & & & & \\
\hline $\begin{array}{l}\text { e. My family will be upset if I worked in } \\
\text { the public service }\end{array}$ & & & & & \\
\hline
\end{tabular}

R12. Below you will find an imaginary situation presented. Please read it carefully, and then tick the corresponding box with the response that best describes your reaction to the scenario:-. 
Your father is a public servant who is posted in Accra, and he has just got notice that he will be transferred to a new post in Tamale. Your entire family lives in Accra, and if your father must move your family life will be seriously disrupted. Now, your mother's sister is married to a man who is the head of your father's department, and therefore he has the power to arrange to have your father keep his Accra post.

R12A. Please read the following statements and pick ONE that best describes how your family members will expect the head of department to behave.

c. The family will expect the head of department to help keep your father in Accra.

d. The family will expect the head of department to follow the formal rules for transfer in deciding whether or not your father stays in Accra.

R12B. In your view, which of the following sentences best captures the possible reaction of your family if your father is sent to Tamale?

d. Your family will understand that the head of department had to send your father to Tamale.

e. Your family will be a little upset that the head of department sent your father to Tamale.

f. Your family will be very upset that the head of department sent your father to Tamale.

$\mathrm{R} 13$. If you had a routine business with a government department or agency, below are listed five alternative ways of getting your business done. Which ONE of these would be the most effective, i.e. would get the business successfully completed in the shortest time?

f. You go see a friend who knows the official with whom you must deal.

g. You go straight to the government office and state your business.

h. You visit the official in charge at his house prior to going to his/her office and offer to "do something".

i. You find someone to "fix things" with the responsible official.

j. You go to the office and tip the official with whom you must deal.

R14. Please read the following statements and tick the appropriate box that best describes your perceptions of public servants and the public service

\begin{tabular}{|c|c|c|c|c|c|}
\hline & $\begin{array}{l}\text { Strongly } \\
\text { Agree } \\
5\end{array}$ & $\begin{array}{l}\text { Agree } \\
\quad 4\end{array}$ & $\begin{array}{c}\text { Neutral } \\
3\end{array}$ & $\begin{array}{l}\text { Disagree } \\
2\end{array}$ & $\begin{array}{l}\text { Strongly } \\
\text { Disagree } \\
1\end{array}$ \\
\hline $\begin{array}{l}\text { a. Government officials are cooperative and } \\
\text { courteous }\end{array}$ & & & & & \\
\hline $\begin{array}{l}\text { b. Public officials care about what people } \\
\text { like me think }\end{array}$ & & & & & \\
\hline $\begin{array}{l}\text { c. Government employees are dedicated to } \\
\text { serving the public and to the development } \\
\text { of the country }\end{array}$ & & & & & \\
\hline $\begin{array}{l}\text { d. The ordinary citizen can impact the way } \\
\text { public servants perform }\end{array}$ & & & & & \\
\hline
\end{tabular}




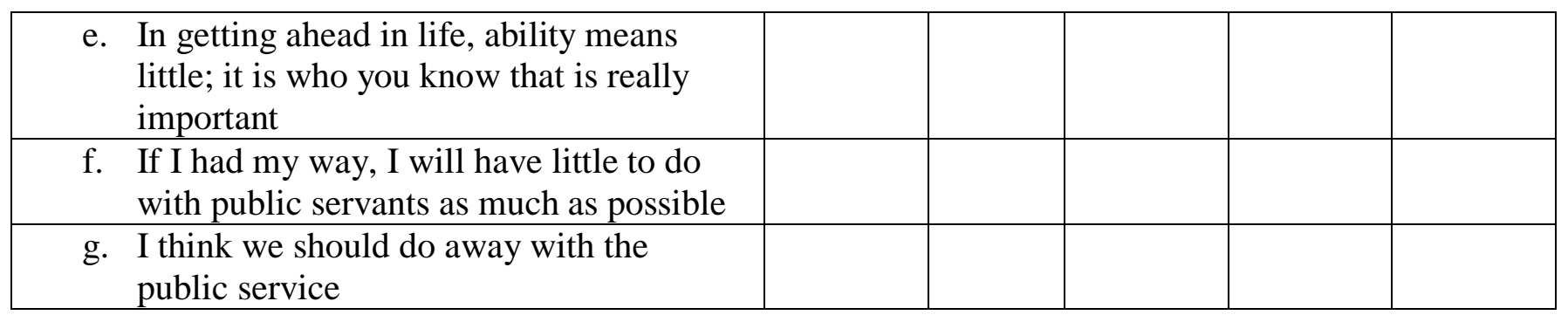

R15. Below are descriptions of two senior government officials. Please circle the letter by the statement that describes the official you think is the better man.

a. Official One: He has used his official position to "chop" a great deal of money, but he has shown great generosity, coming to the aid of any of his people who are in need.

b. Official Two: He follows all rules and regulations of his office and has not "chopped" money, but as a result, although he would like to show generosity, he constantly refuses to help any of his people who are in need.

c. Which of the two above officials do you think most Ghanaians would consider the better man?

d. Which of the two would you prefer as a relative?

R16. Suppose that you were teaching a child how to deal with the government civil service. Which of these three ways would you tell him to use when approaching civil servants for help?

d) As a government employee, he is your servant, and it is his duty to give you prompt help. You should simply state what you want from him.

e) He is in a position of authority and therefore you must show proper respect if you expect help from him.

f) Although civil servants are employed to serve people like you, it is best to show respect if one wants help from them

R17. I would like to know, in your point of view, what kinds of people are respected in Ghana. Descriptions of seven people are listed below. Please write the number 1 by the one you believe is likely to be most respected by Ghanaians and write the number 2 by the one you believe is the next most respected individual.

a) $\mathrm{He} / \mathrm{she}$ earns a high salary.

b) $\mathrm{He} / \mathrm{she}$ is liked by the people with whom he/she works.

c) $\mathrm{He} / \mathrm{she}$ is able to take care of his/her relatives and friends should they be in need.

d) $\mathrm{He} / \mathrm{she}$ has all the good things in life: a good car, a big house, fine clothing etc.

e) $\mathrm{He} / \mathrm{she}$ is better at the duty than anyone else.

f) $\mathrm{He} / \mathrm{she}$ holds a position in which he/she has many subordinates who must obey orders.

g) $\mathrm{He} / \mathrm{she}$ makes a contribution to the development of Ghana. 
R18. Some people say that knowing a "big man" in government plays an important part in whether the government will help a private citizen with some problems he has; other people say that this is not so. In your opinion, does knowing a "big man" play an important part in whether the government will help a private citizen?
a) Yes, a very important part.
b) Yes, a somewhat important part.
c) No, not a very important part.
d) No, no part at all.

R19. Finally, would you please read the statement below and rate the performance of the Public Service?

\begin{tabular}{|l|c|c|c|c|c|}
\hline & $\begin{array}{c}\text { Exceedingly } \\
\text { High } \\
5\end{array}$ & 4 & 3 & 2 & $\begin{array}{c}\text { High } \\
\text { Low } \\
1\end{array}$ \\
\hline $\begin{array}{l}\text { If you were asked to give an efficiency } \\
\text { rating of the Ghanaian Public Service, } \\
\text { which of the following ratings would you } \\
\text { give? Efficiency is:- }\end{array}$ & & & & & \\
\hline
\end{tabular}

Thank you so much for taking part in this survey. I sincerely appreciate your effort. 


\section{Comparison/Clientele Interview}

The questionnaire below is a survey about opinions of public servants and the factors affecting them as they fulfill their responsibilities. This study is part of a dissertation project to fulfill the requirements of a doctoral degree at West Virginia University, Morgantown, in the United States.

The answers you give will in no way be identified with you personally. You can remain completely anonymous. Please take a few minutes to answer the following questions. The interviewer will read you the questions and will tick the boxes corresponding to your responses.

S1. Gender:

S2. Age:

S3. Tribe:

S4. To be filled by interviewer. How well can respondent speak English?

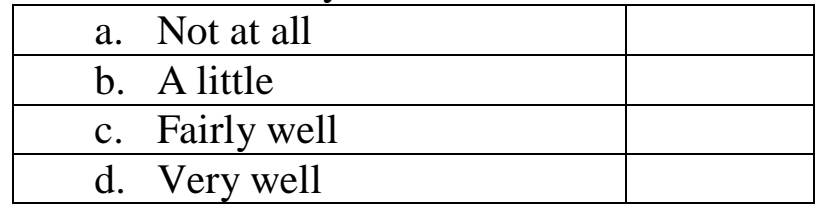

S5. What is the highest Level of Education attained by your parents?

\begin{tabular}{|l|l|l|}
\hline a. No school & Father & Mother \\
\hline b. Primary school & & \\
\hline c. Middle school & & \\
\hline d. Secondary school & & \\
\hline e. University & & \\
\hline f. Postgraduate & & \\
\hline g. Other (specify) & & \\
\hline
\end{tabular}

S6. Is your father literate in English?

(1) Yes (0)No

S7. Is your mother literate in English?

(1)Yes $(0) \mathrm{No}$

S8. Where do you live?

S9. What work do you do? 
Now we turn to the main part of the questionnaire, which deals with the relations of citizens to government departments, agencies and ministries.

S10. In the set of questions following, Imagine that you went to a government agency to get some matters taken care off. Please tell me which of the following statements you believe best describes the treatment you would receive from the public servant that is handling the matter.

a. You will receive better treatment because the Public servant is your close friend.

b. You will receive better treatment because the Public servant is your uncle.

c. You will receive better treatment because the Public servant is from your tribe

d. You will receive better treatment because the public servant is doing his duty.

S11. Suppose you had to go to a government office to take care of some routine business. The business should take only a few minutes to transact, but you find yourself waiting three hours. Then the government official calls you over and simply says "go and come"

What would be your likely reaction to this situation? Tell me which of the following statements comes close to your probable reaction.

e. I would realize that "this is the way things are," that it is to be expected, and I would come back the next day.

f. I would become angry and demand an explanation from the civil servant.

g. Becoming angry, I would demand that the civil servant serve me, and if he did not I would insist on seeing his superior or supervisor.

h. I would offer to "do something" if he would finish the business straight away.

S12. I will read you some descriptions of two senior government officials. Please let me know, in your opinion which statement best describes the official you think is the better man.

e. Official One. He has used his official position to "chop" a great deal of money, but he has shown great generosity, coming to the aid of any of his people who are in need.

f. Official Two. He follows all rules and regulations of his office and has not "chopped" money, but as a result, although he would like to show generosity, he constantly refuses to help any of his people who are in need.

g. Which of the two above officials do you think most Ghanaians would consider the better man?

h. Which of the two would you prefer as a relative?

S13. If you had a routine business with a government department or agency, below are listed five alternative ways of getting your business done. Which of these would be the most effective, i.e. would get the business successfully completed in the shortest time? 
a) You go see a friend who knows the official with whom you must deal

b) You go straight to the government office and state your business.

c) You visit the official in charge at his house prior to going to his/her office and offer to "do something"

d) You find someone to "fix things" with the responsible official

e) You go to the office and tip the official with whom you must deal

S14. I will describe an imaginary situation to you after which I will ask you some questions.

Your father is a public servant who is posted in Accra, and he has just got notice that he will be transferred to a new post in Tamale. Your entire family lives in Accra, and if your father must move your family life will be seriously disrupted. Now, your mother's sister is married to a man who is the head of your father's department, and therefore he has the power to arrange to have your father keep his Accra post.

S14A. Which of the following statements best describes how your family members will expect the head of department to behave?

e. The family will expect the head of department to help keep your father in Accra.

f. The family will expect the head of department to follow the formal rules for transfer in deciding whether or not your father stays in Accra.

S14B. In your view, which of the following sentences best captures the possible reaction of your family if your father is sent to Tamale?

g. Your family will understand that the head of department had to send your father to Tamale.

h. Your family will be a little upset that the head of department sent your father to Tamale.

i. Your family will be very upset that the head of department sent your father to Tamale.

S15. I would like to know, in your point of view, what kinds of people are respected in Ghana? I will read the descriptions of seven people. Please tell me the one you believe is likely to be most respected by Ghanaians. Also tell me who you think is the next most respected individual in Ghana.

h) $\mathrm{He} / \mathrm{she}$ earns a high salary.

i) He/she is liked by the people with whom he/she works.

j) He/she is able to take care of his/her relatives and friends should they be in need.

k) He/she has all the good things in life: a good car, a big house, fine clothing etc.

1) $\mathrm{He} / \mathrm{she}$ is better at the work than anyone else.

m) He/she holds a position in which he/she has many subordinates who must obey orders.

n) $\mathrm{He} / \mathrm{she}$ makes a contribution to the development of Ghana.

S16. Suppose that you were teaching a child how to deal with the government civil service. Which of these three ways would you tell him to use when approaching civil servants for help? 
g) As a government employee, he is your servant, and it is his duty to give you prompt help. You should simply state what you want from him.

h) He is in a position of authority and therefore you must show proper respect if you expect help from him.

i) Although civil servants are employed to serve people like you, it is best to show respect if one wants help from them

S17. Some people say that knowing a "big man" in government plays an important part in whether the government will help a private citizen with some problems he has; other people say that this is not so. In your opinion, does knowing a "big man" play an important part in whether the government will help a private citizen?

e) Yes, a very important part.

f) Yes, a somewhat important part.

g) No, not a very important part.

h) No, no part at all.

S18. I will read you some statements and would like you to let me know whether you strongly agree, agree, are neutral, disagree or strongly disagree with them.

\begin{tabular}{|c|c|c|c|c|c|}
\hline & $\begin{array}{l}\text { Strongly } \\
\text { Agree }\end{array}$ & Agree & Neutral & Disagree & $\begin{array}{l}\text { Strongly } \\
\text { Disagree }\end{array}$ \\
\hline $\begin{array}{l}\text { a. Government officials are cooperative and } \\
\text { courteous }\end{array}$ & & & & & \\
\hline $\begin{array}{l}\text { b. Public officials care about what people } \\
\text { like me think }\end{array}$ & & & & & \\
\hline $\begin{array}{l}\text { c. Government employees are dedicated to } \\
\text { serving the public and to the development } \\
\text { of the country }\end{array}$ & & & & & \\
\hline $\begin{array}{l}\text { d. The ordinary citizen can impact the way } \\
\text { public servants perform }\end{array}$ & & & & & \\
\hline $\begin{array}{l}\text { e. In getting ahead in life, ability means } \\
\text { little; it is who you know that is really } \\
\text { important }\end{array}$ & & & & & \\
\hline $\begin{array}{l}\text { f. If I had my way, I will have little to do } \\
\text { with public servants as much as possible }\end{array}$ & & & & & \\
\hline $\begin{array}{l}\text { g. I think we should do away with the } \\
\text { public service }\end{array}$ & & & & & \\
\hline
\end{tabular}

S19. Finally, how would you rate the performance of the Public Service?

\begin{tabular}{|l|l|l|l|l|l|}
\hline & $\begin{array}{l}\text { Exceedingly } \\
\text { High }\end{array}$ & High & Average & Low & $\begin{array}{l}\text { Exceedingly } \\
\text { Low }\end{array}$ \\
\hline $\begin{array}{l}\text { If you were asked to give an efficiency } \\
\text { rating of the Ghanaian Public Service, } \\
\text { which of the following ratings would you } \\
\text { give? Efficiency is }\end{array}$ & & & & & \\
\hline
\end{tabular}

This is the end of the Survey. Thank you so much for participating. I deeply appreciate your help. 